\title{
Nanomaterials for application in wound Healing: current state-of-the-art and future perspectives
}

\author{
Manal Aly Shalaby ${ }^{1,2} \cdot$ Mohammed Moustapha Anwar $^{3}\left(\mathbb{D} \cdot\right.$ Hesham Saeed $^{3}$
}

Received: 22 May 2021 / Accepted: 14 December 2021 / Published online: 19 February 2022

(c) The Author(s) 2022

\begin{abstract}
Nanoparticles are the gateway to the new era in drug delivery of biocompatible agents. Several products have emerged from nanomaterials in quest of developing practical wound healing dressings that are nonantigenic, antishear stress, and gas-exchange permeable. Numerous studies have isolated and characterised various wound healing nanomaterials and nanoproducts. The electrospinning of natural and synthetic materials produces fine products that can be mixed with other wound healing medications and herbs. Various produced nanomaterials are highly influential in wound healing experimental models and can be used commercially as well. This article reviewed the current state-of-the-art and briefly specified the future concerns regarding the different systems of nanomaterials in wound healing (i.e., inorganic nanomaterials, organic and hybrid nanomaterials, and nanofibers). This review may be a comprehensive guidance to help health care professionals identify the proper wound healing materials to avoid the usual wound complications.
\end{abstract}

Keywords Electrospinning $\cdot$ Nanomaterials $\cdot$ Wound healing

\section{Introduction}

Nanomaterial-based wound healing is a significant tool that treats and prevents wound infections with diverse advantages versus standard-of-care (SOC) [1]. Wounds are the "silent

\section{Key points}

- Tailored wound nanobandages as well as inorganic/natural polymer/antibiotic-based nanocomposites in combination with biomolecules and growth factors, may be a successful strategy in wound healing.

- International health guidelines should consider the high cost, structural defects, physical stability, mechanical durability, and toxicity of the synthesised nanoparticles for wound healing.

Mohammed Moustapha Anwar

igsr.dr.mohamedanwar@alexu.edu.eg

1 Medical Biotechnology Department, Institute of Genetic Engineering, City of Scientific Research and Technological Applications, Alexandria, Egypt

2 Centre of Excellence for Drug Preclinical studies (CE-DPS) Pharmaceutical and Fermentation Industry Development Centre, City of Scientific Research and Technological Applications, New Borg El Arab, Alexandria, Egypt

3 Department of Biotechnology, Institute of Graduate Studies and Research (IGSR), Alexandria University, Alexandria, Egypt epidemic" that impairs the patients' quality-of-life (QoL) [2]. In 2018, an economic analysis of acute and chronic wounds showed that around eight million beneficiaries suffered from $\geq 1$ type of wound or related infection [3]. Ideal wound dressings are exudate-absorbents with high swelling capacity and porosity, good water vapour transmission rate (WVTR), antibacterial, and antiinflammatory properties. They show excellent elasticity and flexibility, drug loading capacity, tensile strength, spreadability, and provide a moist wound environment that accelerates healing, but most of the available dressings do not have some of these characteristics [4-7]. Table 1 lists the currently used dressings with their advantages and disadvantages in wound healing $[8,9]$. Conventional wound care (e.g., herbal medicines, honey, bandages, and dressings) leaves scars regardless of the aesthetical as well as the plausible functional modifications [10-12].

Honey exhibits interesting immunostimulatory, antimicrobial, antioxidant, and antiinflammatory actions in wound healing (Table 1) [13]. However, honey displays some disadvantages or adverse effects upon its topical use in wounds. For example, honey-impregnated dressings may be hard to prepare; high temperatures make it more fluid; transient stinging sensation may occur; it may increase the blood glucose concentration in diabetic patients at large wounded areas; excessive application may dehydrate tissues; and 


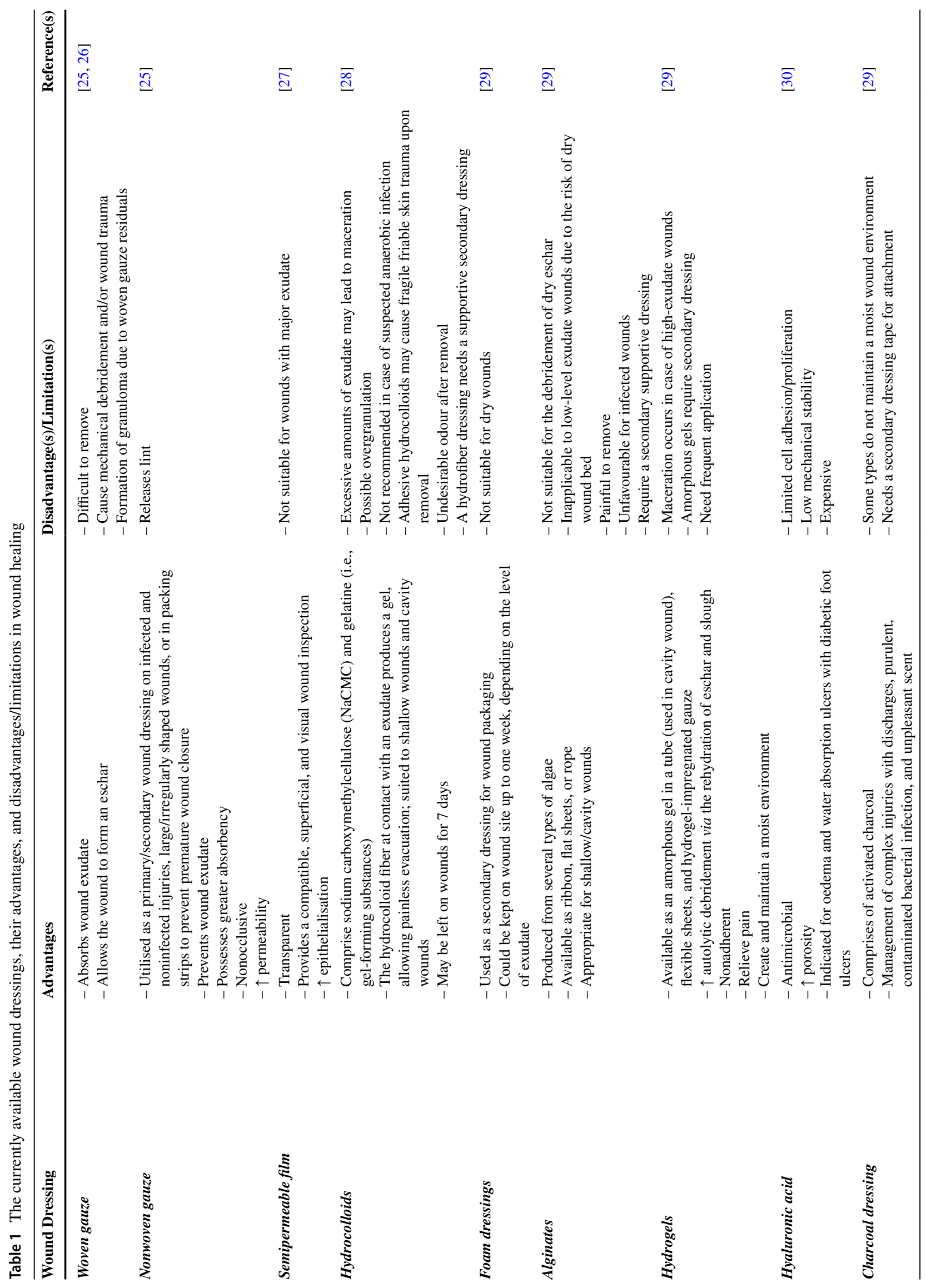




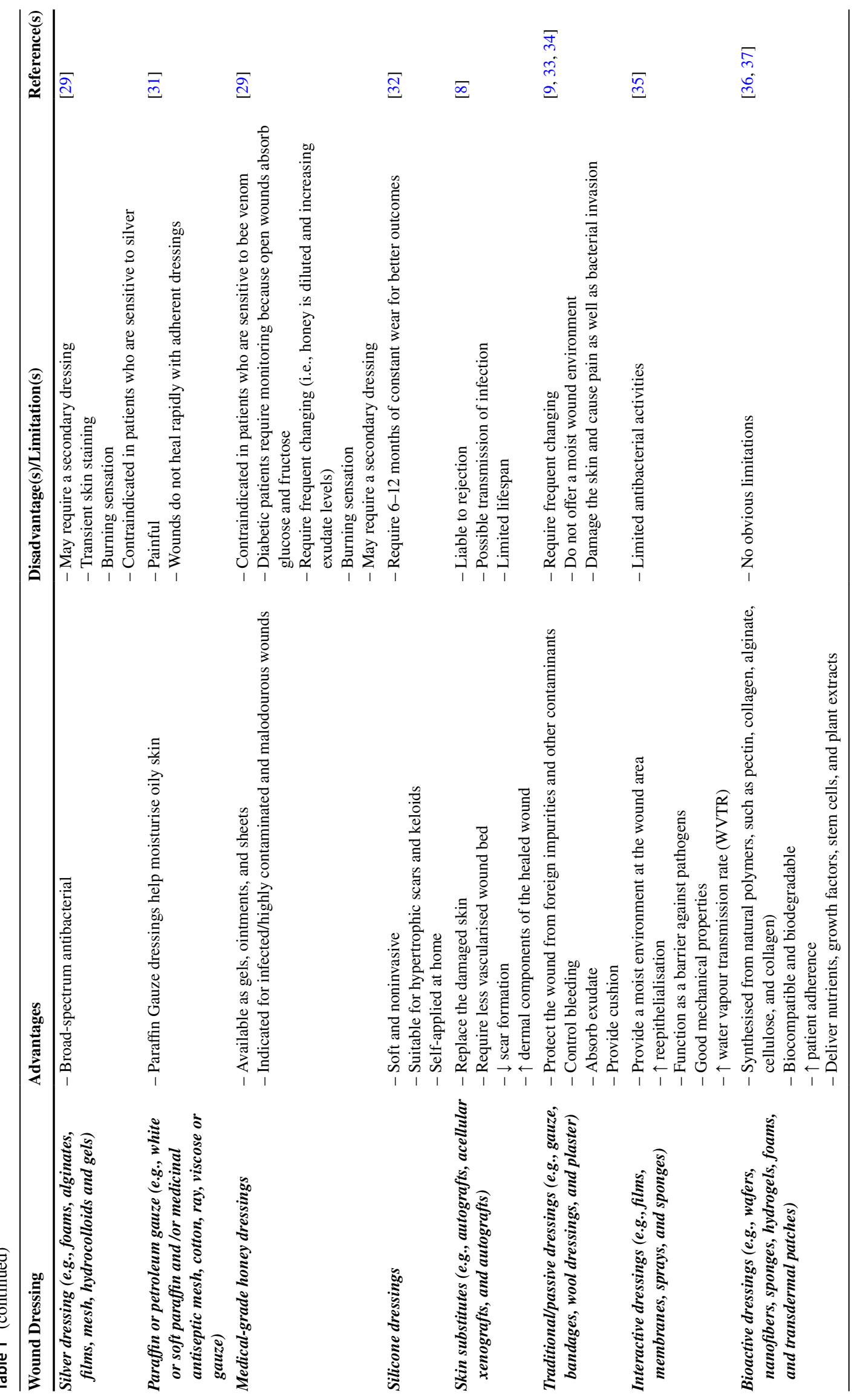


pollen/bee proteins in the honey may lead to hypersensitivity [14-16]. Limitations to these traditional materials besides restitutio ad integrum (i.e., the delay of tissue integrity restoration) aggravate wounds, especially chronic wounds [17]. Therefore, potential wound healing materials would boost the clinical outcomes [18].

Innovative polymeric nanofibers, polymeric nanoscaffolds, and nanoceria have emerged in the management of wound healing [19, 20]. Nanomaterials of natural origin and drug delivery vehicles are fit for cellular responses, penetrability, and active drug delivery in wound healing because of the high surface area-to-volume ratios and their nano size $[21,22]$. Biocellulose functionalised with silver nanoparticles (AgNPs) act as an effective coating against Gramnegative bacteria and accelerate open wound healing [23]. Silver nanoparticle-coated polyester-nylon dressings were highly biocompatible, showed antibacterial efficacy, facilitated the normal development of human cells in-vitro, and exhibited a normal biodistribution with low toxicity in-vivo [24]. The currently available reviews may have focused only on one or two nanotechnology systems in wound healing (e.g., diabetic ulcers). Herein, we outline the different systems of nanomaterials in wound healing (i.e., inorganic nanomaterials, organic and hybrid nanomaterials, and nanofibers) (Fig. 1). We also shed light on the main concerns regarding the future use of nanomaterials in wound healing.

\section{Inorganic/organic nanocomposites in wound healing}

Inorganic/organic nanocomposite scaffolds have lured attention because of displaying unique antibacterial and mechanical properties upon blending an inorganic nanoparticle with a supporting polymer matrix (Table 2) [38,
39]. Inorganic/organic nanocomposites have met the increasing demands of wound healing due to their nature, their inorganic/organic material ratio, and the size and distribution of the inorganic nanoparticles in the polymer matrices [40]. For example, the intermediate-modified gold nanoparticles (AuNPs) combined with polycaprolactone (PCL)/gelatin nanofibers are active against multidrug resistant (MDR) bacteria in-vivo [41]. Electrospun scaffolds of copper sulfide $\left(\mathrm{Cu}_{2} \mathrm{~S}\right)$ nanoparticles with polylactic acid (PLA)/PCL polymers heal diabetic full-thickness skin wounds and significantly stimulated angiogenesis in-vivo [40].

Natural (e.g., dextran, chitosan, and alginates) and synthetic polymers (e.g., poly[ $\varepsilon$-caprolactone] and poly[acrylic acid] [PAA]) are utilised to fabricate skin tissue engineering scaffolds [53-55]. While natural polymers are biocompatible and enzymatically biodegradable, their strength is inadequate, and they exhibit uncontrolled degradability. The structural, mechanical as well as the chemical properties of synthetic polymers are controllable. However, low biocompatibility, limited ability to promote wound healing, loss of mechanical properties, and the production of toxic products during degradation, limit their application in wound management $[40,53,56,57]$.

\section{Inorganic nanoparticles and nanocomposites in wound healing}

Attractive bionanocomposites incorporate a range of inorganic nanomaterials (e.g., carbon-based nanoparticles, metal and metal oxide nanomaterials, and ceramic nanoparticles) that have promising bioactive, mechanical, and bactericidal characteristics to accelerate wound healing (Table 3) [58]. Such criteria are based on surface charge and functionalisation, polydispersity index (PDI), dimension, and architecture.
Fig. 1 A schematic representation of the discussed nanoparticles and nanofibers in the current review article

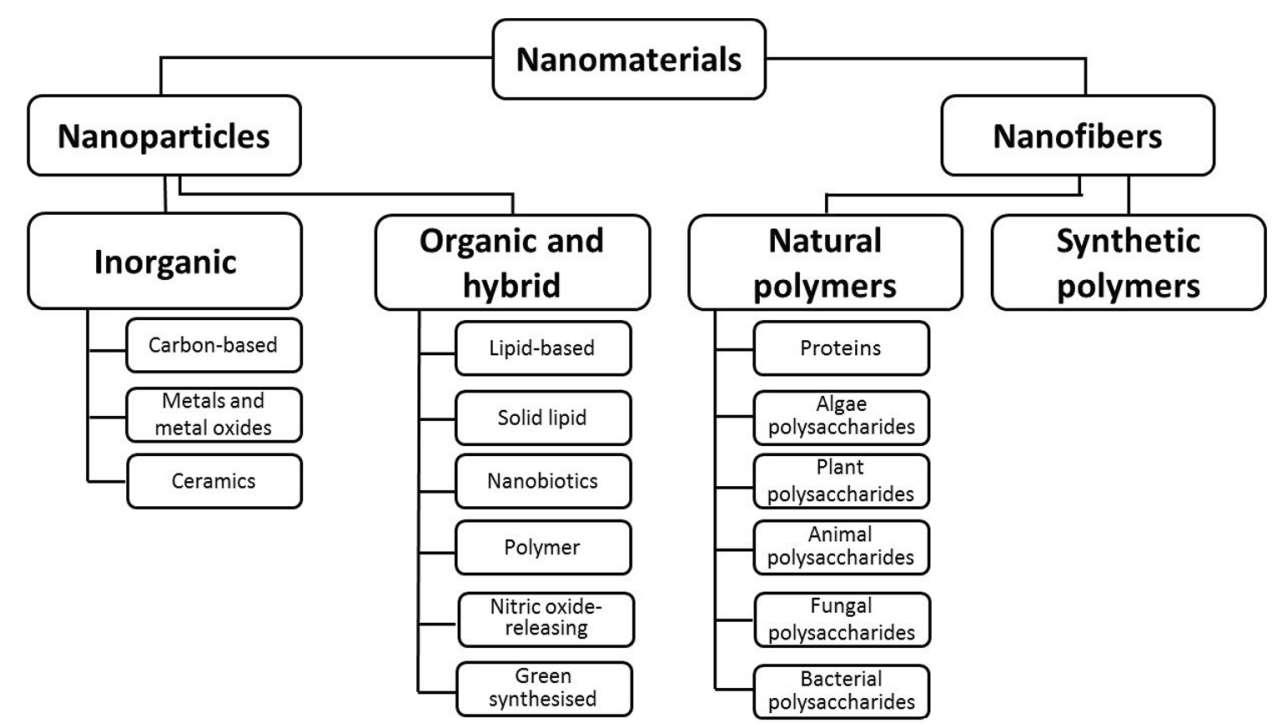


Table 2 Examples of inorganic/organic nanocomposites in wound healing

\begin{tabular}{lll}
\hline Inorganic/Organic Nanocomposite & Reference \\
\hline Polymer-based silver nanoparticles (AgNPs) & {$[42]$} \\
Polypropylene-G-poly(ethylene glycol) comb-type graft copolymers containing gold nanoparticles (AuNPs) & {$[43]$} \\
Poly-propylene polyethylene glycol (PPEG) membranes impregnated with Au and Au cobalt oxide nanoparticles (AuCoONPs) & {$[44]$} & {$[45]$} \\
Poly (3-hydroxy octanoate-co-3-hydroxy-10-undecenoate) (PHOU)-encapsulated Au clusters & {$[46]$} \\
Silver nanoparticles mixed with polypropylene-g-PEG (PP-g-PEG) & {$[47]$} \\
Iodinated poly-3-hydroxy butyrate (PHB) & {$[48]$} \\
AuNPs incorporated into the autooxidised soybean oil polymer & {$[49]$} \\
PLinaS-g-PEG-coating of magnetic iron oxide nanoparticles & {$[50]$} \\
AuNPs and CoONPs embedded into PP-g-PEG & {$[51]$} \\
AuNPs mixed with acrylic resins & {$[52]$} \\
AuNPs-embedded poly(propylene-co-imidazole) & \\
\hline
\end{tabular}

Therefore, combining different inorganic nanoparticles would lead to desirable therapeutic effects [59].

\section{Carbon-based nanomaterials}

Carbon-based nanomaterials (two-dimensional graphene, onedimensional carbon nanotubes, zero-dimensional-structure fullerene, nanodiamonds, and diamond-like carbon) are involved in the four wound healing phases and are able to deliver antibiotics, antioxidants, growth factors or stem cells [60-64]. Carbon-based nanomaterials are used in tissue engineering, targeted drug delivery, and skin care due to their physicochemical properties and large surface area $[63,65]$. The production of reactive oxygen species (ROS) in addition to the hydrophobic nature of carbon nanomaterials are responsible for their inherent antimicrobial activity [66-72].

\section{(a) Graphene}

Graphene oxide, graphite oxide, graphite, and reduced graphene oxide nanofilms have excellent antibacterial activities [73-76]. Graphene and graphene oxide strongly induce ROS-independent oxidative stress when interacting with bacteria [76-78]. In graphene, the arrangement of carbon atoms generates electrons that move to the cells of the microorganisms due to the potential of the cell membrane [79]. The graphene oxide nanofilm enriched with epoxy coating had higher biocompatibility, accelerated infected wound healing in mice, and killed Staphylococcus aureus ( $S$. aureus) and Escherichia coli (E. coli) [80]. Graphene oxide with laser enhanced the healing of fungal and bacterial wound infections (Table 3) [63, 65, 81].

Chitosan-coated electrospun nanofibers are rising as materials for drug release, tissue engineering, and wound healing [82-87]. Chitosan-polyvinyl alcohol (PVA) nanofibers containing graphene impeded the proliferation of E. coli and Agrobacterium cells but not yeast, by disrupting the DNA structure or other genetic material in mice and Van Beveren rabbits [79]. Graphene oxide/copper $(\mathrm{Cu})$-incorporated chitosan/ hyaluronic acid composite significantly accelerated the healing of intractable bacterial wound infections with acceptable biocompatibility in-vitro and in-vivo [88]. Graphene dressing scaffolds-mesenchymal stem cell combination enhanced cutaneous wound healing and infection control via chemical and mechanical stimuli [89]. Notwithstanding these advantages, structural defects that occur during the production of graphene (e.g., hexagons that transform into pentagons and single/multiple vacancies) influence its intrinsic properties and therapeutic effects [90, 91].

\section{(b) Carbon nanotubes}

Single-walled and multiwalled carbon nanotubes significantly affect the bacterial membrane integrity, metabolic activity, and morphology via ROS and heavy metal residues [92-97]. Particularly, single-walled nanotubes show a higher antibacterial activity than multiwalled nanotubes because of their smaller size that provides a larger surface area and disturbs the bacterial membrane. A recent in-vitro study revealed that carbon nanotubemercury composite has treated burn-related infections with significant antibacterial action against different Acinetobacter baumannii (A. baumannii) species. The carbon nanotube-mercury composite also increased the mRNA expression levels of platelet-derived growth factor (PDGF), epidermal growth factor (EGF), and vascular endothelial growth factor A (VEGF) that are considered as wound healing factors [98]. Combinations of carbon nanotubes with AgNPs and titanium dioxide nanoparticles $\left(\mathrm{TiO}_{2} \mathrm{NPs}\right)$ had higher antibacterial effect [99, 100]. Hydroxyl functionalised single-walled nanotubes posed an elevated antibacterial activity on Paracoccus denitrificans (P. denitrificants) [101]. Chitosan 


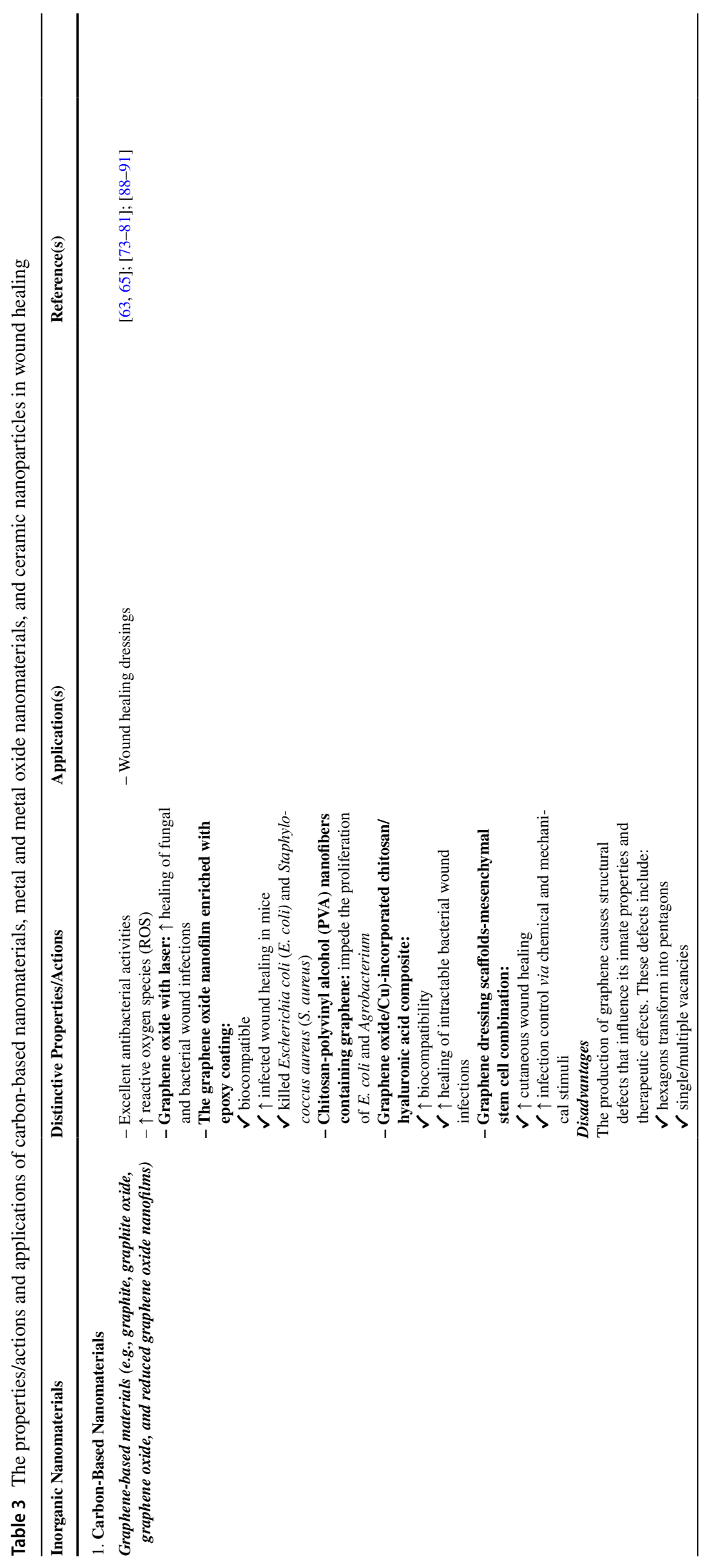




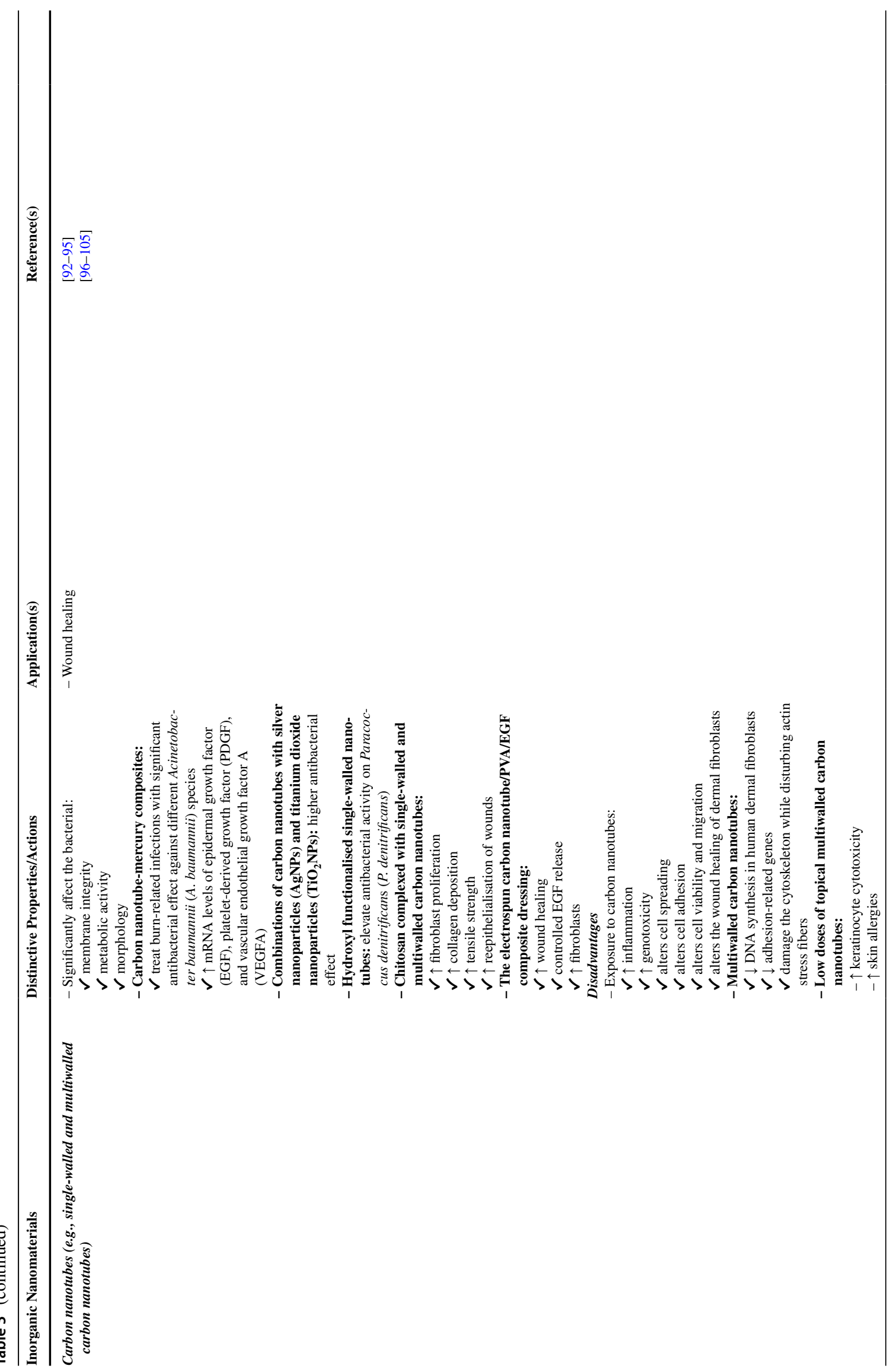




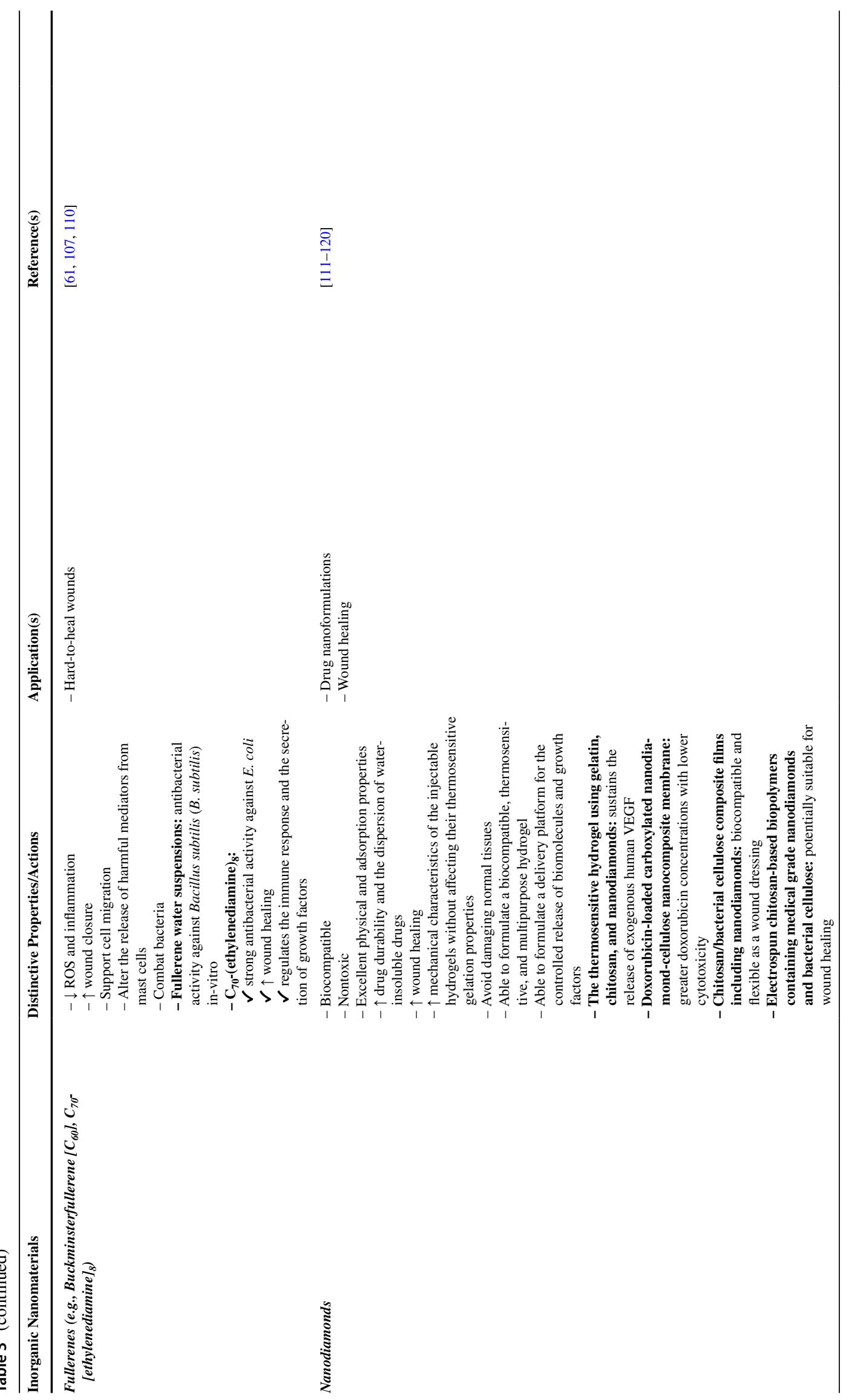

Springer 


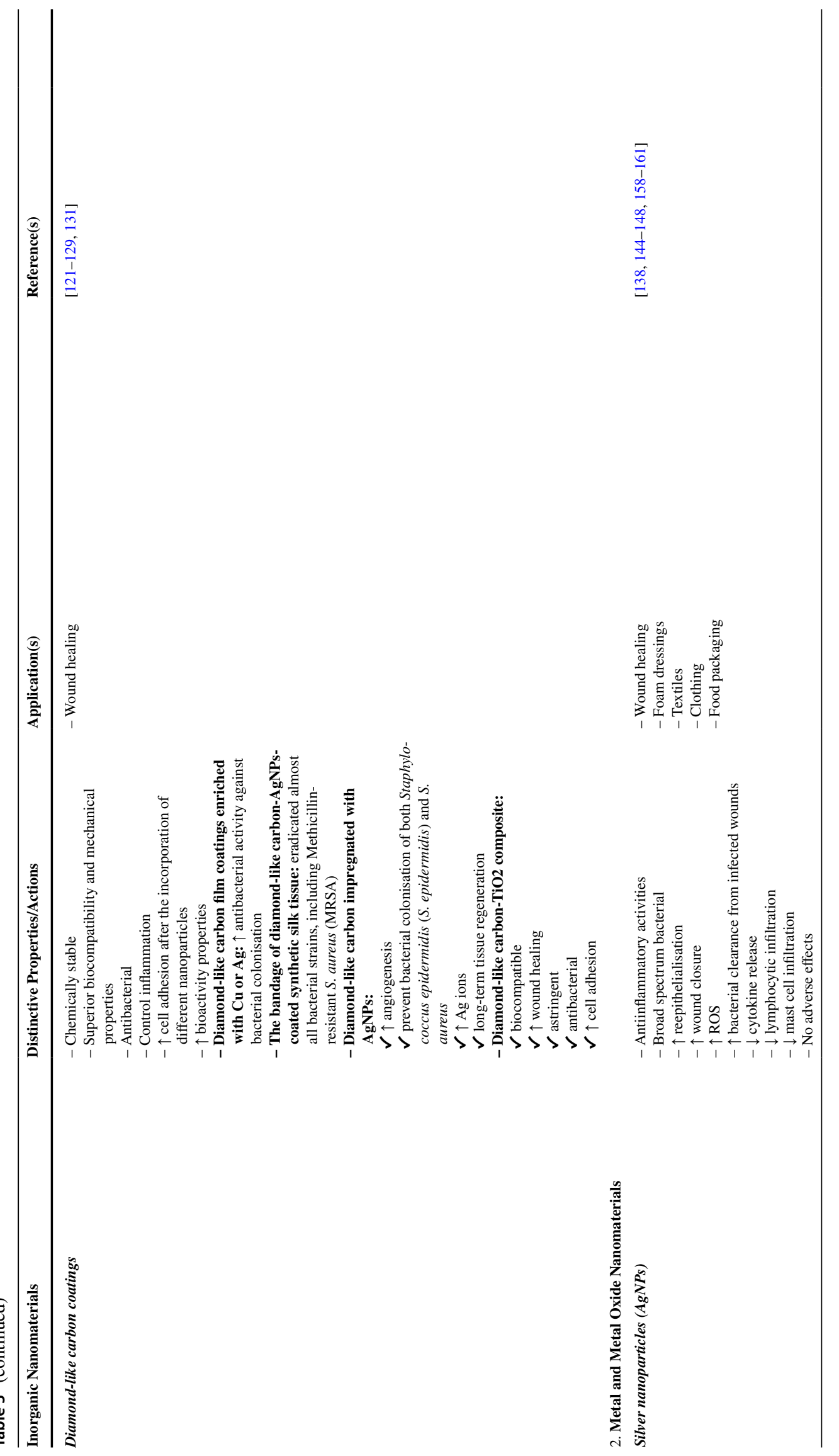


91 Page 10 of 37

Journal of Polymer Research (2022) 29: 91

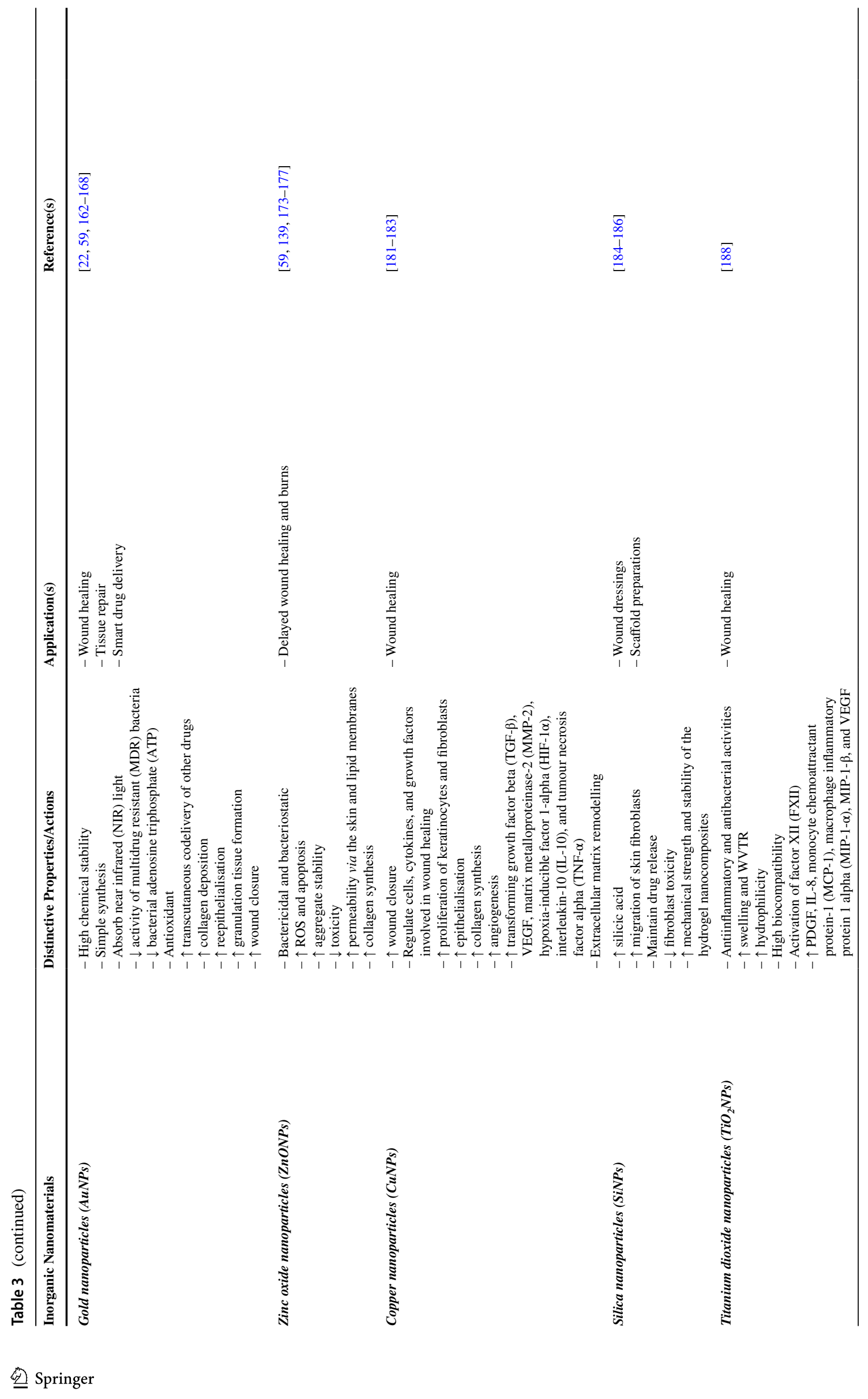




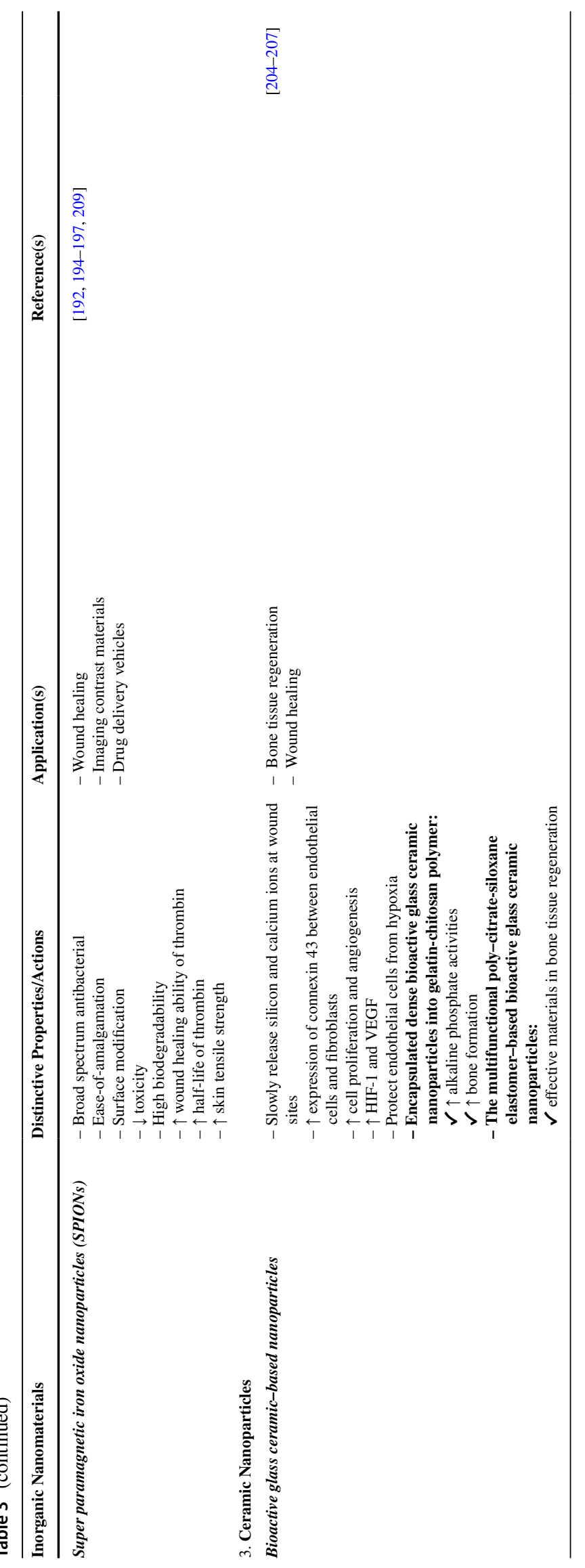


complexed with single-walled and multiwalled carbon nanotubes improved the tensile strength, deposition of collagen, proliferation of fibroblast, and the reepithelialisation of wounds, but with an increase in fibrosis in-vitro and in-vivo [97]. The electrospun carbon nanotube/PVA/ EGF composite dressing accelerated wound healing invitro and in-vivo and displayed a controlled release of EGF with favourable activity to accelerate the growth of fibroblasts (Table 3) [102].

Exposure to carbon nanotubes induces inflammation and genotoxicity and affects the wound healing of dermal fibroblasts by altering cell spreading, adhesion, migration, and viability [103]. Multiwalled carbon nanotubes inhibited DNA synthesis and the levels of adhesion-related genes while damaging the cytoskeleton and disturbing actin stress fibers simultaneously in both NIH 3T3 murine fibroblasts and human dermal fibroblasts [104]. Low doses of topical multiwalled carbon nanotubes also induced keratinocyte cytotoxicity and aggravate skin allergies [105].

\section{(c) Fullerenes}

Fullerenes and their derivatives may target hard-to-heal wounds by reducing inflammation, combating bacteria, altering the release of harmful mediators from mast cells, supporting cell migration, and accelerating wound closure (Table 3) [61]. Fullerene water suspensions are adsorbed on the bacterial membranes of Bacillus subtilis (B. subtilis) and initiate ROS-independent oxidative stress in-vitro [106-109]. Buckminsterfullerene (known as $\mathrm{C}_{60}$ ) - the most studied fullerene-is strongly hydrophobic and marginally water-soluble [106]. The fullerene derivative $\mathrm{C}_{70}$-(ethylenediamine) $)_{8}$ significantly inhibited $E$. coli and controlled the immune defense as well as the production of growth factors, accelerating wound healing in-vivo [110]. The amino groups on the ethylenediamine moiety form electrostatic interactions on the outer bacterial membrane, whereas the inner membrane strongly interacts with the $\mathrm{C}_{70}$ hydrophobic surface via hydrophobic interactions, triggering cytoplast leakage [110].

\section{(d) Nanodiamonds}

Nanodiamonds are attractive for drug nanoformulations because they are small in size, biocompatible and nontoxic, possess excellent physical and adsorption properties, improve the durability of drugs, and facilitate the dispersion of water-insoluble drugs (Table 3) [111-115]. Nanodiamonds also accelerate wound healing while protecting normal cells/tissues [116]. They have the potential to formulate a thermosensitive, biocompatible, multipurpose hydrogel platform, and other systems for the delivery of controlled release growth factors and biomolecules. Nanodiamonds improve the mechanical characteristics of the injectable hydrogels without affecting its thermosensitive gelation properties. For instance, the thermosensitive hydrogel using gelatin, chitosan, and nanodiamonds sustains the release of exogenous human VEGF [117]. Doxorubicin-loaded carboxylated nanodiamond-cellulose nanocomposite membrane exhibited greater doxorubicin concentrations with lower cytotoxicity in-vitro [118]. The chitosan/bacterial cellulose composite films including nanodiamonds were biocompatible and flexible as a wound dressing [119]. The electrospun chitosan-based biopolymers containing medical grade nanodiamonds and bacterial cellulose also were suitable for wound healing [120].

\section{(e) Diamond-like carbon coating}

Diamond-like carbon film carbon coatings are chemically stable and exhibit superior biocompatibility, mechanical properties, and antibacterial efficacy due to their hydrophobic nature that alters the cell membrane, causing bacterial death [121-125]. Diamondlike carbon controls inflammation, enhances bioactivity properties and cell adhesion, and reduces the attachment and growth of bacteria [126-128]. Diamondlike carbon film coatings enriched with toxic elements (e.g., $\mathrm{Ag}$ or $\mathrm{Cu}$ ) possess higher antibacterial activity against bacterial colonies (e.g., Staphylococcus epidermidis [S. epidermidis] and S. aureus) that increase the risk of life-threatening bacteraemia [129-131]. The bandage of diamond-like carbon-AgNPs-coated synthetic silk tissue killed almost $100 \%$ of all bacterial strains, including methicillin-resistant $S$. aureus (MRSA) [132]. The diamond-like carbon impregnated with AgNPs activated angiogenesis and prevented bacterial colonisation of both S. epidermidis and S. aureus due to the rapid $\mathrm{Ag}$ ion release, allowing long-term tissue regeneration in-vitro [133]. The diamond-like carbon$\mathrm{TiO}_{2}$ composite was biocompatible, increased cell attachment, and improved wound healing in-vivo due to its astringent and antibacterial actions (Table 3) [134].

\section{Metals and metal oxide nanomaterials}

Compared with the traditional wound healing agents (i.e., plant extracts, honey, and larvae), metal and metal oxide nanomaterials are more favourable because they possess better intrinsic qualities, such as catalytic, optical, and melting properties [135]. The nano size and shape, surface properties, porosity, and the ability of metals to resist 
decomposition in aqueous solutions, contribute to their efficacy in biological applications [59, 136, 137]. Zinc oxide $(\mathrm{ZnO}), \mathrm{Au}, \mathrm{Ag}$, and $\mathrm{CuO}$ have interesting physicochemical (e.g., lower melting points) and antibacterial properties due to their small size [138, 139]. Gold and Ag are famous by their unique 'Surface Plasmon Resonance (SPR)' propertya resonant oscillation of conductive electrons on the metal film when excited by a polarised light - that is controlled by the composition, shape, and size of nanoparticles. Surfaceenhanced Raman spectroscopy (SERS), biomedicine, and photocatalysis as well as photothermal therapy gave much attention to the SPR phenomenon [140-143].

\section{(a) Silver nanoparticles (AgNPs)}

Metal-based nanoparticles such as AgNPs have wide medical and commercial applications. Other commercially available and daily products comprise AgNPs include: Aquacel Ag and CuraFoam AG Silver Foam dressings, textiles, clothing, and food packaging [138, $144,145]$. Silver nanoparticles have gained deep interests for wound healing applications due to their distinctive physicochemical, antibacterial, and antiinflammatory properties [146]. Silver nanoparticles enhance wound healing by reducing the release of cytokines, mast cell infiltration, and lymphocytes [147, 148]. Silver nanoparticle dressings are bactericidal because of the synergistic interaction between $\mathrm{Ag}$ ions and the bacterial cell wall, plasma membrane, DNA and proteins, and the enzymes of the electron transport system (Table 3) [145, 149-151].

Silver nanoparticle-incorporated cotton fabric and dressings increased bacterial clearance from infected wounds and significantly decreased the time of wound healing by approximately $72 \mathrm{~h}$ without observed side effects [152-157]. Conjugates of AgNPs-biopolymer (ABP) are synergistic, noncytotoxic, and Generally Recognized As Safe (GRAS) biomaterials in acute and chronic wounds (Fig. 2) [145]. Experimental models documented the synergism of AgNPs with natural rubber latex (NRL), keratin, collagen, silk, gelatin, chitosan, starch, cellulose, and hyaluronic acid [145].

The poly(methyl methacrylate-co-dopamine methacrylamide (MADO)-AgNPs wound dressings inhibited the growth of E. coli, S. aureus, and Pseudomonas aeruginosa ( $P$. aeruginosa). Using the MADO-AgNPs wound dressing resulted in complete skin wound healing in rats and increased epithelialisation within 2 weeks $[158,159]$. Coupling of reduced graphene oxide with $\mathrm{Ag}$-silver chloride $(\mathrm{AgCl})$ nanoparticles generated more oxygen free radicals and improved wound healing with a broad-spectrum antibacterial activity. Reduced graphene oxide/ $\mathrm{Ag}-\mathrm{AgCl}$ nanomaterials accelerated the wound closure and ameliorated reepithelisation in mice after burn injury owing to the antiinflammatory and antioxidant properties of AgNPs $[160,161]$.

\section{(b) Gold nanoparticles (AuNPs)}

Gold nanoparticles (AuNPs) are used in tissue repair, wound healing, and smart drug delivery because of their simple synthesis and chemical stability, SPR, and their ability to absorb near infrared (NIR) light [22, 162-165]. Gold nanoparticles are antioxidants that help wounds heal by preventing the release of ROS (Table 3) [166]. Gold nanoparticles crossed the skin subcutaneous layer and spread over the epidermis layer, facilitating the transcutaneous codelivery of other drugs in-vivo [167]. The treatment of open wounds with AUNPs enhanced the deposition of collagen and granulation tissue formation, reepithelialisation, accelerating wound closure in Wistar Albino rat [168]. Gold nanoparticles ceased the activity of $P$. aeruginosa and $S$. aureus and suppressed both their energy metabolism and the function of adenosine triphosphate (ATP) synthase-an enzyme that creates ATP, the principal molecule for storing and transferring energy in cells [22, 59].

Crosslinking with collagen, gelatin, and chitosan offers AuNPs biocompatibility and biodegradability and increases free radical scavenging capacity [169, 170]. Chitosan-AuNPs composite improved haemostasis as well as epithelial tissue formation in injured rats, compared with chitosan only. The topical application of AuNPs-cryopreserved human fibroblasts reduced inflammation and increased both collagen deposition as well as the rate of overall healing of burn wounds (Table 3) [171, 172].

\section{(c) Zinc oxide nanoparticles (ZnONPs)}

Zinc oxide nanoparticles (ZnONPs) are popular inorganic nanomaterials in burns and delayed wound heal-

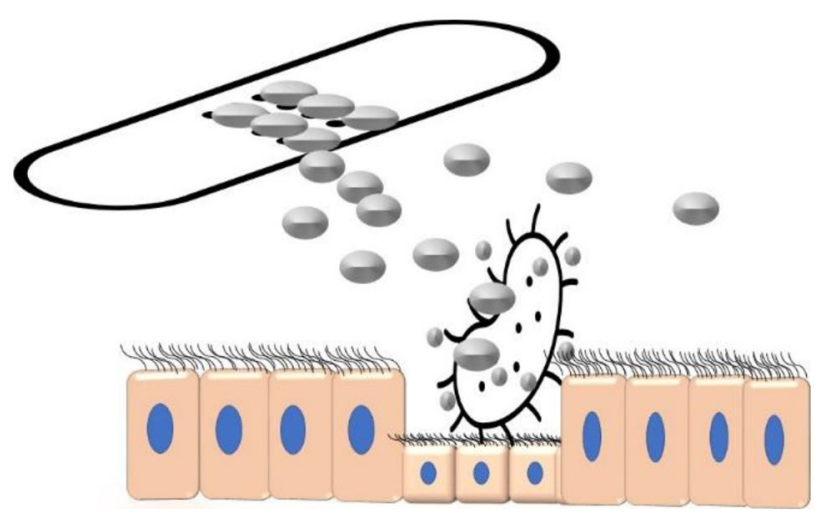

Fig. 2 The antibacterial activity of AgNPs and the promotion of wound healing through reepithelisation 
ing, because they facilitate collagen synthesis and due to their bacteriostatic and bactericidal effects via disrupting the cell membrane and ROS [59, 139, 173-176]. Zinc is one of the most important trace elements that regulate burns and slow-healing wounds via the regulation of DNA and RNA polymerases, ribonuclease, and thymidine kinase [173]. Zinc is a stable element of $>2000$ transcription factors and $>300$ metalloenzymes that are essential for the metabolism of nucleic acids, proteins, and lipids as well as gene transcription in living cells [174]. Zinc oxide nanoparticles with constant valency of zinc ions had high aggregate stability and lower toxicity with the same high permeability via the skin and lipid membranes, compared with AuNPs and AgNPs [175, 177]. The chitosan-ZnONPs hydrogel wound dressing displays proper antibacterial activity with minimal toxicity [178]. The wound dressings of ZnONPs-collagen with $1 \%$ orange essential oil had excellent biocompatibility, inhibited the growth of bacteria, and improved wound closure in-vitro and invivo [179, 180]. Unfortunately, the intrinsic toxicity of ZnONPs hampers their use in wound healing, which requires further assessments (Table 3 ).

\section{(d) Copper nanoparticles (CuNPs)}

Copper-based nanomaterials are potential candidates to accelerate wound healing after thorough toxicity assessment. Copper nanoparticles (CuNPs) accelerated wound closure by stimulating the proliferation of keratinocytes and fibroblasts, epithelialisation, collagen synthesis, extracellular matrix remodelling, and angiogenesis in rats [181, 182]. Copper oxide-based dressings improved wound healing by producing important signal proteins (e.g., transforming growth factor-beta [TGF- $\beta$ ], hypoxia-inducible factor-1 alpha [HIF-1 $\alpha$ ], matrix metalloproteinase-2 [MMP-2], and VEGF), that are involved in wound healing in diabetic mice [182]. Copper nanoparticles-based nanocomposites organise the healing process by regulating cytokines, cells, and growth factors that aid in wound healing [183]. Chitosan-based copper nanocomposites exhibited antifungal and antibacterial properties, increased interleukin-10 (IL-10), VEGF, and TGF- $\beta 1$, and decreased tumour necrosis factor- $\alpha$ (TNF- $\alpha)$, enhancing wound healing in mice (Table 3) [183].

\section{(e) Silica nanoparticles (SiNPs)}

Silica-based wound dressings and scaffold preparations have gained significant attention in wound healing. Silica nanoparticles (SiNPs) helped the skin fibroblast cells proliferate and spread over the wounded area, releasing silicic acid and improving topical wound repair in-vitro [184]. The size, condensation degree, and surface charge of soluble silicic acid control the behaviour of colloidal species - that coexist with silicic acid in SiNPs solution-and cellular effects [184]. Silica nanoparticle-collagen hydrogel nanocomposites in wound dressings reduced fibroblast toxicity, increased the coordinated effect of both SiNPs and collagen, and improved the mechanical strengths and stability against the degradation of the hydrogel (Table 3) [185].

Collagen scaffold dressing containing an antibacterial (i.e., mupirocin) and silica microspheres had synergistic efficacy in wound healing in Wistar Albino rats [186]. Silica microspheres maintained drug release (e.g., antibiotics) and enhanced the proliferation of fibroblast, whereas collagen adsorbed the exudates and rehydrated the necrotic tissues [185]. Likewise, silicon dioxide nanoparticles and polyvinylpyrrolidone (PVP) as a vehicle accelerated the migration and reepithelialisation, supporting the wound healing role of silicabased nanomaterials (Table 3) [187].

\section{(f) Titanium dioxide nanoparticles $\left(\mathrm{TiO}_{2} \mathrm{NPs}\right)$}

Titanium dioxide nanoparticles $\left(\mathrm{TiO}_{2} \mathrm{NPs}\right)$ are suitable wound healing materials due to their antibacterial and antiinflammatory actions, high swelling and WVTR, hydrophilicity, and biocompatibility. Titanium dioxide nanoparticles accelerated wound healing via the production and secretion of monocyte chemoattractant protein-1 (MCP-1), PDGF, macrophage inflammatory protein- $\alpha$ (MIP-1- $\alpha)$, MIP-1- $\beta$, IL-8, and VEGF, in conjunction to contact system (FXII) activation [188]. Bacterial cellulose- $\mathrm{TiO}_{2}$ nanoconjugates are promising wound dressings due to their biocompatibility and antibacterial activities. The staining of mice burn wound tissues illustrated that bacterial cellulose- $\mathrm{TiO}_{2}$ facilitated reepithelialisation, the migration of fibroblast, and angiogenesis, enhancing wound closure $[189,190]$. The wound dressings of $\mathrm{TiO}_{2} \mathrm{NPs}$ enclosed with pectin and chitosan pose antibacterial and interesting wound healing properties [191]. Nano$\mathrm{TiO}_{2}$-chitosan with collagen artificial skin nanocomposite sustained a moderate level of TNF- $\alpha$, denoting its antiinflammatory action (Table 3) [190].

\section{(g) Super paramagnetic iron oxide nanoparticles (SPI- ONs)}

Super paramagnetic iron oxide nanoparticles (SPIONs) have appealing applications in wound healing and drug delivery vehicles, because they own unique antibacterial and physicochemical properties (i.e., nano size, ease-ofamalgamation, minor toxicity, and biodegradability) [192]. 
Super paramagnetic iron oxide nanoparticles are small types of magnetic nanoparticles that consist of iron oxide cores or mixtures of iron oxides with cobalt, copper, manganese, or nickel [193]. Gold-coated SPIONs strongly penetrate bacterial biofilms and show higher toxicity. The intensified bactericidal effect of SPIONs is attributed to the cores of SPIONs and the intermediary gold shell that induce heat upon the application of laser and magnetic fields [194]. Iron oxide nanoparticle-decorated carbon nanotubes successfully healed wounds with a broad-spectrum antibacterial activity in animals [195]. Super paramagnetic iron oxide nanoparticles are coated with specific biocompatible polymers (e.g., polyethylene glycol [PEG] or dextran) that facilitate the conjugation of therapeutic compounds and improve their blood distribution. Super paramagnetic iron oxide nanoparticle-thrombin conjugates ameliorated skin tensile strength and enhanced the wound healing ability of thrombin by increasing its half-life in human plasma versus the free thrombin in rat incisional wounds (Table 3) [196, 197].

\section{Ceramic nanoparticles}

Ceramic nanoparticles are widely considered in imaging applications, catalysis and photocatalysis, drug delivery, and the photodegradation of dyes [198, 199]. Ceramic nanoparticles are inorganic nonmetallic solids (e.g., silica/ alumina titania, zirconia, silicon nitride/carbide) that are synthesised via successive cooling and heating, and are available in dense, polycrystalline, amorphous, hollow or porous forms [200-203]. The encapsulation of dense bioactive glass into gelatin-chitosan polymer activated alkaline phosphatase with the highest rate (i.e., $80 \%$ ) of bone formation [204]. The multifunctional poly-citrate-siloxane elastomer-based bioactive glass was effective in bone tissue regeneration [205]. Bioactive glass slowly releases silicon and calcium ions at wound sites, promoting angiogenesis by stimulating cell proliferation and the release of cytokines, such as HIF-1 and VEGF [206, 207]. The silicon ions generated by bioactive glass protect endothelial cells from hypoxia and stimulate the expression of connexin 43 between endothelial cells and fibroblasts, encouraging angiogenesis (Table 3) [208].

\section{Organic and hybrid nanoparticles in wound healing}

\section{(a) Lipid-based nanoparticles}

Lipid-based nanoparticles such as liposomes are the foundation of lipid nanotechnology as a drug delivery vehicle due to ease-of-delivery, size modulation, and charge and surface properties [210, 211]. Loss of growth factor coreceptors leads to growth factor (i.e., glypican-1) resistance that may prevent the induction of angiogenesis in wound healing in diabetic mouse. The delivery of growth factor cell surface receptors in a proteoliposome overcame this resistance and improved both wound healing and ischaemic revascularisation [212]. Other lipid-based nanoparticles hold promise for treating critical limb ischaemia and peripheral vascular diseases (PVDs) (Table 4) [213].

Solid lipid nanoparticles (mean size of $\sim 180 \mathrm{~nm}$ ) stabilise drugs and sustain their release when compared to liposomes, and they are safer than polymeric carriers, because they do not employ organic solvents during their production $[214,215]$. They are a modern pharmaceutical delivery system with reshaped characteristics of liposomes, microemulsions, suspensions, and polymeric nanoparticles. Solid lipid nanoparticles are highly stable, biodegradable, nontoxic, and achieve chemically stable drug delivery systems with fewer limitations, overcoming the common issues faced with other nanoparticles. With higher efficiency and minimal toxicity, solid lipid nanoparticles deliver the following to the target site: proteins and peptides, temperaturesensitive drugs and those with physicochemical incompatibilities and lower pharmacokinetic profiles. They also deliver bioactive compounds, including morphine, resveratrol, and silver sulfadiazine in wound healing. Topical morphine-loaded solid lipid nanoparticles sustained the release of morphine, enhanced reepithelialisation, allowed keratinocytes to spread over the dermis, and accelerated the wound closure of a human-based three-dimensional wound healing model with lower toxicity and irritation [216]. Nonetheless, the production of solid lipid nanoparticles may degrade or eject the used drugs because of the evolved heat and stress. The tendency of solid lipid nanoparticles towards gel formation, particle size, and various shapes should be considered as well (Table 4) [217].

\section{(b) Polymer nanoparticles}

Biomedicine and bioengineering have underlined the importance of biocompatible polymeric nanoparticles [218]. Poly lactic-co-glycolic acid (PLGA), chitosan, gelatine, alginate, and other polymer combinations are commonly used to prepare the majority of polymeric nanoparticles [219, 220]. Conjugation with polymeric nanoparticles stabilises drugs against proteases, facilitates controlled drug release, and therefore reduces dosing frequency. Polymeric nanoparticles are effective biomolecules for the delivery of genes, growth factors, and antibiotics [221, 222]. The availability of growth factors (e.g., fibroblast growth factor-2 [FGF2] and EGF) ensures proper wound healing; however, 
Table 4 The properties/actions and applications of organic and hybrid nanoparticles in wound healing

\begin{tabular}{|c|c|c|c|}
\hline Nanoparticles & Distinctive Properties/Actions & Application(s) & References \\
\hline Lipid-based nanoparticles & $\begin{array}{l}\text { - Size modulation } \\
\text { - Ease-of-delivery } \\
\text { - Charge and surface properties } \\
\text { - Overcome growth factor resistance } \\
\text { - } \uparrow \text { revascularisation and wound healing }\end{array}$ & $\begin{array}{l}\text { - Drug delivery vehicle } \\
\text { - Wound healing }\end{array}$ & {$[210-212]$} \\
\hline Solid Lipid nanoparticles & $\begin{array}{l}\text { - High stability, biodegradability, and } \\
\text { efficiency } \\
\text { - Nontoxic } \\
\text { - Achieve chemically stable drug delivery } \\
\text { systems with fewer limitations } \\
\text { - Overcome the common issues faced with } \\
\text { other nanoparticles } \\
\text { - Deliver the following to the } \\
\text { target site: proteins and peptides, } \\
\text { temperature-sensitive drugs, drugs } \\
\text { with physicochemical incompatibility, } \\
\text { and others with lower pharmacokinetic } \\
\text { profile } \\
\text { - Deliver bioactive compounds, including } \\
\text { morphine, resveratrol, and silver } \\
\text { sulfadiazine in wound healing } \\
\text { Disadvantages: } \\
\text { - May degrade or eject the used drugs } \\
\text { because of the evolved heat and stress } \\
\text { - Gel formation } \\
\text { - Particle size and various shapes should } \\
\text { be considered }\end{array}$ & $\begin{array}{l}\text { - Wound healing } \\
\text { - Pharmaceutical delivery } \\
\text { system }\end{array}$ & {$[216,217,259-261]$} \\
\hline Polymer nanoparticles & $\begin{array}{l}- \text { Antibacterial } \\
- \text { Help drugs avoid degradation by the } \\
\text { proteases } \\
-\uparrow \text { granulation tissue formation } \\
-\uparrow \text { collagen deposition } \\
-\uparrow \text { reepithelialisation and } \\
\text { neovascularisation } \\
-\uparrow \text { IL- } 6 \text { and VEGF } \\
- \text { Control inflammation } \\
-\uparrow \text { controlled drug release and skin } \\
\text { permeation } \\
-\downarrow \text { dosing frequency } \\
-\uparrow \text { delivery and stability of genes, } \\
\text { EGF and FGF-2, and antibiotics upon } \\
\text { encapsulation }\end{array}$ & $\begin{array}{l}\text { - Wound and ulcer healing } \\
\text { - Burn-induced infections } \\
\text { - Therapeutic angiogenesis } \\
\text { - Gene therapy } \\
\text { - Tissue engineering } \\
\text { - Drug delivery }\end{array}$ & [218-227] \\
\hline $\begin{array}{l}\text { Antibiotic-loaded nanoparticles } \\
\text { (nanobiotics) }\end{array}$ & $\begin{array}{l}- \text { Broad spectrum antibacterial activity } \\
-\uparrow \text { actions of antibiotics against MDR } \\
\text { microorganisms } \\
-\uparrow \text { tissue regeneration } \\
-\downarrow \text { toxicity }\end{array}$ & - Wound healing & [231-234] \\
\hline Nitric oxide-releasing nanoparticles & $\begin{array}{l}-\uparrow \text { skin homeostasis and collagen } \\
\text { deposition } \\
-\uparrow \text { wound closure and strength } \\
-\uparrow \text { keratinocyte proliferation and } \\
\text { angiogenesis } \\
- \text { Broad spectrum antibacterial } \\
-\uparrow \text { reactive nitrogen intermediates } \\
-\downarrow \text { suppurative inflammation } \\
-\downarrow \text { degradation of collagen }\end{array}$ & - Wound healing and repair & [236-242] \\
\hline
\end{tabular}


Table 4 (continued)

\begin{tabular}{|c|c|c|c|}
\hline Nanoparticles & Distinctive Properties/Actions & Application(s) & References \\
\hline \multirow[t]{2}{*}{ Green synthesised nanoparticles } & $\begin{array}{l}\text { AgNPs } \\
-\uparrow \text { activity against MDR bacteria } \\
-\uparrow \text { wound healing and contraction rate } \\
-\uparrow \text { dermis reepithelialisation } \\
-\downarrow \text { scars, TNF- } \alpha, \text { IL- } 1 \beta \text {, and IL-6 }\end{array}$ & - Wound healing & {$[252-258]$} \\
\hline & $\begin{array}{l}\mathrm{TiO} \mathrm{O}_{2} \mathrm{NPs}, \mathrm{AuNPs} \text {, and } \mathrm{CuONPs} \\
-\uparrow \text { activity against MDR bacteria } \\
-\uparrow \text { wound healing } \\
-\uparrow \text { connective tissue } \\
-\uparrow \text { dermis reepithelialisation } \\
-\uparrow \text { proliferation and migration of } \\
\quad \text { epidermal cells } \\
-\uparrow \text { wound contraction rate } \\
-\uparrow \text { fibroblasts, macrophages, and collagen } \\
\quad \text { fibers } \\
-\downarrow \text { prevent infections and treatment- } \\
\text { related side effects }\end{array}$ & & \\
\hline
\end{tabular}

the wound microenvironment has various proteolytic enzymes (e.g., matrix metalloproteinases [MMPs]) that significantly reduce their half-life [223]. Fortunately, the encapsulation of these growth factors within polymer nanoparticles increases their stability and sustains their bioactivity and release (Table 4).

Reports have focused on the encapsulation of antimicrobials into polymeric nanoparticles [224, 225]. For instance, LL37-loaded PLGA nanoparticles accelerated wound healing, exhibited antibacterial activity against E. coli, and induced cell migration without affecting the proliferation and metabolism of keratinocytes in $\mathrm{HaCaT}$ cells. The treatment of full thickness excisional wound mouse model with PLGA-LL37 nanoparticles displayed higher deposition of collagen and granulation tissue formation, reepithelialisation, and neovascularisation. It also increased IL-6 and VEGF with the improvement of angiogenesis and control of the inflammatory response [224]. Topical norfloxacinloaded PLGA nanoparticles were safe and sustained drug release to $24 \mathrm{~h}$ with better skin penetration and low number of in-vitro applications. Norfloxacin-loaded nanoparticles also had better performance against $S$. aureus and $P$. aeruginosa., bringing hope to the treatment of burn-induced infections [225]. The gelatin microencapsulation of FGF-2 preserved its biological activity, promoting its application in therapeutic angiogenesis, gene therapy, tissue engineering, and drug delivery (Table 4) [226].

Poly-L-lactic (PLLA) acid-based wound dressings loaded with EGF enhanced the healing of gastric ulcers [227]. The Food and Drug Administration (FDA) has only approved the platelet-derived growth factor (PDGF-BB) for diabetic foot ulcers. Hyalu- ronic acid-based porous nanoparticles supplied with PDGF-BB demonstrated higher efficacy to treat rat ulcers [228]. Poly-L-lactic acid are interesting nanocarriers to deliver extremely hydrophobic and poorly soluble medicines and proteins at the correct rate. Using PLLA nanoparticles reduced the toxic effects of curcumin-bortezomib compared to the unencapsulated form [229]. The use of PLA-PEG nanoparticles also increased the encapsulation efficiency of adapalene (a topical retinoid used for wound healing) (Table 4) [230].

\section{(c) Antibiotic-loaded nanoparticles (nanobiotics)}

Nanobiotics are the modern revolution that improves the functions of conventional antibiotics in wounds against MDR microorganisms. Vancomycin-modified nanoparticles exhibited a broad-spectrum activity in-vitro [231]. Polyacrylate nanoparticle-antibiotics and poly(butyl acrylate-styrene) nanoparticle-Nthiolated $\beta$-lactam conjugates had significant activity with lower toxicity against MRSA that cause severe infections in different parts of the body [232, 233]. The dressing of gelatin/chitosan/epigallocatechin gallate nanoparticles incorporated in a poly $(\gamma$-glutamic acid)/gelatin hydrogel with activated carbon fibers and gentamicin, was easy to remove from the site of injury, inhibited bacterial growth, and improved reepithelialisation in-vitro and in-vivo. The PLGA nanoparticles having gentamicin were synthesised by the double emulsion evaporation method (Fig. 3) [234]. Gentamicin-loaded PLGA nanoparticles warrant the design of drug delivery systems using smart wound dressings with significant antibacterial properties (Table 4) [235]. 


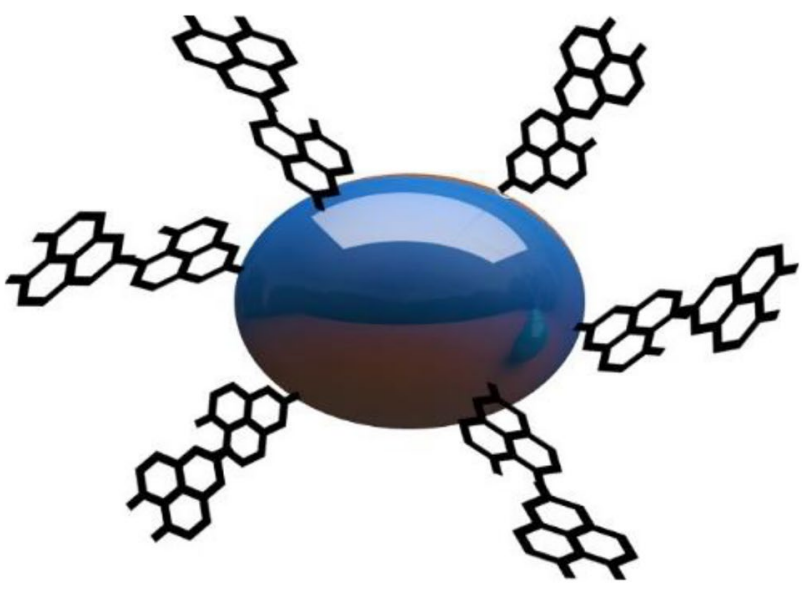

Fig. 3 The conjugation of nanoparticles with antibiotics. Nanoparticles are represented in blue colour, whereas antibiotics are depicted in black

\section{(d) Nitric oxide-releasing nanoparticles}

Nitric oxide controls skin homeostasis and the proliferation of keratinocytes and facilitates angiogenesis as well as the deposition of the extracellular matrix (ECM) proteins in wound healing. Nitric oxide is involved in systemic lupus erythematosus (SLE) and psoriasis that have deregulated inducible nitric oxide synthase levels [236, 237]. Inducible nitric oxide-knockout mice have a delayed reepithelialisation with a reduced number of keratinocytes in excisional wounds [238]. L-argininenitric oxide synthase substrate-enhanced the deposition of collagen, implicating nitric oxide as an essential element in wound closure (Table 4) [238].

There is ample evidence for the broad-spectrum antibacterial role of nitric oxide. The transcription of inducible nitric oxide synthase is upregulated, and the production of high-output nitric oxide ensues upon the stimulation of microbial pattern recognition receptors in phagocytic cells. Nitric oxide disrupts DNA replication and cell respiration by deactivating zinc metalloproteins and interacting with ROS to create reactive nitrogen intermediates [239, 240]. Finally, the antimi- crobial effector molecules act within the microbial cells [237]. Nitric oxide-releasing coatings on biomaterials decrease the rate of biomaterial-related infections. Monofilament polypropylene mesh supported by nitric oxide-releasing carbon-based coatings eradicated $S$. aureus and other pathogen biofilms invitro [241]. Coating medical grade silicone elastomer implants with a nitric oxide-releasing sol-gel-derived film decreased the percentage (82\%) of infected subcutaneous implants inoculated with $S$. aureus in a murine model [242]. Figure 4 illustrates the fusion of the diazeniumdiolate $\left[-\mathrm{N}(\mathrm{O}) \mathrm{N}=\mathrm{O}^{-}\right]$functional group with nitric oxide-releasing polyurethane in aqueous environments [243]. Aminosilane-based sol-gel chemistry fabricates organic-inorganic polymer matrices where the properties are controlled by the nature and quantity of diamine-containing organosilane precursors and sol-gel processing conditions [242, 244, 245]. Nitric oxide-releasing SiNPs completely inhibited Candida albicans, E. coli, P. aeruginosa, S. epidermidis, and S. aureus in-vitro [246-248]. However, another study showed that bacteria display nitric oxide-mediated antibiotic resistance by the chemical refinement of harmful compounds and accumulating ROS [249]. Treatment with nitric oxide nanoparticles altered the local cytokine milieu, reduced the suppurative pattern of inflammation, and decreased both the pathological burden and the degeneration of collagen in mouse models infected with A. baumannii (Table 4) [250].

\section{(e) Green synthesised nanoparticles}

Green-synthesised $\mathrm{TiO}_{2} \mathrm{NPs}$, AgNPs, AuNPs, and $\mathrm{CuONPs}$ enhance wound healing and decrease or prevent infections and treatment-related side effects [168, 251, 252]. Green synthesised nanoparticles such as AgNPs coupled with phytoextracts are ecofriendly and cost-effective, possess antibacterial and antifungal properties, and promote wound healing [251, 252]. For example, the preparation of greensynthesised AgNPs using the extracts of Catharanthus
Fig. 4 The release of nitric oxide (red spheres) upon the attachment of the diazeniumdiolate group to nitric oxidereleasing polymer (yellow spheres) by covalent or noncovalent bonding

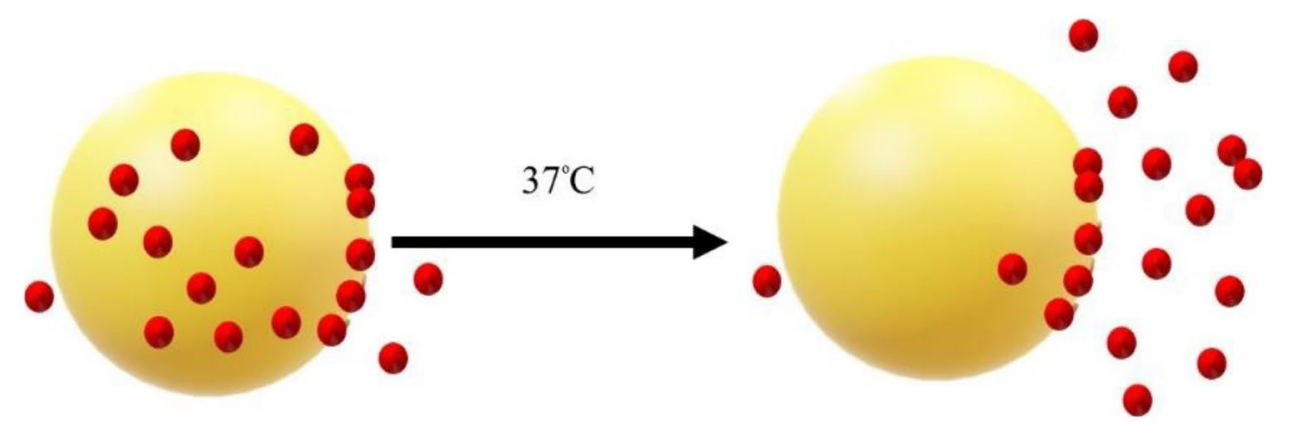


roseus and Azadirachta indica was effective against MDR bacteria and ameliorated excision wound healing in mice [253]. The biosynthesis of stable AgNPs using the fungus of Orchidantha chinensis successfully treated the Sprague Dawley rats with multistrain-infected wounds [254]. The produced AgNPs minimised the scars, reepithelialised the epidermis, accelerated wound healing as well as the wound contraction rate, and downregulated the level of IL-6, IL-1 $\beta$, and TNF- $\alpha$ (Table 4) [254]. Genipin (a compound prepared from geniposide, which is extracted from Penicillium nigricans, a slow-growing fungus) when crosslinked with chitosan, PEG, and AgNPs enhanced wound healing with higher antibacterial activity (Table 4) [255]. In Wistar Albino male rats, AgNPs with Coleus forskohlii root extract was effective in healing full thickness excision wounds [168]. A mixture of AgNPs in octadecylamine-modified montmorillonite clay (ODA-MMT), Homalomena aromatica leaves extracts, and hyperbranched epoxy, also was an effective wound healing scaffold with inborn antimicrobial characteristics (Fig. 5) [256].

The gold nanoparticles synthesised by the extract of Coleus forskohlii root significantly accelerated the reepithelialisation of excision wounds and increased the rate of proliferation, formation of connective tissue, and the migration of epidermal cells in Wistar Albino rats [168]. In the presence of Moringa oleifera leaf extract, the synthesis of $\mathrm{TiO}_{2} \mathrm{NPs}$ reduced the excision wound area and enhanced wound contraction in Wistar Albino rats [257]. The biosynthesis of CuONPs using the extract of Ficus religiosa leaf facilitated wound healing, inhibited the human pathogenic bacteria, and increased the growth of fibroblasts, collagen fibers, and macrophages in Wistar Albino rats (Table 4) [258].

\section{Nanofibers in wound healing}

Nanofibers stand out in wound healing and drug delivery because of their small size, physical and mechanical qualities, high loading capacity, and controlled drug release
[262]. Electrospun nanofibers modulate cell proliferation, migration, differentiation, and the deposition of ECM, allowing their manufacturing into engineered skin tissues, dermal substitutes, wound dressings, and sutures for wound healing [263]. The careful choice of nanofiber components helps electrospun nanofibers mimic the biomechanical properties of the human skin [264, 265]. Electrospun nanofibers are highly porous with a large surface area-to-volume ratio to develop novel scaffolds of natural polymers that carry bioactive substances [263, 266]. Electrospinning builds up polymer nanofibers in a connected three-dimensional network to fabricate nanomaterials (Fig. 6) [267]. Natural polymers (e.g., silk fibroin, chitosan, collagen, gelatin, and synthetic biodegradable polymers) facilitate cell proliferation and attachment, whereas synthetic polymers offer scaffold mechanical stability [218]. These characteristics make them available for use in biosensors, intelligent textiles and clothing, tissue engineering scaffolds, and drug delivery systems [268]. Creative electrospinning develops specialised mats with porous, aligned, hollow, and core-shell nanofibers, which act as skin repair substitutes and enhance the removal of wound exudate, promote oxygen diffusion, and control water loss [269]. The electrospun nanofibrous matrix of type I collagen allowed half of the proliferating normal human epidermal keratinocytes to spread and to adhere, accelerating wound healing in early-stage wounds [270]. The in-vitro proliferation of primary human dermal fibroblast as well as the healing of ex-vivo full-thickness human skin wound model have improved with silk fibroin electrospun fibers with diameters of 250-300 $\mathrm{nm}$ compared with 1- $\mu \mathrm{m}$ fibers (Table 5) [271].

The spatially arranged collagen containing nanofibrous matrices helped the human dermal fibroblasts elongate with focal adhesion clustering and display faster cell migration and a higher rate of differentiation to myoblasts in-vitro [272]. Such architecture stimulated the integrin $\beta 1$ signaling which is the key pathway for these cellular responses. Human dermal fibroblasts on fibrinogen containing nanofiber matrices had faster migration and higher expression of the differentiated phenotype $\alpha$-smooth muscle actin with the aid of exogenous TGF- $\beta 1$. The electrospun PLA

Fig. 5 The green synthesis of silver nanoparticles (AgNPs)

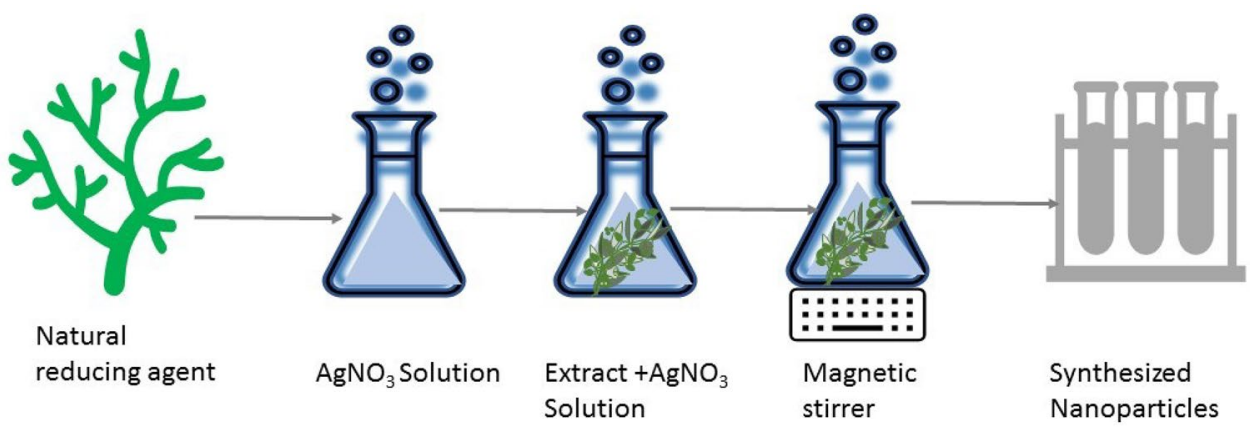




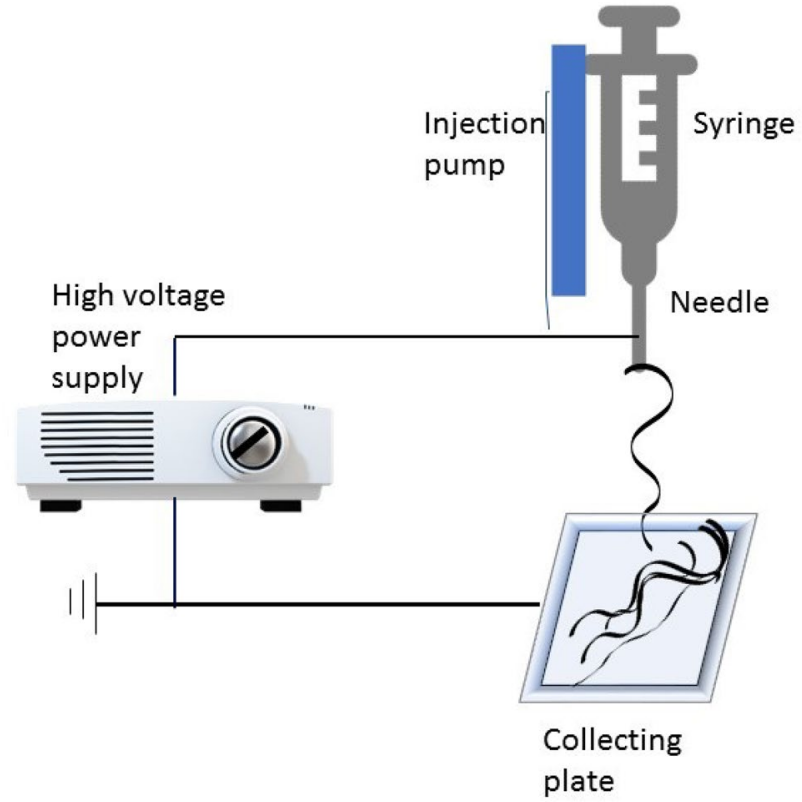

Fig. 6 The production of nanofibers via electrospinning

nanofibers coated with fibrin significantly increased the type I collagen expression and synthesis, spreading, population density, and mitochondrial activity of human dermal fibroblasts (Table 5) [273].

\section{(a) Synthetic polymer-based electrospun nanofibers}

Polycaprolactone is a biocompatible and a biodegradable polyester polymer that reduces inflammatory infiltrate and increases wound healing and tissue regeneration [274, 275]. Polycaprolactone is a good matrix for carrying natural substances due to its encouraging mechanical properties, hydrophobicity, excellent spinning, and delayed degradation. Polyvinyl alcohol is a semicrystalline biocompatible polymer that is used in the biomaterials of orthopaedic and dermal tissue engineering. It is a copolymer that enhances the mechanical properties and the electrospinnability of chitosan, where higher ratio of chitosan in PVA-chitosan blends leads to higher bacterial activity (Table 5) [276-279].

Polycaprolactone-based electrospun nanofibrous membrane is an effective wound dressing that facilitates the adhesion and the proliferation of human dermal fibroblast in-vitro; it may be a possible alternative to treat burninduced wounds and skin defects [280]. The electrospun PCL-collagen nanofibers maintain the active delivery of TGF- $\beta 1$ to promote the differentiation of myofibroblasts [281]. The three-dimensional cultures of human hairfollicle-derived melanocytes and normal human epidermal melanocytes have reinforced the melanotic features upon seeding on the mesh of electrospun PCL fibers via the expression of terminal melanotic differentiation genes [282]. The mesh of electrospun PCL nanofibrous scaffold also helped cultivated rat hair-follicle stem cells rapidly proliferate, migrate, and differentiate [283]. The electrospun poly(L-lactide-co- $\varepsilon$-caprolactone) (PLCL) and polyurethane random nanofiber scaffolds mitigated the hypertrophic scar (HSc) contraction in-vitro and invivo [284, 285]. The electrospun PLCL and polyurethane nanofiber scaffolds seeded with human dermal fibroblasts showed less contraction with fewer $\alpha$-SMA positive myofibroblasts. The scaffolds of collagen-coated polyurethane or PLCL nanofibers cultivated underneath skin grafts significantly reduced the HSc contraction and scar stiffness compared with the standard-of-care Integra (silicone membrane removed) in a murine model (Table 5).

\section{(b) Natural polymer-based electrospun nanofibers}

\section{Polymers of protein origin}

Electrospun nanofibers developed from healthy skin collagen allow the ECM to give extra support to keratinocytes and fibroblasts to strongly attach to the fibres, migrate through the wound bed, and regenerate and repair the injured tissue (Fig. 7) [286]. Collagen is the most predominant protein in the body and is the principal fibrous protein in the ECM that supports tissues' and organs' structures and regulates cell functions [287]. Collagen is malleable, bioresorbable, nontoxic, antimitogenic, highly biocompatible, could be combined with other copolymers, and is a suitable biomaterial for nanofibrous mats [288]. However, collagen has some drawbacks, including the difficult work involved, high purification cost, and the risk of disease transmission [289]. Silk fibroin, an ideal candidate for biomedical applications, has unique biocompatibility and biodegradability, causes low inflammatory reactions, and provides adequate oxygen and WVTR [290]. Various insects (e.g., silkworm) produce the typical fibrous protein - silk. Fibroin (silk filaments protein) can be regenerated in powders, membranes, fibers, or gels [291]. The adaptability and the simple production of fibroin make it easier to obtain materials with appropriate properties (Table 5) [286].

\section{Algae polysaccharides}

Alginate polysaccharide-based biomaterials are costeffective, versatile, abundant, and play an essential role in wound healing [292, 293]. Sodium alginate is tissuecompatible, nontoxic, hydrophilic, biodegradable, and 
Table 5 The properties/actions and applications of nanofibers in wound healing

\begin{tabular}{|c|c|c|c|}
\hline Nanofibers & Distinctive Properties/Actions & Application(s) & Reference(s) \\
\hline \multicolumn{4}{|c|}{ Synthetic Polymer-Based Electrospun Nanofibers } \\
\hline & $\begin{array}{l}\text { - } \uparrow \text { mechanical properties and electrospinnability } \\
\text { of biopolymers (e.g., chitosan) } \\
-\uparrow \text { wound closure } \\
-\downarrow \text { inflammatory infiltrate } \\
\text { - Hydrophobic } \\
\text { - Excellent spinning } \\
\text { - Delayed degradation }\end{array}$ & $\begin{array}{l}\text { - Wound healing } \\
\text { - Tissue regeneration (e.g., } \\
\text { dermatology) } \\
\text { - Orthopaedics }\end{array}$ & [274-279] \\
\hline \multicolumn{4}{|c|}{ Natural Polymer-Based Electrospun Nanofibers } \\
\hline \multirow[t]{2}{*}{ Polymers of protein origin } & $\begin{array}{l}\text { Collagen } \\
\text { - Nontoxic } \\
\text { - Not mitogenic } \\
\text { - Better cellular response } \\
\text { - Malleable } \\
\text { - Bioresorbable } \\
\text { - Highly compatible } \\
\text { - Could be combined with other copolymers } \\
\text { Disadvantages } \\
\text { - } \uparrow \text { purification cost } \\
\text { - Difficult work involved } \\
\text { - Risk of disease transmission }\end{array}$ & - Suitable for nanofibrous mats & {$[286,288]$} \\
\hline & $\begin{array}{l}\text { Silk Fibroin } \\
\text { - Biocompatible and biodegradable } \\
\text { - Low inflammatory reactions } \\
\text { - Adequate oxygen WVTR }\end{array}$ & - Biomedical applications & {$[290,291]$} \\
\hline Algae polysaccharides & $\begin{array}{l}\text { - Biodegradable and affordable } \\
\text { - Versatile and abundant } \\
\text { - Tissue-compatible } \\
\text { - Immunomodulatory } \\
\text { - Antioxidant } \\
\text { - Anticoagulant and antitumour } \\
\text { - } \uparrow \text { wound closure } \\
\text { Disadvantages } \\
\text { - Limited electrospinnability }\end{array}$ & $\begin{array}{l}\text { - Wound dressings } \\
\text { - Skin regeneration }\end{array}$ & [292-296] \\
\hline \multirow[t]{3}{*}{ Plant polysaccharides } & $\begin{array}{l}\text { Starch } \\
\text { - Abundant } \\
\text { - Physically or chemically amended to be utilised } \\
\text { in wound dressings } \\
\text { - Electrospun starch-hyaluronic acid/ } \\
\text { (polyurethane-based electrospun nanofibers } \\
\text { patch: } \\
\checkmark \text { biocompatible } \\
\checkmark \text { biodegradable } \\
\checkmark \text { confers surface hydrophilicity } \\
\checkmark \text { improves the mechanical durability }\end{array}$ & $\begin{array}{l}\text { - Wound healing } \\
\text { - Drug delivery }\end{array}$ & {$[299,301]$} \\
\hline & $\begin{array}{l}\alpha \text {-cellulose nanofibers } \\
\text { - Antibiotic-loaded } \alpha \text {-cellulose nanofibers diminish } \\
\text { the wound size }\end{array}$ & - Wound healing & [304] \\
\hline & $\begin{array}{l}\text { Pectins } \\
\text { - Rapid exudate absorption } \\
\text { - Moderate hydrophilicity } \\
\text { - Antibacterial }\end{array}$ & - Wound healing & {$[307,308]$} \\
\hline
\end{tabular}


Table 5 (continued)

\begin{tabular}{|c|c|c|c|}
\hline Nanofibers & Distinctive Properties/Actions & Application(s) & Reference(s) \\
\hline \multirow[t]{2}{*}{ Animal polysaccharides } & $\begin{array}{l}\text { Chitosan } \\
\text { - Antioxidant and antiinflammatory } \\
\text { - Antibacterial } \\
\text { - Biocompatible } \\
\text { - Electrospun nanofiber mats with chitosan- } \\
\text { graft-PCL: } \\
\checkmark \text { excellent cell attachment and proliferation } \\
\text { Disadvantages } \\
\text { - Chitosan pristine fibers have limited biomedical } \\
\text { applications because of its poor mechanical } \\
\text { properties }\end{array}$ & $\begin{array}{l}\text { - Wound healing } \\
\text { - Drug development } \\
\text { - Tissue engineering }\end{array}$ & {$[268,279,316-319]$} \\
\hline & $\begin{array}{l}\text { Hyaluronic acid } \\
\text { - Nonimmunogenic } \\
\text { - Biodegradable } \\
\text { - Biocompatible } \\
\text { - High wettability } \\
\text { - High ability to be chemically modified }\end{array}$ & $\begin{array}{l}\text { - Wound healing } \\
\text { - Drug delivery } \\
\text { - Tissue engineering } \\
\text { - Viscosupplementation }\end{array}$ & {$[161]$} \\
\hline \multirow[t]{2}{*}{ Fungal polysaccharides } & $\begin{array}{l}\text { Pullulan } \\
\text { - Nontoxic } \\
\text { - Nonmutagenic } \\
\text { - Tasteless } \\
\text { - Odourless } \\
\text { Disadvantages } \\
\text { - The high hydrophilicity of pullulan hinders its } \\
\text { tissue engineering applications, limiting cellular } \\
\text { attachment and proliferation and preventing } \\
\text { protein adsorption }\end{array}$ & $\begin{array}{l}\text { - Pharmacy } \\
\text { - Biomedicine }\end{array}$ & [326-330] \\
\hline & $\begin{array}{l}\text { Sonifilan (SPG) } \\
\text { - Embrace molecular components, functional } \\
\text { polymers, and nanoparticles to form water- } \\
\text { soluble one-dimensional nanocomposites }\end{array}$ & - Drug delivery & [333] \\
\hline \multirow[t]{2}{*}{ Bacterial polysaccharides } & $\begin{array}{l}\text { Dextran Gum } \\
\text { - Dextran crosslinking tailors its biodegradation } \\
\text { stability and retains its mechanical features in } \\
\text { moist conditions } \\
\text { - Electrospun dextran-boric acid: } \\
\text { - prepare a steady network of dextran-boric } \\
\text { acid electrospun nanofibers with controlled } \\
\text { degradation time }\end{array}$ & - Wound healing & {$[338-341]$} \\
\hline & $\begin{array}{l}\text { Xanthan Gum } \\
\text { - Thermostable } \\
\text { - Generates self-assembled micro or nanoscale } \\
\text { structures }\end{array}$ & $\begin{array}{l}\text { - Regenerative medicine } \\
\text { - Tissue engineering } \\
\text { - Controlled drug delivery }\end{array}$ & {$[342,343]$} \\
\hline
\end{tabular}

affordable, making it suitable in skin regeneration and curing exuding wounds [294]. Marine algae polysaccharides exhibit immunomodulatory, antioxidant, anticoagulant, and antitumour actions. Pseudomonas spp. and Azotobacter vinelandii and algae produce alginates, biodegradable polysaccharides, and negatively charged polymers. Alginates absorb the surplus exudate and provide moist conditions for rapid wound healing [295]. Yet, alginates have limited electrospinnability to be linked with compatible polymers [296]. Blending alginates with synthetic polymers (e.g., polyethylene oxide [PEO] or
PVA) enhances their electrospinnability and mechanical potency (Table 5) [297].

\section{Plant polysaccharides}

Plant polysaccharides are biodegradable polymers with steady structures, diverse biological, physicochemical, and strong hydrophilicity/viscosity characteristics that regulate the rheological properties of the fluid system [298]. Starch is an abundant polysaccharide biopolymer with interesting applications in drug delivery and wound dressings. The main components of 
Fig. 7 The scanning electron microscope (SEM) images of collagen fibers (a) before and (b) after spinning
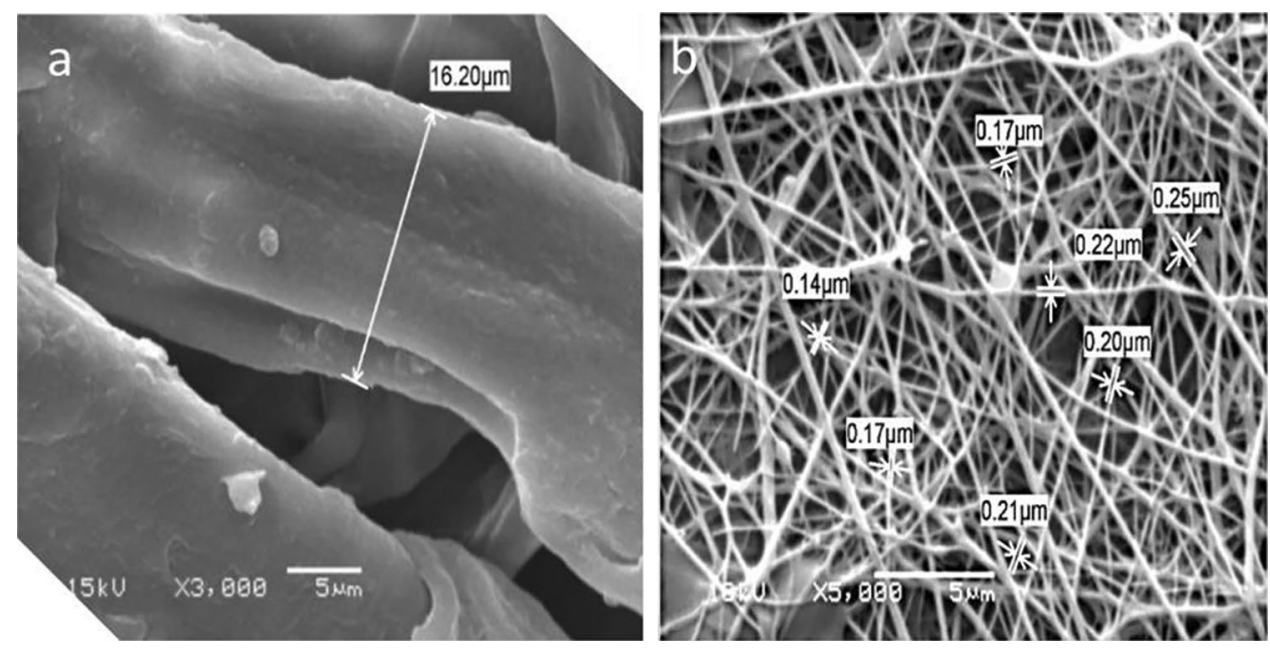

starch (i.e., amylopectin and amylose) can be physically/chemically amended to be utilised in wound dressings [299]. Wet electrospinning is a green method that develops pure starch-based nanofibers with high stability in water at room temperature using sodium palmitate [300]. Research currently focuses on manufacturing crosslinked electrospun nanofibers, such as PVA/starch/ chitosan nanofibrous mats in wound dressings [299]. The modified coaxial electrospinning forms a core-shell starch-hyaluronic acid/polyurethane-based electrospun nanofibers patch that is biocompatible, biodegradable, confers surface hydrophilicity, and improves the mechanical durability (Table 5) [301].

Nanoscale cellulose fibers are attractive due to large surface area compared with their microscale forms [302]. Many cellulose derivatives such as carboxymethyl cellulose (CMC), cellulose acetate, $\alpha$-cellulose, and ethyl cellulose develop different electrospun nanofibers in wound dressings [303-305]. In contrast to drug-free $\alpha$-cellulose nanofibers, antibioticloaded $\alpha$-cellulose nanofibers diminish the wound size with desirable bioactivity (Table 5) [304]. Pectin-based electrospun nanofiber scaffolds might function as better wound dressings with significant antibacterial activity. They absorb more exudate in a shorter time versus alginate- and chitosan-based electrospun nanofiber patches. Pectin polysaccharides are complex molecules with irregular carbohydrate chains [306, 307]. Pectins act as an exudate-absorbing component in hydrocolloidal wound dressings due to their moderate hydrophilicity [307, 308]. Gums - a large group of polysaccharides - are a novel source of electrospun nanofiber biopolymers with different pharmaceutical applications [309]. For example, electrospun nanofiber scaffolds comprising gum Arabic, gum karaya, gum guar, Azivash gum, and gum tragacanth, are used in wound dressings (Table 5) [310-315].

\section{Animal polysaccharides}

Animal polysaccharides - chitosan and hyaluronic acidpossess antioxidant, antibacterial, and antiinflammatory properties, and can be used in wound healing and drug development [316]. Chitosan is a biocompatible biopolymer with interesting antiinflammatory and antimicrobial properties in wound healing [317]. Chitosan pristine fibers have limited biomedical applications because of their poor mechanical properties; although, chitosan composite fibers/synthetic polymer combinations gave better results [279, 317-319]. Electrospun nanofiber mats with chitosan-graft-PCL are promising substitutes for tissue engineering and show excellent cell attachment and proliferation (Table 5) [268, 319].

Hyaluronan/hyaluronic acid is a naturally occurring glycosaminoglycan that constitutes the major components of the ECM, connective tissue, and cartilage [320]. Hyaluronic acid has important applications in wound healing, drug delivery, tissue engineering, and viscosupplementation. It is nonimmunogenic, biodegradable, biocompatible, and has high wettability and the ability to be chemically modified [161]. Electroblowing, electrospinning, and heating synthesise nanofibers from pure hyaluronic acid aqueous solutions [321]. Linking hyaluronic acid with natural polymers forms regular nanofibers that increase its biological performance, whereas conjugating synthetic polymers with hyaluronic acid enhances its electrospinnability and mechanical properties [322, 323]. The bilayered electrospun nanofiber scaffolds of chitosan and hyaluronic acid merged with natural or synthetic polymers are used in wound healing (Table 5) [324, 325].

\section{Fungal polysaccharides}

Fungi synthesise pullulan (an extracellular polysaccharide) and schizophyllan (Sonifilan, SPG) to create electrospun nanofibers. Pullulan is used for the preparation of ultrathin electrospun nanofibers and has massive applications in pharmaceuticals and biomedicine because it is nontoxic, nonmutagenic, tasteless, and odourless [326-329]. Nonetheless, the high hydrophilicity of pullulan hinders its application in tissue engineering, limiting cellular attachment and proliferation and preventing protein 
adsorption. Fortunately, composite scaffolds comprising tissuespecific growth factors, inorganic materials, and ECM proteins, overcome such limitation [330]. Protein-pullulan blends also are reciprocally compatible in electrospun nanofibers [331, 332]. Schizophyllan forms a one-dimensional hydrophobic hollow within its helical superstructure during renaturation; thus, embraces molecular components, functional polymers, and nanoparticles to form water-soluble nanocomposites [333]. Diverse nanocomposites have examined SPG in various biomedical applications: SPG nanoparticles, nanogels, and SPG double network antibacterial hydrogel (Table 5) [334-336].

\section{Bacterial origin polysaccharides}

Bacteria produce polysaccharides for their own aims without interactions with human tissues. Bacterial polymer-based electrospun nanofibers have gained much appreciation in wound healing as they are nonantigenic, histocompatible, and readily washed from the wound area [337]. Dextran (a neutral polymer produced by Lactobacillus spp.) and xanthan gum (an anionic polymer synthesised by Xanthomonas campestris) are common bacterial polysaccharides in wound dressings [338-340]. Due to its hydrophilic nature, the crosslinking of dextran is imperative to tailor its stability against biodegradation and retain its mechanical features in moist conditions. For example, the electrospinning of dextran-boric acid in aqueous solutions prepares a steady network of dextran-boric acid electrospun nanofibers with controlled degradation time. Such network hinders the duration of drug release about $500 \%$ versus pure dextran electrospun nanofibers [341]. Xanthan gum is thermostable and generates self-assembled micro/nanoscale structures in controlled drug delivery, tissue engineering, and regenerative medicine [342]. The internalisation of curcumin into xanthan gum-chitosan electrospun nanofibers improves their stability. The incubation of electrospun nanofibers with Caco- 2 cells monolayers led to almost $80 \%$ of cell viability and enhanced the curcumin transepithelial permeability without menacing the cellular viability in-vitro (Table 5) [343].

\section{Conclusion and future perspectives}

The present review has extensively discussed the current wound healing dressings and demonstrated the advantages and limitations of inorganic nanomaterials, organic and hybrid nanomaterials, and nanofibers in wound healing. Customised wound bandages with nanomaterials offer a vast potential for individualised wound healthcare. Polymeric nanomaterials of natural origin combined with biomolecules, growth factors, and antibiotics could overcome the constraints of the current wound healing materials, producing scaffolds with better mechanical resistance. A hybrid inorganic/natural polymer/antibiotic-based nanocomposite as a combination of antimicrobial and biodegradable nanomaterials could improve wound healing.
One should recognise the major challenges of nanomaterial wound dressings and the mechanism of interaction with the wound to achieve low resistivity and accelerated wound healing. The synthesis of nanomaterials affects their physical stability, mechanical durability, toxicity, and cost. Therefore, structural defects that arise during the production of nanomaterials should be considered. Moreover, the overall manufacturing costs should be reduced to comply with the international health protocols.

Authors' contributions MA: conceptualisation, preparation of the major parts of the manuscript and artwork; MMA: reviewing, writing, editing, and proofreading the manuscript; HS: writing parts of the manuscript, support, and advice during manuscript preparation.

Funding Open access funding provided by The Science, Technology \& Innovation Funding Authority (STDF) in cooperation with The Egyptian Knowledge Bank (EKB).

Availability of data The datasets generated and/or analysed during the current review are available from the corresponding author on a reasonable request.

\section{Declarations}

Competing interests The authors declared that they have no conflicts of interest.

Open Access This article is licensed under a Creative Commons Attribution 4.0 International License, which permits use, sharing, adaptation, distribution and reproduction in any medium or format, as long as you give appropriate credit to the original author(s) and the source, provide a link to the Creative Commons licence, and indicate if changes were made. The images or other third party material in this article are included in the article's Creative Commons licence, unless indicated otherwise in a credit line to the material. If material is not included in the article's Creative Commons licence and your intended use is not permitted by statutory regulation or exceeds the permitted use, you will need to obtain permission directly from the copyright holder. To view a copy of this licence, visit http://creativecommons.org/licenses/by/4.0/.

\section{References}

1. Naskar A, Kim KS (2020) Recent advances in nanomaterialbased wound-healing therapeutics. Pharmaceutics [Internet] 12(6):499. Available from: https://pubmed.ncbi.nlm.nih.gov/ 32486142

2. Ward J, Holden J, Grob M, Soldin M (2019) Management of wounds in the community: five principles. Br J Community Nurs [Internet] 24(Sup6):S20-23. Available from: https://doi.org/10. 12968/bjcn.2019.24.Sup6.S20

3. Nussbaum SR, Carter MJ, Fife CE, DaVanzo J, Haught R, Nusgart M et al (2018) An Economic evaluation of the impact, cost, and medicare policy implications of chronic nonhealing wounds. Value Heal [Internet] 21(1):27-32. Available from: https://www.sciencedirect. com/science/article/pii/S1098301517303297

4. Gong C, Wu Q, Wang Y, Zhang D, Luo F, Zhao X et al (2013) A biodegradable hydrogel system containing curcumin encapsulated 
in micelles for cutaneous wound healing. Biomaterials [Internet] 34(27):6377-6387. Available from: https://www.sciencedirect. com/science/article/pii/S0142961213005590

5. Contardi M, Heredia-Guerrero JA, Perotto G, Valentini P, Pompa PP, Spanò R et al (2017) Transparent ciprofloxacin-povidone antibiotic films and nanofiber mats as potential skin and wound care dressings. Eur J Pharm Sci [Internet] 104:133-144. Available from: https://www.sciencedirect.com/science/article/pii/ S0928098717301793

6. Nguyen TTT, Ghosh C, Hwang S-G, Tran LD, Park JS (2013) Characteristics of curcumin-loaded poly (lactic acid) nanofibers for wound healing. J Mater Sci [Internet] 48(20):7125-7133. Available from: https://doi.org/10.1007/s10853-013-7527-y

7. Aycan D, Selmi B, Kelel E, Yildirim T, Alemdar N (2019) Conductive polymeric film loaded with ibuprofen as a wound dressing material. Eur Polym J [Internet] 121:109308. Available from: https://www.sciencedirect.com/science/article/pii/ S0014305719315940

8. Ng SF, Jumaat N (2014) Carboxymethyl cellulose wafers containing antimicrobials: A modern drug delivery system for wound infections. Eur J Pharm Sci [Internet] 51:173-179. Available from: https://www.sciencedirect.com/science/article/ pii/S0928098713003692

9. Aderibigbe BA, Buyana B (2018) Alginate in wound dressings. Pharmaceutics [Internet] 10(2):42. Available from: https://pubmed.ncbi.nlm.nih.gov/29614804

10. Jones AM, San Miguel L (2006) Are modern wound dressings a clinical and cost-effective alternative to the use of gauze? J Wound Care [Internet] 15(2):65-69. Available from: https://doi. org/10.12968/jowc.2006.15.2.26886

11. Schiavon M, Francescon M, Drigo D, Salloum G, Baraziol $\mathrm{R}$, Tesei J et al (2016) The use of integra dermal regeneration template versus flaps for reconstruction of full-thickness scalp defects involving the calvaria: A cost-benefit analysis. Aesthetic Plast Surg [Internet] 40(6):901-907. Available from: https://pubmed.ncbi.nlm.nih.gov/27699461

12. Dorai AA (2012) Wound care with traditional, complementary and alternative medicine. Indian J Plast Surg [Internet] 45(2):418-424. Available from: https://pubmed.ncbi.nlm. nih.gov/23162243

13. Vandamme L, Heyneman A, Hoeksema H, Verbelen J, Monstrey S (2013) Honey in modern wound care: A systematic review. Burns [Internet] 39(8):1514-1525. Available from: https://www. sciencedirect.com/science/article/pii/S0305417913001976

14. Schencke C, Vasconcellos A, Sandoval C, Torres P, Acevedo F, Del Sol M (2016) Morphometric evaluation of wound healing in burns treated with Ulmo (Eucryphia cordifolia) honey alone and supplemented with ascorbic acid in guinea pig (Cavia porcellus). Burn trauma [Internet] 4:25. Available from: https://pubmed. ncbi.nlm.nih.gov/27730208

15. Lusby PE, Coombes A, Wilkinson JM (2002) Honey: A Potent Agent for Wound Healing? J Wound Ostomy Cont Nurs [Internet] 29(6). Available from: https://journals.lww.com/jwocnonline/ Fulltext/2002/11000/Honey__A_Potent_Agent_for_Wound_ Healing_.8.aspx

16. Eteraf-Oskouei T, Najafi M (2013) Traditional and modern uses of natural honey in human diseases: a review. Iran J Basic Med Sci [Internet] 16(6):731-742. Available from: https://pubmed. ncbi.nlm.nih.gov/23997898

17. Borena BM, Martens A, Broeckx SY, Meyer E, Chiers K, Duchateau L, Spaas JH (2015) Regenerative Skin Wound Healing in Mammals: State-of-the-Art on Growth Factor and Stem Cell Based Treatments. Cell Physiol Biochem [Internet] 36(1):1-23. Available from: https://www.karger.com/DOI/10. $1159 / 000374049$
18. Frykberg RG, Banks J (2015) Challenges in the treatment of chronic wounds. Adv Wound Care [Internet] 4(9):560-82. Available from: https://pubmed.ncbi.nlm.nih.gov/26339534

19. Tocco I, Zavan B, Bassetto F, Vindigni V (2012) Nanotechnology-Based Therapies for Skin Wound Regeneration. Li X, editor. J Nanomater [Internet] 2012:714134. Available from: https://doi. org/10.1155/2012/714134

20. Kalashnikova I, Das S, Seal S (2015) Nanomaterials for wound healing: scope and advancement. Nanomedicine [Internet] 10(16):2593-612. Available from: https://doi.org/10.2217/nnm.15.82

21. Hamdan S, Pastar I, Drakulich S, Dikici E, Tomic-Canic M, Deo $S$ et al (2017) Nanotechnology-driven therapeutic interventions in wound healing: Potential uses and applications. ACS Cent Sci [Internet] 3(3):163-75. Available from: https://pubmed.ncbi.nlm. nih.gov/28386594

22. Mihai MM, Dima MB, Dima B, Holban AM (2019) Nanomaterials for wound healing and infection control. Mater (Basel, Switzerland) [Internet] 12(13):2176. Available from: https://pubmed. ncbi.nlm.nih.gov/31284587

23. Pal S, Nisi R, Stoppa M, Licciulli A (2017) Silver-functionalized bacterial cellulose as antibacterial membrane for wound-healing applications. ACS Omega [Internet] 2(7):3632-9. Available from: https://doi.org/10.1021/acsomega.7b00442

24. Radulescu M, Andronescu E, Dolete G, Popescu RC, Fufă O, Chifiriuc MC et al (2016) Silver nanocoatings for reducing the exogenous microbial colonization of wound dressings. Mater (Basel, Switzerland) [Internet] 9(5):345. Available from: https:// pubmed.ncbi.nlm.nih.gov/28773468

25. Sood A, Granick MS, Tomaselli NL (2014) Wound dressings and comparative effectiveness data. Adv wound care [Internet] 3(8):511-29. Available from: https://pubmed.ncbi.nlm.nih. gov/25126472

26. Rosenbaum AJ, Banerjee S, Rezak KM, Uhl RL (2018) Advances in wound management. JAAOS - J Am Acad Orthop Surg [Internet] 26(23). Available from: https://journals.lww.com/jaaos/Fullt ext/2018/12010/Advances_in_Wound_Management.3.aspx

27. Sarabahi S (2012) Recent advances in topical wound care. Indian J Plast Surg [Internet] 45(2):379-87. Available from: https://pubmed.ncbi.nlm.nih.gov/23162238

28. Doerries C, Grote K, Hilfiker-Kleiner D, Luchtefeld M, Schaefer A, Holland SM et al (2007) Critical Role of the NAD(P)H Oxidase Subunit p47phox for Left Ventricular Remodeling/Dysfunction and Survival After Myocardial Infarction. Circ Res [Internet] 100(6):894-903. Available from: https://doi.org/10.1161/01. RES.0000261657.76299.ff

29. Bell D, Hyam D (2007) Choosing an appropriate dressing for chronic wounds. Prescriber [Internet] 18(11):65-70. Available from: https:// www.onlinelibrary.wiley.com/doi/full/10.1002/psb.89

30. Graça MFP, Miguel SP, Cabral CSD, Correia IJ (2020) Hyaluronic acid-Based wound dressings: A review. Carbohydr Polym [Internet]. 241:116364. Available from: https://www.sciencedir ect.com/science/article/pii/S0144861720305385

31. Das S, Singh A, Singh L, Sinam N, Singh S (2020) A comparative clinical study of collagen and paraffin gauze dressing on skin donor site. J Med Soc [Internet] 34(3):162-6. Available from: https://www.jmedsoc.org/article.asp?issn=0972-4958

32. Bleasdale B, Finnegan S, Murray K, Kelly S, Percival SL (2015) The Use of Silicone Adhesives for Scar Reduction. Adv wound care [Internet] 4(7):422-30. Available from: https://pubmed.ncbi. nlm.nih.gov/26155385

33. Hansson C (1997) Interactive wound dressings. Drugs Aging [Internet] 11(4):271-84. Available from: https://doi.org/10.2165/ 00002512-199711040-00003

34. Dhivya S, Padma VV, Santhini E (2015) Wound dressings - a review. BioMedicine [Internet] 5(4):22. Available from: https:// pubmed.ncbi.nlm.nih.gov/26615539 
35. Anisha BS, Sankar D, Mohandas A, Chennazhi KP, Nair SV, Jayakumar R (2013) Chitosan-hyaluronan/nano chondroitin sulfate ternary composite sponges for medical use. Carbohydr Polym [Internet] 92(2):1470-6. Available from: https://www. sciencedirect.com/science/article/pii/S0144861712010867

36. Gupta KC, Haider A, Choi Y-R, Kang IK (2014) Nanofibrous scaffolds in biomedical applications. Biomater Res [Internet] 18:5. Available from: https://pubmed.ncbi.nlm.nih.gov/26331056

37. Colobatiu L, Gavan A, Mocan A, Bogdan C, Mirel S, Tomuta I (2019) Development of bioactive compounds-loaded chitosan films by using a QbD approach - A novel and potential wound dressing material. React Funct Polym [Internet] 138:46-54. Available from: https:// www.sciencedirect.com/science/article/pii/S1381514819300227

38. Jeon IY, Baek JB (2010) Nanocomposites derived from polymers and inorganic nanoparticles. Materials (Basel) [Internet] 3(6):3654-74. Available from: https://www.ncbi.nlm.nih.gov/ pmc/articles/PMC5521759/

39. Jafari A, Hassanajili S, Karimi MB, Emami A, Ghaffari F, Azarpira N (2018) Effect of organic/inorganic nanoparticles on performance of polyurethane nanocomposites for potential wound dressing applications. J Mech Behav Biomed Mater [Internet] 88:395-405. Available from: https://www.sciencedirect.com/ science/article/pii/S1751616118309081

40. Wang X, Chang J, Wu C (2018) Bioactive inorganic/organic nanocomposites for wound healing. Appl Mater Today [Internet] 11:308-19. Available from: https://www.sciencedirect.com/ science/article/pii/S2352940718300477

41. Yang X, Yang J, Wang L, Ran B, Jia Y, Zhang L et al (2017) Pharmaceutical intermediate-modified gold nanoparticles: Against multidrug-resistant bacteria and wound-healing application via an Electrospun Scaffold. ACS Nano [Internet] 11(6):5737-45. Available from: https://doi.org/10.1021/acsnano.7b01240

42. Hazer DB, Sakar M, Dere Y, Altinkanat G, Ziyal MI, Hazer B (2016) Antimicrobial effect of polymer-based silver nanoparticle coated pedicle screws: experimental research on biofilm inhibition in rabbits. Spine (Phila Pa 1976) [Internet] 41(6). Available from: https://www.journals.lww.com/spinejournal/Fulltext/2016/ 03150/Antimicrobial_Effect_of_Polymer_Based_Silver.4.aspx

43. Hazer DB, Hazer B, Dinçer N (2011) Soft tissue response to the presence of polypropylene-G-poly(ethylene glycol) comb-type graft copolymers containing gold nanoparticles. J Biomed Biotechnol [Internet] 2011:956169. Available from: https://pubmed. ncbi.nlm.nih.gov/22235166

44. Hazer Rosberg DB, Hazer B, Stenberg L, Dahlin LB (2021) Gold and cobalt oxide nanoparticles modified poly-propylene polyethylene glycol membranes in poly ( $\varepsilon$-caprolactone) conduits enhance nerve regeneration in the sciatic nerve of healthy rats. Vol 22, Int J Mol Sci

45. Hazer DB, Hazer B (2011) The effect of gold clusters on the autoxidation of poly(3-hydroxy 10-undecenoate-co-3-hydroxy octanoate) and tissue response evaluation. J Polym Res [Internet] 18(2):251-62. Available from: https://doi.org/10.1007/ s10965-010-9413-5

46. Şevik Eliçora S, Erdem D, Dinç AE, Altunordu Kalaycı Ö, Hazer B, Yurdakan G et al (2017) Effects of polymer-based, silver nanoparticle-coated silicone splints on the nasal mucosa of rats. Eur Arch Oto-Rhino-Laryngology [Internet] 274(3):1535-41. Available from: https://doi.org/10.1007/s00405-016-4394-6

47. Erol A, Rosberg DBH, Hazer B, Göncü BS (2020) Biodegradable and biocompatible radiopaque iodinated poly-3-hydroxy butyrate: synthesis, characterization and in vitro/in vivo $\mathrm{X}$-ray visibility. Polym Bull [Internet] 77(1):275-89. Available from: https://doi.org/10.1007/s00289-019-02747-6

48. Hazer B, Akyol E (2016) Efficiency of gold nano particles on the autoxidized soybean oil polymer: Fractionation and structural analysis. J Am Oil Chem Soc [Internet] 93(2):20113. Available from: https://doi.org/10.1007/s11746-015-2764-7

49. Karahaliloglu Z, Kilicay E, Hazer B (2020) PLinaS-g-PEG coated magnetic nanoparticles as a contrast agent for hepatocellular carcinoma diagnosis. J Biomater Sci Polym Ed [Internet] 31(12):1580-603. Available from: https://doi.org/10.1080/ 09205063.2020.1764183

50. Kilic MS, Korkut S, Hazer B, Erhan E (2014) Development and operation of gold and cobalt oxide nanoparticles containing polypropylene based enzymatic fuel cell for renewable fuels. Biosens Bioelectron [Internet] 61:500-5. Available from: https://www.sciencedirect.com/science/article/pii/ S0956566314004163

51. Köroğlu A, Şahin O, Kürkçüoğlu I, Dede DÖ, Özdemir T, Hazer B (2016) Silver nanoparticle incorporation effect on mechanical and thermal properties of denture base acrylic resins. J Appl Oral Sci [Internet] 24(6):590-6. Available from: https://pubmed.ncbi. nlm.nih.gov/28076464

52. Korkut S, Uzuncar S, Kilic MS, Hazer B (2016) Electrochemical, continuous-flow determination of p-benzoquinone on a gold nanoparticles poly(propylene-co-imidazole) modified gold electrode. Instrum Sci Technol [Internet] 44(6):614-28. Available from: https://doi.org/10.1080/10739149.2016.1184161

53. Ninan N, Muthiah M, Park I-K, Wong TW, Thomas S, Grohens Y (2015) Natural polymer/inorganic material based hybrid scaffolds for skin wound healing. Polym Rev [Internet] 55(3):453-90. Available from: https://doi.org/10.1080/15583724.2015.1019135

54. Zhong SP, Zhang YZ, Lim CT (2010) Tissue scaffolds for skin wound healing and dermal reconstruction. WIREs Nanomedicine and Nanobiotechnology [Internet] 2(5):510-25. Available from: https://doi.org/10.1002/wnan.100

55. Zare Y, Shabani I (2016) Polymer/metal nanocomposites for biomedical applications. Mater Sci Eng C [Internet]. 60:195-203. Available from: https://www.sciencedirect.com/science/article/ pii/S0928493115305543

56. Parani M, Lokhande G, Singh A, Gaharwar AK (2016) Engineered nanomaterials for infection control and healing acute and chronic wounds. ACS Appl Mater Interfaces [Internet]. 8(16):10049-69. Available from: https://doi.org/10.1021/acsami.6b00291

57. Gaharwar AK, Peppas NA, Khademhosseini A (2014) Nanocomposite hydrogels for biomedical applications. Biotechnol Bioeng [Internet] 111(3):441-53. Available from: https://doi. org/10.1002/bit.25160

58. Khan I, Saeed K, Khan I (2019) Nanoparticles: properties, applications and toxicities. Arab J Chem [Internet] 12(7):908-31. Available from: https://www.sciencedirect.com/science/article/ pii/S1878535217300990

59. Rajendran NK, Kumar SSD, Houreld NN, Abrahamse H (2018) A review on nanoparticle based treatment for wound healing. J Drug Deliv Sci Technol [Internet] 44:421-30. Available from: https:// www.sciencedirect.com/science/article/pii/S1773224717308523

60. Maas M (2016) Carbon nanomaterials as antibacterial colloids. Mater (Basel, Switzerland) [Internet] 9(8):617. Available from: https://pubmed.ncbi.nlm.nih.gov/28773737

61. Zhou Z, Joslin S, Dellinger A, Ehrich M, Brooks B, Ren Q et al (2010) A novel class of compounds with cutaneous wound healing properties [Internet]. J Biomed Nanotechnol Vol 6:p 605611. Available from: https://www.ingentaconnect.com/content/ asp/jbn/2010/00000006/00000005/art00016

62. Kumar N, Kumbhat S (2016) Carbon-based nanomaterials [Internet]. Essentials in nanoscience and nanotechnology 189-236 p (Wiley Online Books). Available from: https://doi.org/10.1002/ 9781119096122.ch5

63. Triesscheijn M, Ruevekamp M, Aalders M, Baas P, Stewart FA (2005) Outcome of mTHPC mediated photodynamic therapy is primarily determined by the vascular response. Photochem 
Photobiol [Internet] 81(5):1161-7. Available from: https://doi. org/10.1562/2005-04-04-RA-474

64. Salimi F, Mohammadipanah F (2021) Nanomaterials versus the microbial compounds with wound healing property [Internet]. Front Nanotechnol Vol 2:p 21. Available from: https://www.front iersin.org/article/10.3389/fnano.2020.584489

65. Sundaram P, Abrahamse H (2020) Phototherapy combined with carbon nanomaterials (1D and 2D) and their applications in cancer therapy. Mater (Basel, Switzerland) [Internet] 13(21):4830. Available from: https://www.pubmed.ncbi.nlm.nih.gov/33126750

66. Jia G, Wang H, Yan L, Wang X, Pei R, Yan T et al (2005) Cytotoxicity of carbon nanomaterials: single-wall nanotube, multi-wall nanotube, and fullerene. Environ Sci Technol [Internet] 39(5):1378-83. Available from: https://doi.org/10.1021/es0487291

67. Yang K, Li Y, Tan X, Peng R, Liu Z (2013) Behavior and toxicity of graphene and its functionalized derivatives in biological systems. Small [Internet] 9(9-10):1492-503. Available from: https://doi.org/10.1002/smll.201201417

68. Monteiro-Riviere NA, Nemanich RJ, Inman AO, Wang YY, Riviere JE (2005) Multi-walled carbon nanotube interactions with human epidermal keratinocytes. Toxicol Lett [Internet] 155(3):377-84. Available from: https://www.sciencedirect. com/science/article/pii/S0378427404005065

69. Jacobsen NR, Pojana G, White P, Møller P, Cohn CA, Smith Korsholm K et al (2008) Genotoxicity, cytotoxicity, and reactive oxygen species induced by single-walled carbon nanotubes and C60 fullerenes in the FE1-Muta ${ }^{\mathrm{TM}}$ Mouse lung epithelial cells. Environ Mol Mutagen [Internet] 49(6):476-87. Available from: https://doi.org/10.1002/em.20406

70. Pulskamp K, Diabaté S, Krug HF (2007) Carbon nanotubes show no sign of acute toxicity but induce intracellular reactive oxygen species in dependence on contaminants. Toxicol Lett [Internet] 168(1):58-74. Available from: https://www.sciencedirect. com/science/article/pii/S0378427406013178

71. Liao KH, Lin YS, Macosko CW, Haynes CL (2011) Cytotoxicity of graphene oxide and graphene in human erythrocytes and skin fibroblasts. ACS Appl Mater Interfaces [Internet]. 3(7):2607-15. Available from: https://doi.org/10.1021/am200428v

72. Mauter MS, Elimelech M (2008) Environmental Applications of Carbon-Based Nanomaterials. Environ Sci Technol [Internet] 42(16):5843-59. Available from: https://doi.org/10.1021/ es8006904

73. Geim AK, Novoselov KS (2007) The rise of graphene. Nat Mater [Internet] 6(3):183-91. Available from: https://doi.org/10.1038/ nmat1849

74. NPG Asia Materials (2008) Graphene: beaming features. NPG Asia Mater [Internet]. Available from: https://doi.org/10.1038/ asiamat.2008.171

75. Yu G, Hu L, Vosgueritchian M, Wang H, Xie X, McDonough JR et al (2011) Solution-processed graphene/MnO2 nanostructured textiles for high-performance electrochemical capacitors. Nano Lett [Internet] 11(7):2905-11. Available from: https://doi.org/ $10.1021 / \mathrm{nl} 2013828$

76. Liu S, Zeng TH, Hofmann M, Burcombe E, Wei J, Jiang R et al Antibacterial activity of graphite, graphite oxide, graphene oxide, and reduced graphene oxide: membrane and oxidative stress. ACS Nano [Internet] 5(9):6971-80. Available from: https://doi. org/10.1021/nn202451x

77. Gurunathan S, Han JW, Dayem AA, Eppakayala V, Kim JH (2012) Oxidative stress-mediated antibacterial activity of graphene oxide and reduced graphene oxide in Pseudomonas aeruginosa. Int J Nanomedicine [Internet] 7:5901-14. Available from: https://pubmed.ncbi.nlm.nih.gov/23226696

78. Krishnamoorthy K, Umasuthan N, Mohan R, Lee J, Kim SJ (2012) Antibacterial Activity of Graphene Oxide Nanosheets [Internet]. Sci Adv Mater Vol 4:p 1111-1117.
Available from: https://www.ingentaconnect.com/content/asp/ sam/2012/00000004/00000011/art00002

79. Lu B, Li T, Zhao H, Li X, Gao C, Zhang S et al (2012) Graphene-based composite materials beneficial to wound healing. Nanoscale [Internet] 4(9):2978-82 Available from: https://doi.org/10.1039/C2NR11958G

80. Zheng Y, Li S, Han D, Kong L, Wang J, Zhao M et al (2021) Eco-friendly preparation of epoxy-rich graphene oxide for wound healing. ACS Biomater Sci Eng [Internet] 7(2):752-63. Available from: https://doi.org/10.1021/acsbiomaterials.0c01598

81. Khan MS, Abdelhamid HN, Wu HF (2015) Near infrared (NIR) laser mediated surface activation of graphene oxide nanoflakes for efficient antibacterial, antifungal and wound healing treatment. Colloids Surfaces B Biointerfaces [Internet] 127:281-91. Available from: https://www.sciencedirect.com/science/article/ pii/S092777651400736X

82. De Vrieze S, Westbroek P, Van Camp T, Van Langenhove L (2007) Electrospinning of chitosan nanofibrous structures: feasibility study. J Mater Sci [Internet] 42(19):8029-34. Available from: https://doi.org/10.1007/s10853-006-1485-6

83. Chen Z, Mo X, He C, Wang H (2008) Intermolecular interactions in electrospun collagen-chitosan complex nanofibers. Carbohydr Polym [Internet] 72(3):410-8. Available from: https://www.scien cedirect.com/science/article/pii/S0144861707004857

84. Ignatova M, Manolova N, Rashkov I (2007) Novel antibacterial fibers of quaternized chitosan and poly(vinyl pyrrolidone) prepared by electrospinning. Eur Polym J [Internet] 43(4):11121122. Available from: https://www.sciencedirect.com/science/ article/pii/S0014305707000250

85. Bhattarai N, Edmondson D, Veiseh O, Matsen FA, Zhang M (2005) Electrospun chitosan-based nanofibers and their cellular compatibility. Biomaterials [Internet] 26(31):6176-6184 Available from: https://www.sciencedirect.com/science/article/pii/ S0142961205002620

86. Desai K, Kit K, Li J, Michael Davidson P, Zivanovic S, Meyer H (2009) Nanofibrous chitosan non-wovens for filtration applications. Polymer (Guildf) [Internet] 50(15):3661-3669 Available from: https://www.sciencedirect.com/science/article/pii/S0032 38610900456X

87. Jayakumar R, Prabaharan M, Nair S V, Tamura H (2010) Novel chitin and chitosan nanofibers in biomedical applications. Biotechnol Adv [Internet] 28(1):142-50. Available from: https:// www.sciencedirect.com/science/article/pii/S0734975009001852

88. Yang Y, Dong Z, Li M, Liu L, Luo H, Wang P et al (2020) Graphene oxide/copper nanoderivatives-modified chitosan/hyaluronic acid dressings for facilitating wound healing in infected full-thickness skin defects. Int J Nanomedicine [Internet] 15:8231-8247 Available from: https://pubmed.ncbi.nlm.nih.gov/33149572

89. Lasocka I, Jastrzębska E, Szulc-Dąbrowska L, Skibniewski M, Pasternak I, Kalbacova MH et al The effects of graphene and mesenchymal stem cells in cutaneous wound healing and their putative action mechanism. Int J Nanomedicine [Internet] 14:22812299 Available from: https://pubmed.ncbi.nlm.nih.gov/31015759

90. Liu L, Qing M, Wang Y, Chen S (2015) Defects in graphene: generation, healing, and their effects on the properties of graphene: A Review. J Mater Sci Technol [Internet] 31(6):599-606. Available from: https://www.sciencedirect.com/science/article/ pii/S100503021500016X

91. Eckmann A, Felten A, Mishchenko A, Britnell L, Krupke R, Novoselov KS et al (2012) Probing the nature of defects in graphene by raman spectroscopy. Nano Lett [Internet] 12(8):39253930 Available from: https://doi.org/10.1021/nl300901a

92. Poland CA, Duffin R, Kinloch I, Maynard A, Wallace WAH, Seaton A et al (2008) Carbon nanotubes introduced into the abdominal cavity of mice show asbestos-like pathogenicity in a 
pilot study. Nat Nanotechnol [Internet] 3(7):423-428 Available from: https://doi.org/10.1038/nnano.2008.111

93. Porter AE, Gass M, Muller K, Skepper JN, Midgley PA, Welland M (2007) Direct imaging of single-walled carbon nanotubes in cells. Nat Nanotechnol [Internet] 2(11):713-717. Available from: https://doi.org/10.1038/nnano.2007.347

94. Rada BK, Geiszt M, Káldi K, Timár C, Ligeti E (2004) Dual role of phagocytic NADPH oxidase in bacterial killing. Blood [Internet] 104(9):2947-2953. Available from: https://www.sciencedirect. com/science/article/pii/S0006497120559715

95. Kang S, Herzberg M, Rodrigues DF, Elimelech M (2008) Antibacterial effects of carbon nanotubes: size does matter! langmuir [Internet] 24(13):6409-6413. Available from: https://doi.org/10.1021/ la800951v

96. Oyelami AO, Semple KT (2015) Impact of carbon nanomaterials on microbial activity in soil. Soil Biol Biochem [Internet] 86:172-180 Available from: https://www.sciencedirect.com/ science/article/pii/S0038071715001418

97. Kittana N, Assali M, Abu-Rass H, Lutz S, Hindawi R, Ghannam L et al (2018) Enhancement of wound healing by single-wall/multiwall carbon nanotubes complexed with chitosan. Int J Nanomedicine [Internet] 13:7195-7206 Available from: https://pubmed.ncbi. nlm.nih.gov/30510412

98. Banihashemi K, Amirmozafari N, Mehregan I, Bakhtiari R, Sobouti B (2021) Antibacterial effect of carbon nanotube containing chemical compounds on drug-resistant isolates of Acinetobacter baumannii. Iran J Microbiol [Internet] 13(1):112-120. Available from: https://pubmed.ncbi.nlm.nih.gov/33889370

99. Niu A, Han Y, Wu J, Yu N, Xu Q (2010) Synthesis of one-dimensional carbon nanomaterials wrapped by silver nanoparticles and their antibacterial behavior. J Phys Chem C [Internet] 114(29):12728-12735 Available from: https://doi.org/10.1021/jp104720w

100. Akhavan O, Abdolahad M, Abdi Y, Mohajerzadeh S (2009) Synthesis of titania/carbon nanotube heterojunction arrays for photoinactivation of E. coli in visible light irradiation. Carbon N Y [Internet] 47(14):3280-3287. Available from: https://www. sciencedirect.com/science/article/pii/S0008622309004813

101. Su Y, Zheng X, Chen A, Chen Y, He G, Chen H (2015) Hydroxyl functionalization of single-walled carbon nanotubes causes inhibition to the bacterial denitrification process. Chem Eng J [Internet] 279:47-55. Available from: https://www.sciencedirect.com/ science/article/pii/S1385894715006567

102. Liao JL, Zhong S, Wang SH, Liu JY, Chen J, He G et al (2017) Preparation and properties of a novel carbon nanotubes/ poly(vinyl alcohol)/epidermal growth factor composite biological dressing. Exp Ther Med [Internet] 14(3):2341-8. Available from: https://pubmed.ncbi.nlm.nih.gov/28962165

103. Luanpitpong S, Wang L, Rojanasakul Y (2014) The effects of carbon nanotubes on lung and dermal cellular behaviors. Nanomedicine (Lond) [Internet] 9(6):895-912. Available from: https://pubmed.ncbi.nlm.nih.gov/24981653

104. Zhang Y, Wang B, Meng X, Sun G, Gao C (2011) Influences of acid-treated multiwalled carbon nanotubes on fibroblasts: Proliferation, adhesion, migration, and wound healing. Ann Biomed Eng [Internet] 39(1):414-26. Available from: https://doi.org/10. 1007/s10439-010-0151-y

105. Palmer BC, Phelan-Dickenson SJ, DeLouise LA (2019) Multi-walled carbon nanotube oxidation dependent keratinocyte cytotoxicity and skin inflammation. Part Fibre Toxicol [Internet] 16(1):3. Available from: https://doi.org/10.1186/ s12989-018-0285-X

106. Lyon DY, Fortner JD, Sayes CM, Colvin VL, Hughes JB (2005) Bacterial cell association and antimicrobial activity of a C60 water suspension. Environ Toxicol Chem [Internet] 24(11):275762. Available from: https://doi.org/10.1897/04-649R.1
107. Lyon DY, Adams LK, Falkner JC, Alvarez PJJ (2006) Antibacterial activity of fullerene water suspensions: effects of preparation method and particle size. Environ Sci Technol [Internet] 40(14):4360-6. Available from: https://doi.org/10.1021/es0603655

108. Lyon DY, Brunet L, Hinkal GW, Wiesner MR, Alvarez PJJ (2008) Antibacterial activity of fullerene water suspensions (nC60) is not due to ROS-mediated damage. Nano Lett [Internet] 8(5):1539-43. Available from: https://doi.org/10.1021/n10726398

109. Fang J, Lyon DY, Wiesner MR, Dong J, Alvarez (2007) Effect of a fullerene water suspension on bacterial phospholipids and membrane phase behavior. Environ Sci Technol [Internet] 41(7):2636-2642. Available from: https://doi.org/10.1021/es062181w

110. Zhang J, Xu J, Ma H, Bai H, Liu L, Shu C et al (2019) Designing an amino-fullerene derivative C70-(EDA)8 to fight superbacteria. ACS Appl Mater Interfaces [Internet] 11(16):14597-607. Available from: https://doi.org/10.1021/acsami.9b01483

111. Man HB, Ho D (2012) Diamond as a nanomedical agent for versatile applications in drug delivery, imaging, and sensing. Phys status solidi [Internet] 209(9):1609-1618. Available from: https://doi.org/10.1002/pssa.201200470

112. Whitlow J, Pacelli S, Paul A (2017) Multifunctional nanodiamonds in regenerative medicine: Recent advances and future directions. J Control Release [Internet] 261:62-86. Available from: https://pubmed.ncbi.nlm.nih.gov/28596105

113. Smith AH, Robinson EM, Zhang XQ, Chow EK, Lin Y, Osawa E et al (2011) Triggered release of therapeutic antibodies from nanodiamond complexes. Nanoscale [Internet] 3(7):2844-8. Available from: https://pubmed.ncbi.nlm.nih.gov/21617824

114. Vaijayanthimala V, Chang HC (2008) Functionalized fluorescent nanodiamonds for biomedical applications. Nanomedicine [Internet] 4(1):47-55. Available from: https://doi.org/10.2217/ 17435889.4.1.47

115. Namdar R, Nafisi S (2018) Nanodiamond applications in skin preparations. Drug Discov Today [Internet] 23(5):1152-1158. Available from: https://www.sciencedirect.com/science/article/ pii/S1359644617304117

116. Ansari SA, Satar R, Jafri MA, Rasool M, Ahmad W, Kashif Zaidi S (2016) Role of nanodiamonds in drug delivery and stem cell therapy. Iran J Biotechnol [Internet] 14(3):130-41. Available from: https://pubmed.ncbi.nlm.nih.gov/28959329

117. Pacelli S, Acosta F, Chakravarti AR, Samanta SG, Whitlow J, Modaresi S et al (2017) Nanodiamond-based injectable hydrogel for sustained growth factor release: Preparation, characterization and in vitro analysis. Acta Biomater [Internet] 58:479-491. Available from: https://pubmed.ncbi.nlm.nih.gov/28532899

118. Luo X, Zhang H, Cao Z, Cai N, Xue Y, Yu F (2016) A simple route to develop transparent doxorubicin-loaded nanodiamonds/ cellulose nanocomposite membranes as potential wound dressings. Carbohydr Polym [Internet] 143:231-238. Available from: https:// www.sciencedirect.com/science/article/pii/S0144861716300406

119. Ostadhossein F, Mahmoudi N, Morales-Cid G, Tamjid E, NavasMartos FJ, Soriano-Cuadrado B et al (2015) Development of chitosan/bacterial cellulose composite films containing nanodiamonds as a potential flexible platform for wound dressing. Mater (Basel, Switzerland) [Internet] 8(9):6401-6418. Available from: https://pubmed.ncbi.nlm.nih.gov/28793571

120. Mahdavi M, Mahmoudi N, Rezaie Anaran F, Simchi A (2016) Electrospinning of nanodiamond-modified polysaccharide nanofibers with physico-mechanical properties close to natural skins. Mar Drugs [Internet] 14(7):128. Available from: https:// pubmed.ncbi.nlm.nih.gov/27399726

121. Marciano FR, Bonetti LF, Da-Silva NS, Corat EJ, Trava-Airoldi VJ (2009) Diamond-like carbon films produced from high deposition rates exhibit antibacterial activity. Synth Met [Internet] 159(21):21672169. Available from: https://www.sciencedirect.com/science/article/ pii/S0379677909004019 
122. Marciano FR, Bonetti LF, Da-Silva NS, Corat EJ, Trava-Airoldi VJ (2009) Wettability and antibacterial activity of modified diamond-like carbon films. Appl Surf Sci [Internet] 255(20):83778382. Available from: https://www.sciencedirect.com/science/ article/pii/S0169433209007193

123. Marciano FR, Bonetti LF, Mangolin JF, Da-Silva NS, Corat EJ, Trava-Airoldi VJ (2011) Investigation into the antibacterial property and bacterial adhesion of diamond-like carbon films. Vacuum [Internet] 85(6):662-666. Available from: https://www. sciencedirect.com/science/article/pii/S0042207X10003143

124. Jelinek M, Voss A, Kocourek T, Mozafari M, Vymětalová V, Zezulová M et al (2013) Comparison of the surface properties of DLC and ultrananocrystalline diamond films with respect to their bio-applications. Phys status solidi [Internet] 210(10):21062110. Available from: https://doi.org/10.1002/pssa.201228713

125. Robertson J (2002) Diamond-like amorphous carbon. Mater Sci Eng R Reports [Internet] 37(4):129-281. Available from: https:// www.sciencedirect.com/science/article/pii/S0927796X02000050

126. Hauert R, Thorwarth G, Müller U, Stiefel M, Falub C V, Thorwarth K et al (2012) Analysis of the in-vivo failure of the adhesive interlayer for a DLC coated articulating metatarsophalangeal joint. Diam Relat Mater [Internet] 25:3439. Available from: https://www.sciencedirect.com/science/ article/pii/S0925963512000568

127. Hauert R, Falub C V, Thorwarth G, Thorwarth K, Affolter C, Stiefel M et al (2012) Retrospective lifetime estimation of failed and explanted diamond-like carbon coated hip joint balls. Acta Biomater [Internet] 8(8):3170-3176. Available from: https:// www.sciencedirect.com/science/article/pii/S1742706112001638

128. Lopes FS, Oliveira JR, Milani J, Oliveira LD, Machado JPB, Trava-Airoldi VJ et al (2017) Biomineralized diamond-like carbon films with incorporated titanium dioxide nanoparticles improved bioactivity properties and reduced biofilm formation. Mater Sci Eng C [Internet] 81:373-379. Available from: https:// www.sciencedirect.com/science/article/pii/S0928493117318283

129. Kinnari TJ, Soininen A, Esteban J, Zamora N, Alakoski E, Kouri VP et al (2008) Adhesion of staphylococcal and Caco-2 cells on diamond-like carbon polymer hybrid coating. J Biomed Mater Res Part A [Internet] 86A(3):760-768. Available from: https:// doi.org/10.1002/jbm.a.31643

130. AlBuhairan B, Hind D, Hutchinson A (2008) Hutchinson Antibiotic prophylaxis for wound infections in total joint arthroplasty. $\mathrm{J}$ Bone Joint Surg Br [Internet] 90-B(7):915-919 Available from: https://doi.org/10.1302/0301-620X.90B7.20498

131. Hauert R (2003) A review of modified DLC coatings for biological applications. Diam Relat Mater [Internet] 12(3):583-589. Available from: https://www.sciencedirect.com/science/article/ pii/S0925963503000815

132. Juknius T, Ružauskas M, Tamulevičius T, Šiugždinienè R, Juknienè I, Vasiliauskas A et al (2016) Antimicrobial properties of diamond-like carbon/silver nanocomposite thin films deposited on textiles: towards smart bandages. Mater (Basel, Switzerland) [Internet] 9(5):371. Available from: https://pubmed.ncbi.nlm.nih.gov/28773494

133. Gorzelanny C, Kmeth R, Obermeier A, Bauer AT, Halter N, Kümpel K et al (2016) Silver nanoparticle-enriched diamondlike carbon implant modification as a mammalian cell compatible surface with antimicrobial properties. Sci Rep [Internet] 6:22849. Available from: https://pubmed.ncbi.nlm.nih.gov/26955791

134. Wachesk CC, Seabra SH, Dos Santos TAT, Trava-Airoldi VJ, Lobo AO, Marciano FR (2021) In vivo biocompatibility of diamondlike carbon films containing $\mathrm{TiO}(2)$ nanoparticles for biomedical applications. J Mater Sci Mater Med [Internet] 32(9):117. Available from: https://pubmed.ncbi.nlm.nih.gov/34460018

135. Pereira RF, Bártolo PJ (2016) Traditional therapies for skin wound healing. Adv Wound Care [Internet]. 5(5):208-229. Available from: https://pubmed.ncbi.nlm.nih.gov/27134765
136. Jiao M, Zhang P, Meng J, Li Y, Liu C, Luo X et al (2018) Recent advancements in biocompatible inorganic nanoparticles towards biomedical applications. Biomater Sci [Internet] 6(4):726-745. Available from: https://doi.org/10.1039/C7BM01020F

137. Naskar A, Kim K (2019) Black phosphorus nanomaterials as multi-potent and emerging platforms against bacterial infections. Microb Pathog [Internet] 137:103800. Available from: https:// www.sciencedirect.com/science/article/pii/S0882401019310678

138. Naskar A, Khan H, Sarkar R, Kumar S, Halder D, Jana S (2018) Anti-biofilm activity and food packaging application of room temperature solution process based polyethylene glycol capped Ag-ZnO-graphene nanocomposite. Mater Sci Eng C [Internet] 91:743-753. Available from: https://www.sciencedirect. com/science/article/pii/S0928493117334033

139. Naskar A, Lee S, Kim K (2020) Antibacterial potential of Nidoped zinc oxide nanostructure: comparatively more effective against Gram-negative bacteria including multi-drug resistant strains. RSC Adv [Internet] 10(3):1232-1242. Available from: https://doi.org/10.1039/C9RA09512H

140. Khan MS, Bhaisare ML, Gopal J, Wu HF (2016) Highly efficient gold nanorods assisted laser phototherapy for rapid treatment on mice wound infected by pathogenic bacteria. J Ind Eng Chem [Internet] 36:49-58. Available from: https://www.sciencedirect. com/science/article/pii/S1226086X15005596

141. Millenbaugh NJ, Baskin JB, DeSilva MN, Elliott WR, Glickman RD (2015) Photothermal killing of staphylococcus aureus using antibody-targeted gold nanoparticles. Int J Nanomedicine [Internet] 10:1953-1960. Available from: https://pubmed.ncbi.nlm.nih. gov/25834427

142. Kirui DK, Weber G, Talackine J, Millenbaugh NJ (2019) Targeted laser therapy synergistically enhances efficacy of antibiotics against multi-drug resistant Staphylococcus aureus and Pseudomonas aeruginosa biofilms. Nanomedicine Nanotechnology, Biol Med [Internet] 20:102018. Available from: https://www. sciencedirect.com/science/article/pii/S1549963419301029

143. Nasrabadi HT, Abbasi E, Davaran S, Kouhi M, Akbarzadeh A (2016) Bimetallic nanoparticles: Preparation, properties, and biomedical applications. Artif Cells, Nanomedicine, Biotechnol [Internet] 44(1):376-380. Available from: https://doi.org/10. 3109/21691401.2014.953632

144. Burdușel A-C, Gherasim O, Grumezescu AM, Mogoantă L, Ficai A, Andronescu E (2018) Biomedical applications of silver nanoparticles: An up-to-date overview. Nanomater (Basel, Switzerland) [Internet] 8(9):681. Available from: https://pubmed.ncbi. nlm.nih.gov/30200373

145. Kumar SSD, Rajendran NK, Houreld NN, Abrahamse H (2018) Recent advances on silver nanoparticle and biopolymer-based biomaterials for wound healing applications. Int J Biol Macromol [Internet] 115:165-175. Available from: https://www.sciencedirect. com/science/article/pii/S014181301830518X

146. Gunasekaran T, Nigusse T, Dhanaraju MD (2012) Silver nanoparticles as real topical bullets for wound healing. J Am Coll Clin Wound Spec [Internet] 3(4):82-96. Available from: https:// pubmed.ncbi.nlm.nih.gov/24527370

147. Thirumurugan G, Veni VS, Ramachandran S, Seshagiri Rao JVLN, Dhanaraju MD (2011) Superior wound healing effect of topically delivered silver nanoparticle formulation using ecofriendly potato plant pathogenic fungus: synthesis and characterization [Internet]. J Biomed Nanotechnol Vol 7:p 659-666. Available from: https://www.ingentaconnect.com/content/asp/ jbn/2011/00000007/00000005/art00006

148. Boucher W, Stern JM, Kotsinyan V, Kempuraj D, Papaliodis D, Cohen MS, Theoharides TC (2008) Intravesical nanocrystalline silver decreases experimental bladder inflammation. J Urol [Internet] 179(4):1598-1602. Available from: https://doi.org/10. 1016/j.juro.2007.11.037 
149. Dissemond J, Böttrich JG, Braunwarth H, Hilt J, Wilken P, Münter KC (2017) Evidence for silver in wound care - meta-analysis of clinical studies from 2000-2015. JDDG J der Dtsch Dermatologischen Gesellschaft [Internet] 15(5):524-535. Available from: https:// doi.org/10.1111/ddg.13233

150. Park HJ, Kim JY, Kim J, Lee JH, Hahn JS, Gu MB et al (2009) Silver-ion-mediated reactive oxygen species generation affecting bactericidal activity. Water Res [Internet] 43(4):1027-1032. Available from: https://www.sciencedirect.com/science/article/ pii/S0043135408006039

151. Yang Z, Sharma AK, Marshall M, Kron IL, Laubach VE (2008) NADPH oxidase in bone marrow-derived cells mediates pulmonary ischemia-reperfusion injury. Am J Respir Cell Mol Biol [Internet] 40(3):375-381. Available from: https://pubmed.ncbi. nlm.nih.gov/18787174

152. Carlson C, Hussain SM, Schrand AM, K. Braydich-Stolle L, Hess KL, Jones RL et al (2008) Unique cellular interaction of silver nanoparticles: Size-dependent generation of reactive oxygen species. J Phys Chem B [Internet] 112(43):13608-13619. Available from: https://doi.org/10.1021/jp712087m

153. Pal S, Tak YK, Song JM (2007) Does the antibacterial activity of silver nanoparticles depend on the shape of the nanoparticle? A study of the Gram-negative bacterium Escherichia coli. Appl Environ Microbiol [Internet] 73(6):1712-1720. Available from: https://pubmed.ncbi.nlm.nih.gov/17261510

154. Yamanaka M, Hara K, Kudo J (2005) Bactericidal actions of a silver ion solution on Escherichia coli, studied by energy-filtering transmission electron microscopy and proteomic analysis. Appl Environ Microbiol [Internet] 71(11):7589-7593. Available from: https://pubmed.ncbi.nlm.nih.gov/16269810

155. Jung WK, Koo HC, Kim KW, Shin S, Kim SH, Park YH (2008) Antibacterial activity and mechanism of action of the silver ion in Staphylococcus aureus and Escherichia coli. Appl Environ Microbiol [Internet] 74(7):2171-2178. Available from: https:// pubmed.ncbi.nlm.nih.gov/18245232

156. Castillo PM, Herrera JL, Fernandez-Montesinos R, Caro C, Zaderenko AP, Mejías JA et al (2008) Tiopronin monolayerprotected silver nanoparticles modulate IL-6 secretion mediated by Toll-like receptor ligands. Nanomedicine [Internet] 3(5):627635. Available from: https://doi.org/10.2217/17435889.3.5.627

157. Huang Y, Li X, Liao Z, Zhang G, Liu Q, Tang J et al (2007) A randomized comparative trial between Acticoat and SD-Ag in the treatment of residual burn wounds, including safety analysis. Burns [Internet] 33(2):161-166. Available from: https://www. sciencedirect.com/science/article/pii/S0305417906001860

158. GhavamiNejad A, Rajan Unnithan A, Ramachandra Kurup Sasikala A, Samarikhalaj M, Thomas RG, Jeong YY et al (2015) Mussel-inspired electrospun nanofibers functionalized with size-controlled silver nanoparticles for wound dressing application. ACS Appl Mater Interfaces [Internet] 7(22):12176-12183. Available from: https://doi.org/10. 1021/acsami.5b02542

159. Liu J, Sonshine DA, Shervani S, Hurt RH (2010) Controlled release of biologically active silver from nanosilver surfaces. ACS Nano [Internet] 4(11):6903-6913. Available from: https:// doi.org/10.1021/nn102272n

160. Zhou Y, Chen R, He T, Xu K, Du D, Zhao N et al (2016) Biomedical potential of ultrafine $\mathrm{Ag} / \mathrm{AgCl}$ nanoparticles coated on graphene with special reference to antimicrobial performances and burn wound healing. ACS Appl Mater Interfaces [Internet] 8(24):15067-15075. Available from: https://doi.org/10. 1021/acsami.6b03021

161. El-Aassar MR, Ibrahim OM, Fouda MMG, El-Beheri NG, Agwa MM (2020) Wound healing of nanofiber comprising Polygalacturonic/Hyaluronic acid embedded silver nanoparticles: In-vitro and in-vivo studies. Carbohydr Polym [Internet] 238:116175.
Available from: https://www.sciencedirect.com/science/article/ pii/S0144861720303490

162. Naskar A, Lee S, Kim K (2020) Easy one-pot low-temperature synthesized $\mathrm{Ag}-\mathrm{ZnO}$ nanoparticles and their activity against clinical isolates of methicillin-resistant staphylococcus aureus [Internet]. Front Bioengineer Biotechnol Vol 8:p 216. Available from: https://www.frontiersin.org/article/10.3389/fbioe.2020.00216

163. Niska K, Zielinska E, Radomski MW, Inkielewicz-Stepniak I (2018) Metal nanoparticles in dermatology and cosmetology: Interactions with human skin cells. Chem Biol Interact [Internet] 295:38-51. Available from: https://www.sciencedirect.com/ science/article/pii/S0009279716306299

164. Elahi N, Kamali M, Baghersad MH (2018) Recent biomedical applications of gold nanoparticles: A review. Talanta [Internet] 184:537-556. Available from: https://www.sciencedirect. com/science/article/pii/S0039914018302054

165. Paladini F, Pollini M (2019) Antimicrobial silver nanoparticles for wound healing application: Progress and future trends. Mater (Basel, Switzerland) [Internet] 12(16):2540. Available from: https://www.pubmed.ncbi.nlm.nih.gov/31404974

166. Vijayakumar V, Samal SK, Mohanty S, Nayak SK (2019) Recent advancements in biopolymer and metal nanoparticle-based materials in diabetic wound healing management. Int J Biol Macromol [Internet] 122:137-148. Available from: https://www.sciencedir ect.com/science/article/pii/S0141813018338923

167. Huang Y, Yu F, Park YS, Wang J, Shin MC, Chung HS et al (2010) Co-administration of protein drugs with gold nanoparticles to enable percutaneous delivery. Biomaterials [Internet] 31(34):9086-9091. Available from: https://pubmed.ncbi. nlm.nih.gov/20828812

168. Naraginti S, Kumari PL, Das RK, Sivakumar A, Patil SH, Andhalkar VV (2016) Amelioration of excision wounds by topical application of green synthesized, formulated silver and gold nanoparticles in albino Wistar rats. Mater Sci Eng C [Internet] 62:293-300. Available from: https://www.sciencedirect. com/science/article/pii/S0928493116300686

169. Jayakumar R, Prabaharan M, Sudheesh Kumar PT, Nair S V, Tamura H (2011) Biomaterials based on chitin and chitosan in wound dressing applications. Biotechnol Adv [Internet] 29(3):322-337. Available from: https://www.sciencedir ect.com/science/article/pii/S0734975011000061

170. Hsu S, Chang YB, Tsai CL, Fu KY, Wang SH, Tseng HJ (2011) Characterization and biocompatibility of chitosan nanocomposites. Colloids Surfaces B Biointerfaces [Internet] 85(2):198-206. Available from: https://www.sciencedir ect.com/science/article/pii/S092777651100107X

171. Sherwani MA, Tufail S, Khan AA, Owais M (2015) Gold nanoparticle-photosensitizer conjugate based photodynamic inactivation of biofilm producing cells: Potential for treatment of C. albicans infection in BALB/c Mice. PLoS One [Internet] 10(7):e0131684-e0131684. Available from: https://pubmed. ncbi.nlm.nih.gov/26148012

172. Volkova N, Yukhta M, Pavlovich O, Goltsev A (2016) Application of cryopreserved fibroblast culture with au nanoparticles to treat burns. Nanoscale Res Lett [Internet] 11(1):22. Available from: https://pubmed.ncbi.nlm.nih.gov/26762263

173. Gupta M, Mahajan VK, Mehta KS, Chauhan PS (2014) Zinc therapy in dermatology: a review. Dermatol Res Pract [Internet] 2014:709152. Available from: https://pubmed.ncbi.nlm. nih.gov/25120566

174. Wessels I, Maywald M, Rink L (2017) Zinc as a gatekeeper of immune function. nutrients [Internet] 9(12):1286. Available from: https://pubmed.ncbi.nlm.nih.gov/29186856

175. Jiang J, Pi J, Cai J (2018) The advancing of zinc oxide nanoparticles for biomedical applications. Bioinorg Chem Appl 
[Internet] 2018:1062562. Available from: https://pubmed.ncbi. nlm.nih.gov/30073019

176. Siddiqi KS, Ur Rahman A, Tajuddin, Husen A (2018) Properties of zinc oxide nanoparticles and their activity against microbes. Nanoscale Res Lett [Internet] 13(1):141. Available from: https://pubmed.ncbi.nlm.nih.gov/29740719

177. Mishra PK, Mishra H, Ekielski A, Talegaonkar S, Vaidya B (2017) Zinc oxide nanoparticles: a promising nanomaterial for biomedical applications. Drug Discov Today [Internet] 22(12):1825-1834. Available from: https://www.scien cedirect.com/science/article/pii/S1359644617300776

178. Sudheesh Kumar PT, Lakshmanan V-K, Anilkumar T V, Ramya C, Reshmi P, Unnikrishnan AG et al (2012) Flexible and microporous chitosan hydrogel/nano $\mathrm{ZnO}$ composite bandages for wound dressing: In vitro and in vivo evaluation. ACS Appl Mater Interfaces [Internet] 4(5):2618-2629. Available from: https://doi.org/10.1021/am300292v

179. Balaure PC, Holban AM, Grumezescu AM, Mogoşanu GD, Bălşeanu TA, Stan MS et al (2019) In vitro and in vivo studies of novel fabricated bioactive dressings based on collagen and zinc oxide 3D scaffolds. Int J Pharm [Internet] 557:199-207. Available from: https://www.sciencedirect.com/science/article/ pii/S0378517318309815

180. Gao Y, Han Y, Cui M, Tey HL, Wang L, Xu C (2017) ZnO nanoparticles as an antimicrobial tissue adhesive for skin wound closure. J Mater Chem B [Internet] 5(23):4535-4541. Available from: https://doi.org/10.1039/C7TB00664K

181. Tiwari M, Narayanan K, Thakar MB, Jagani H V, Venkata Rao J (2014) Biosynthesis and wound healing activity of copper nanoparticles. IET Nanobiotechnology [Internet] 8(4):230237. Available from: https://doi.org/10.1049/iet-nbt.2013.0052

182. Borkow G, Gabbay J, Dardik R, Eidelman AI, Lavie Y, Grunfeld Y et al (2010) Molecular mechanisms of enhanced wound healing by copper oxide-impregnated dressings. Wound Repair Regen [Internet] 18(2):266-275. Available from: https://doi.org/10.1111/j.1524-475X.2010.00573.x

183. Gopal A, Kant V, Gopalakrishnan A, Tandan SK, Kumar D (2014) Chitosan-based copper nanocomposite accelerates healing in excision wound model in rats. Eur J Pharmacol [Internet] 731:8-19. Available from: http://europepmc.org/abstract/ MED/24632085

184. Quignard S, Coradin T, Powell JJ, Jugdaohsingh R (2017) Silica nanoparticles as sources of silicic acid favoring wound healing in vitro. Colloids Surfaces B Biointerfaces [Internet] 155:530537. Available from: https://www.sciencedirect.com/science/artic le/pii/S0927776517302357

185. Alvarez GS, Hélary C, Mebert AM, Wang X, Coradin T, Desimone MF (2014) Antibiotic-loaded silica nanoparticlecollagen composite hydrogels with prolonged antimicrobial activity for wound infection prevention. J Mater Chem B [Internet] 2(29):4660-4670. Available from: https://doi.org/10.1039/ C4TB00327F

186. Perumal S, Kumar Ramadass S, Madhan B (2014) Sol-gel processed mupirocin silica microspheres loaded collagen scaffold: a synergistic bio-composite for wound healing. Eur J Pharm Sci [Internet] 52:26-33. Available from: http://europepmc.org/abstract/ MED/24514452

187. Öri F, Dietrich R, Ganz C, Dau M, Wolter D, Kasten A et al (2017) Silicon-dioxide-polyvinylpyrrolidone as a wound dressing for skin defects in a murine model. J Cranio-Maxillofacial Surg [Internet] 45(1):99-107. Available from: https://www.scien cedirect.com/science/article/pii/S1010518216302347

188. Seisenbaeva GA, Fromell K, Vinogradov VV, Terekhov AN, Pakhomov AV, Nilsson B et al (2017) Dispersion of TiO(2) nanoparticles improves burn wound healing and tissue regeneration through specific interaction with blood serum proteins. Sci Rep
[Internet] 7(1):15448. Available from: https://pubmed.ncbi.nlm. nih.gov/29133853

189. Khalid A, Ullah H, Ul-Islam M, Khan R, Khan S, Ahmad F et al (2017) Bacterial cellulose- $\mathrm{TiO} 2$ nanocomposites promote healing and tissue regeneration in burn mice model. RSC Adv [Internet] 7(75):47662-47668. Available from: https://doi.org/ 10.1039/C7RA06699F

190. Peng CC, Yang MH, Chiu WT, Chiu CH, Yang C-S, Chen YW et al (2008) Composite nano-titanium oxide-chitosan artificial skin exhibits strong wound-healing effect-an approach with anti-inflammatory and bactericidal kinetics. Macromol Biosci [Internet] 8(4):316-327. Available from: https://doi.org/10.1002/ mabi.200700188

191. Archana D, Dutta J, Dutta PK (2013) Evaluation of chitosan nano dressing for wound healing: Characterization, in vitro and in vivo studies. Int J Biol Macromol [Internet] 57:193-203. Available from: https://www.sciencedirect.com/science/article/ pii/S0141813013000858

192. Veiseh O, Kievit FM, Fang C, Mu N, Jana S, Leung MC et al (2010) Chlorotoxin bound magnetic nanovector tailored for cancer cell targeting, imaging, and siRNA delivery. Biomaterials [Internet] 31(31):8032-8042. Available from: https://www.scien cedirect.com/science/article/pii/S0142961210008574

193. Wahajuddin, Arora S (2012) Superparamagnetic iron oxide nanoparticles: magnetic nanoplatforms as drug carriers. Int $\mathbf{J}$ Nanomedicine [Internet] 7:3445-3471. Available from: https:// pubmed.ncbi.nlm.nih.gov/22848170

194. Dulińska-Litewka J, Łazarczyk A, Hałubiec P, Szafrański O, Karnas K, Karewicz A (2019) Superparamagnetic iron oxide nanoparticles-current and prospective medical applications. mater (Basel, Switzerland) [Internet] 12(4):617. Available from: https://pubmed.ncbi.nlm.nih.gov/30791358

195. Khashan KS, Sulaiman GM, Mahdi R (2017) Preparation of iron oxide nanoparticles-decorated carbon nanotube using laser ablation in liquid and their antimicrobial activity. Artif Cells, Nanomed Biotechnol [Internet] 45(8):1699-1709. Available from: https://doi.org/10.1080/21691401.2017.1282498

196. Arakha M, Pal S, Samantarrai D, Panigrahi TK, Mallick BC, Pramanik K et al (2015) Antimicrobial activity of iron oxide nanoparticle upon modulation of nanoparticle-bacteria interface. Sci Rep [Internet] 5(1):14813. Available from: https:// doi.org/10.1038/srep14813

197. Ziv-Polat O, Topaz M, Brosh T, Margel S (2010) Enhancement of incisional wound healing by thrombin conjugated iron oxide nanoparticles. Biomaterials [Internet] 31(4):741-747. Available from: https://www.sciencedirect.com/science/article/pii/ S0142961209010618

198. Yaqoob AA, Ahmad H, Parveen T, Ahmad A, Oves M, Ismail IMI et al (2020) Recent advances in metal decorated nanomaterials and their various biological applications: A review [Internet]. Front Chem Vol 8:p 341. Available from: https:// www.frontiersin.org/article/10.3389/fchem.2020.00341

199. C Thomas S, Kumar Mishra P, Talegaonkar S (2015) Ceramic nanoparticles: Fabrication methods and applications in drug delivery [Internet]. Curr Pharmaceut Design Vol 21: p 6165-6188. Available from: http://www.eurekaselect.com/node/136144/article

200. Kamaly N, Xiao Z, Valencia PM, Radovic-Moreno AF, Farokhzad OC (2012) Targeted polymeric therapeutic nanoparticles: design, development and clinical translation. Chem Soc Rev [Internet] 41(7):2971-3010. Available from: https:// pubmed.ncbi.nlm.nih.gov/22388185

201. De Jong WH, Borm PJA (2008) Drug delivery and nanoparticles:applications and hazards. Int J Nanomedicine [Internet] 3(2):133-149. Available from: https://pubmed.ncbi. nlm.nih.gov/18686775 
202. Blanco E, Hsiao A, Mann AP, Landry MG, Meric-Bernstam F, Ferrari M (2011) Nanomedicine in cancer therapy: Innovative trends and prospects. Cancer Sci [Internet] 102(7):1247-1252. Available from: https://doi.org/10.1111/j.1349-7006.2011.01941.x

203. Sigmund W, Yuh J, Park H, Maneeratana V, Pyrgiotakis G, Daga A et al (2006) Processing and structure relationships in electrospinning of ceramic fiber systems. J Am Ceram Soc [Internet] 89(2):395-407. Available from: https://doi.org/10. 1111/j.1551-2916.2005.00807.x

204. Covarrubias C, Cádiz M, Maureira M, Celhay I, Cuadra F, von Marttens A (2018) Bionanocomposite scaffolds based on chitosan-gelatin and nanodimensional bioactive glass particles: In vitro properties and in vivo bone regeneration. J Biomater Appl [Internet] 32(9):1155-1163. Available from: https://doi. org/10.1177/0885328218759042

205. Li Y, Guo Y, Niu W, Chen M, Xue Y, Ge J et al (2018) Biodegradable Multifunctional Bioactive Glass-Based Nanocomposite Elastomers with Controlled Biomineralization Activity, Real-Time Bioimaging Tracking, and Decreased Inflammatory Response. ACS Appl Mater Interfaces [Internet] 10(21):17722-17731. Available from: https://doi.org/10. 1021/acsami.8b04856

206. Vichery C, Nedelec JM (2016) Bioactive glass nanoparticles: From synthesis to materials design for biomedical applications. Mater (Basel, Switzerland) [Internet] 9(4):288. Available from: https://pubmed.ncbi.nlm.nih.gov/28773412

207. Wu C, Zhou Y, Fan W, Han P, Chang J, Yuen J et al (2012) Hypoxia-mimicking mesoporous bioactive glass scaffolds with controllable cobalt ion release for bone tissue engineering. Biomaterials [Internet] 33(7):2076-2085. Available from: https:// www.sciencedirect.com/science/article/pii/S0142961211013962

208. Zhang K, Chai B, Ji H, Chen liuqing, Ma Y, Zhu L et al (2021) Bioglass promotes wound healing by inhibiting endothelial cell pyroptosis through regulation of the connexin 43/reactive oxygen species (ROS) signaling pathway. Lab Investig [Internet] Available from: https://doi.org/10.1038/s41374-021-00675-6

209. Huang YF, Wang YF, Yan XP (2010) Amine-functionalized magnetic nanoparticles for rapid capture and removal of bacterial pathogens. Environ Sci Technol [Internet] 44(20):7908-7913. Available from: https://doi.org/10.1021/es102285n

210. Mashaghi S, Jadidi T, Koenderink G, Mashaghi A (2013) Lipid nanotechnology. Int J Mol Sci [Internet] 14(2):4242-4282. Available from: https://pubmed.ncbi.nlm.nih.gov/23429269

211. Safinya CR, Ewert KK (2012) Materials chemistry: Liposomes derived from molecular vases. Nature [Internet] 489(7416):372-374. Available from: http://europepmc. org/abstract/MED/22996547

212. Monteforte AJ, Lam B, Das S, Mukhopadhyay S, Wright CS, Martin PE et al (2016) Glypican-1 nanoliposomes for potentiating growth factor activity in therapeutic angiogenesis. Biomaterials [Internet] 94:45-56. Available from: https://pubmed.ncbi. nlm.nih.gov/27101205

213. Tu C, Das S, Baker AB, Zoldan J, Suggs LJ (2015) Nanoscale strategies: treatment for peripheral vascular disease and critical limb ischemia. ACS Nano [Internet] 9(4):3436-3452. Available from: https://pubmed.ncbi.nlm.nih.gov/25844518

214. Naseri N, Valizadeh H, Zakeri-Milani P (2015) Solid lipid nanoparticles and nanostructured lipid carriers: Structure, preparation and application. Adv Pharm Bull [Internet] 5(3):305-313. Available from: https://pubmed.ncbi.nlm.nih.gov/26504751

215. Arantes VT, Faraco AAG, Ferreira FB, Oliveira CA, MartinsSantos E, Cassini-Vieira P et al (2020) Retinoic acid-loaded solid lipid nanoparticles surrounded by chitosan film support diabetic wound healing in in vivo study. Colloids Surfaces B Biointerfaces [Internet] 188:110749. Available from: https://www.sciencedirect. com/science/article/pii/S0927776519308938
216. Küchler S, Wolf NB, Heilmann S, Weindl G, Helfmann J, Yahya MM et al (2010) 3D-Wound healing model: Influence of morphine and solid lipid nanoparticles. J Biotechnol [Internet] 148(1):24-30. Available from: https://www.sciencedirect. com/science/article/pii/S0168165610000283

217. Duan Y, Dhar A, Patel C, Khimani M, Neogi S, Sharma P et al (2020) A brief review on solid lipid nanoparticles: part and parcel of contemporary drug delivery systems. RSC Adv [Internet] 10(45):26777-26791. Available from: https://doi.org/10. 1039/D0RA03491F

218. Huang S, Fu X (2010) Naturally derived materials-based cell and drug delivery systems in skin regeneration. J Control Release [Internet] 142(2):149-159. Available from: https://www.scien cedirect.com/science/article/pii/S0168365909007135

219. Ye M, Kim S, Park K (2010) Issues in long-term protein delivery using biodegradable microparticles. J Control Release [Internet] 146(2):241-260. Available from: https://www.sciencedirect. com/science/article/pii/S0168365910003603

220. Gainza G, Aguirre JJ, Pedraz JL, Hernández RM, Igartua M (2013) rhEGF-loaded PLGA-Alginate microspheres enhance the healing of full-thickness excisional wounds in diabetised Wistar rats. Eur J Pharm Sci [Internet] 50(3):243-252. Available from: https://www.sciencedirect.com/science/article/pii/ S0928098713002571

221. Yun YH, Goetz DJ, Yellen P, Chen W (2004) Hyaluronan microspheres for sustained gene delivery and site-specific targeting. Biomaterials [Internet] 25(1):147-157. Available from: https:// www.sciencedirect.com/science/article/pii/S0142961203004678

222. Chu Y, Yu D, Wang P, Xu J, Li D, Ding M (2010) Nanotechnology promotes the full-thickness diabetic wound healing effect of recombinant human epidermal growth factor in diabetic rats. Wound Repair Regen [Internet]. 18(5):499-505. Available from: https://doi.org/10.1111/j.1524-475X.2010.00612.x

223. Murphy G, Nagase H (2008) Progress in matrix metalloproteinase research. Mol Aspects Med [Internet] 29(5):290-308. Available from: https://pubmed.ncbi.nlm.nih.gov/18619669

224. Chereddy KK, Her C-H, Comune M, Moia C, Lopes A, Porporato PE et al (2014) PLGA nanoparticles loaded with host defense peptide LL37 promote wound healing. J Control Release [Internet] 194:138-147. Available from: https://www.sciencedirect. com/science/article/pii/S0168365914005987

225. Dave V, Kushwaha K, Yadav RB, Agrawal U (2017) Hybrid nanoparticles for the topical delivery of norfloxacin for the effective treatment of bacterial infection produced after burn. J Microencapsul [Internet] 34(4):351-365. Available from: https://doi.org/ 10.1080/02652048.2017.1337249

226. Young S, Wong M, Tabata Y, Mikos AG (2005) Gelatin as a delivery vehicle for the controlled release of bioactive molecules. J Control Release [Internet] 109(1):256-274. Available from: https://www.sciencedirect.com/science/article/pii/ S0168365905004979

227. Han K, Lee KD, Gao ZG, Park JS. Preparation and evaluation of poly(l-lactic acid) microspheres containing rhEGF for chronic gastric ulcer healing. J Control Release [Internet] 75(3):259-269. Available from: https://www.sciencedirect.com/science/article/ pii/S016836590100400X

228. Zavan B, Vindigni V, Vezzù K, Zorzato G, Luni C, Abatangelo $\mathrm{G}$ et al (2009) Hyaluronan based porous nano-particles enriched with growth factors for the treatment of ulcers: a placebo-controlled study. J Mater Sci Mater Med [Internet] 20(1):235-247. Available from: https://doi.org/10.1007/s10856-008-3566-3

229. Medel S, Syrova Z, Kovacik L, Hrdy J, Hornacek M, Jager E et al (2017) Curcumin-bortezomib loaded polymeric nanoparticles for synergistic cancer therapy. Eur Polym J [Internet] 93:116-131. Available from: https://www.sciencedirect.com/science/article/ pii/S0014305717306985 
230. Medina DX, Chung EP, Bowser R, Sirianni RW (2019) Lipid and polymer blended polyester nanoparticles loaded with adapalene for activation of retinoid signaling in the CNS following intravenous administration. J Drug Deliv Sci Technol [Internet] 52:927-933. Available from: https://www.sciencedirect.com/science/article/pii/ S1773224719300358

231. Kell AJ, Stewart G, Ryan S, Peytavi R, Boissinot M, Huletsky A et al (2008) Vancomycin-modified nanoparticles for efficient targeting and preconcentration of gram-positive and gram-negative bacteria. ACS Nano [Internet] 2(9):1777-1788. Available from: https://doi.org/10.1021/nn700183g

232. Turos E, Shim JY, Wang Y, Greenhalgh K, Reddy GSK, Dickey $S$ et al (2006) Antibiotic-conjugated polyacrylate nanoparticles: new opportunities for development of anti-MRSA agents. Bioorg Med Chem Lett [Internet] 17(1):53-56. Available from: https:// pubmed.ncbi.nlm.nih.gov/17049850

233. Garay-Jimenez JC, Gergeres D, Young A, Lim D V, Turos E (2009) Physical properties and biological activity of poly(butyl acrylatestyrene) nanoparticle emulsions prepared with conventional and polymerizable surfactants. Nanomedicine [Internet] 5(4):443-451. Available from: https://pubmed.ncbi.nlm.nih.gov/19523413

234. Lin YH, Lin JH, Li TS, Wang SH, Yao CH, Chung WY et al (2016) Dressing with epigallocatechin gallate nanoparticles for wound regeneration. Wound Repair Regen [Internet] 24(2):287301. Available from: https://doi.org/10.1111/wrr.12372

235. Sun Y, Bhattacharjee A, Reynolds M, Li YV (2021) Synthesis and characterizations of gentamicin-loaded poly-lactic-co-glycolic (PLGA) nanoparticles. J Nanoparticle Res [Internet] 23(8):155. Available from: https://doi.org/10.1007/s11051-021-05293-3

236. Stallmeyer B, Kämpfer H, Kolb N, Pfeilschifter J, Frank S (1999) The Function of Nitric Oxide in Wound Repair: Inhibition of Inducible Nitric Oxide-Synthase Severely Impairs Wound Reepithelialization. J Invest Dermatol [Internet] 113(6):1090-1098. Available from: https://www.sciencedirect.com/science/article/ pii/S0022202X15407031

237. Weller RB (2009) Nitric oxide-containing nanoparticles as an antimicrobial agent and enhancer of wound healing. J Invest Dermatol [Internet] 129(10):2335-2337. Available from: https:// www.sciencedirect.com/science/article/pii/S0022202X15340914

238. Schwentker A, Vodovotz Y, Weller R, Billiar TR (2002) Nitric oxide and wound repair: role of cytokines?. Nitric Oxide [Internet] 7(1):1-10. Available from: https://www.sciencedirect.com/ science/article/pii/S1089860302000022

239. Schapiro JM, Libby SJ, Fang FC (2003) Inhibition of bacterial DNA replication by zinc mobilization during nitrosative stress. Proc Natl Acad Sci U S A [Internet] 100(14):8496-8501. Available from: https://pubmed.ncbi.nlm.nih.gov/12829799

240. Stevanin TM, Ioannidis N, Mills CE, Kim SO, Hughes MN, Poole RK (2000) Flavohemoglobin hmp affords inducible protection for escherichia coli respiration, Catalyzed by cytochromesbo or bd, from Nitric Oxide*. J Biol Chem [Internet] 275(46):3586835875. Available from: https://www.sciencedirect.com/science/ article/pii/S0021925820886840

241. Engelsman AF, Krom BP, Busscher HJ, van Dam GM, Ploeg RJ, van der Mei HC (2009) Antimicrobial effects of an NOreleasing poly(ethylene vinylacetate) coating on soft-tissue implants in vitro and in a murine model. Acta Biomater [Internet] 5(6):1905-1910. Available from: https://www.sciencedirect. com/science/article/pii/S1742706109000452

242. Nablo BJ, Prichard HL, Butler RD, Klitzman B, Schoenfisch MH (2005) Inhibition of implant-associated infections via nitric oxide release. Biomaterials [Internet] 26(34):6984-6990. Available from: https://www.sciencedirect.com/science/article/pii/ S0142961205004011

243. DeRosa F, Kibbe MR, Najjar SF, Citro ML, Keefer LK, Hrabie JA (2007) Nitric oxide-releasing fabrics and other acrylonitrile-based diazeniumdiolates. J Am Chem Soc [Internet] 129(13):37863787. Available from: https://doi.org/10.1021/ja0686864

244. Nablo BJ, Chen TY, Schoenfisch MH (2001) Sol-gel derived nitric-oxide releasing materials that reduce bacterial adhesion. J Am Chem Soc [Internet] 123(39):9712-9713. Available from: https://doi.org/10.1021/ja0165077

245. Storm WL, Schoenfisch MH (2013) Nitric oxide-releasing xerogels synthesized from n-diazeniumdiolate-modified silane precursors. ACS Appl Mater Interfaces [Internet] 5(11):4904-4912. Available from: https://doi.org/10.1021/am4006397

246. Hetrick EM, Shin JH, Paul HS, Schoenfisch MH (2009) Antibiofilm efficacy of nitric oxide-releasing silica nanoparticles. Biomaterials [Internet] 30(14):2782-2789. Available from: https://pubmed.ncbi.nlm.nih.gov/19233464

247. Han G, Nguyen LN, Macherla C, Chi Y, Friedman JM, Nosanchuk JD et al (2012) Nitric oxide-releasing nanoparticles accelerate wound healing by promoting fibroblast migration and collagen deposition. Am J Pathol [Internet] 180(4):1465-1473. Available from: https:// www.sciencedirect.com/science/article/pii/S0002944012000156

248. Blecher K, Martinez LR, Tuckman-Vernon C, Nacharaju P, Schairer D, Chouake J et al (2012) Nitric oxide-releasing nanoparticles accelerate wound healing in NOD-SCID mice. Nanomedicine Nanotechnology, Biol Med [Internet] 8(8):1364-1371. Available from: https://www.sciencedirect.com/science/article/ pii/S1549963412000901

249. Gusarov I, Shatalin K, Starodubtseva M, Nudler E (2009) Endogenous nitric oxide protects bacteria against a wide spectrum of antibiotics. Science [Internet] 325(5946):1380-1384. Available from: https://pubmed.ncbi.nlm.nih.gov/19745150

250. Mihu MR, Sandkovsky U, Han G, Friedman JM, Nosanchuk JD, Martinez LR (2010) The use of nitric oxide releasing nanoparticles as a treatment against Acinetobacter baumannii in wound infections. Virulence [Internet] 1(2):62-67. Available from: https://doi.org/10.4161/viru.1.2.10038

251. Makarov VV, Love AJ, Sinitsyna O V, Makarova SS, Yaminsky IV, Taliansky ME et al (2014) Green nanotechnologies: synthesis of metal nanoparticles using plants. Acta Naturae [Internet] 6(1):35-44. Available from: https://pubmed.ncbi.nlm.nih. gov/24772325

252. Kuppusamy P, Yusoff MM, Maniam GP, Govindan N (2014) Biosynthesis of metallic nanoparticles using plant derivatives and their new avenues in pharmacological applications - An updated report. Saudi Pharm J SPJ Off Publ Saudi Pharm Soc [Internet] 24(4):473-484. Available from: https://pubmed.ncbi. nlm.nih.gov/27330378

253. Lakkim V, Reddy MC, Pallavali RR, Reddy KR, Reddy CV, Inamuddin et al (2020) Green synthesis of silver nanoparticles and evaluation of their antibacterial activity against multidrug-resistant bacteria and wound healing efficacy using a murine model. Antibiot (Basel, Switzerland) [Internet] 9(12):902. Available from: https:// pubmed.ncbi.nlm.nih.gov/33322213

254. Wen L, Zeng P, Zhang L, Huang W, Wang H, Chen G (2016) Symbiosis theory-directed green synthesis of silver nanoparticles and their application in infected wound healing. Int J Nanomedicine [Internet] 11:2757-2767. Available from: https://pubmed. ncbi.nlm.nih.gov/27358563

255. Liu Y, Chen W, Kim HI (2012) Antibacterial activity of pHsensitive genipin cross-linked chitosan/poly(ethylene glycol)/silver nanocomposites. Polym Adv Technol [Internet] 23(1):8-14. Available from: https://doi.org/10.1002/pat.1818

256. Barua S, Chattopadhyay P, Aidew L, Buragohain AK, Karak N (2015) Infection-resistant hyperbranched epoxy nanocomposite as a scaffold for skin tissue regeneration. Polym Int [Internet] 64(2):303311. Available from: https://doi.org/10.1002/pi.4790

257. Sivaranjani V, Philominathan P (2016) Synthesize of titanium dioxide nanoparticles using Moringa oleifera leaves 
and evaluation of wound healing activity. Wound Med [Internet] 12:1-5. Available from: https://www.sciencedirect.com/ science/article/pii/S2213909515300057

258. Sankar R, Baskaran A, Shivashangari KS, Ravikumar V (2015) Inhibition of pathogenic bacterial growth on excision wound by green synthesized copper oxide nanoparticles leads to accelerated wound healing activity in Wistar Albino rats. J Mater Sci Mater Med [Internet] 26(7):214. Available from: https://doi.org/ 10.1007/s10856-015-5543-y

259. Sandri G, Bonferoni MC, D’Autilia F, Rossi S, Ferrari F, Grisoli $P$ et al Wound dressings based on silver sulfadiazine solid lipid nanoparticles for tissue repairing. Eur J Pharm Biopharm [Internet] 84(1):84-90. Available from: https://www.sciencedirect.com/ science/article/pii/S0939641112003888

260. Gokce EH, Korkmaz E, Dellera E, Sandri G, Bonferoni MC, Ozer O (2012) Resveratrol-loaded solid lipid nanoparticles versus nanostructured lipid carriers: evaluation of antioxidant potential for dermal applications. Int J Nanomedicine [Internet] 7:1841-1850. Available from: https://pubmed.ncbi.nlm.nih. gov/22605933

261. Küchler S, Radowski MR, Blaschke T, Dathe M, Plendl J, Haag $R$ et al (2009) Nanoparticles for skin penetration enhancement - A comparison of a dendritic core-multishell-nanotransporter and solid lipid nanoparticles. Eur J Pharm Biopharm [Internet] 71(2):243-250. Available from: https://www.sciencedirect. com/science/article/pii/S0939641108003226

262. Akhmetova A, Heinz A (2020) Electrospinning Proteins for Wound Healing Purposes: Opportunities and Challenges. Pharmaceutics [Internet] 13(1):4. Available from: https://pubmed. ncbi.nlm.nih.gov/33374930

263. Chen S, Liu B, Carlson MA, Gombart AF, Reilly DA, Xie J (2017) Recent advances in electrospun nanofibers for wound healing. Nanomedicine (Lond) [Internet] 12(11):1335-1352. Available from: http://europepmc.org/abstract/MED/28520509

264. Ma K, Chan CK, Liao S, Hwang WYK, Feng Q, Ramakrishna S (2008) Electrospun nanofiber scaffolds for rapid and rich capture of bone marrow-derived hematopoietic stem cells. Biomaterials [Internet] 29(13):2096-2103. Available from: https://www.scien cedirect.com/science/article/pii/S0142961208000318

265. Gümüşderelioğlu M, Dalkıranoğlu S, Aydın RST, Çakmak S (2011) A novel dermal substitute based on biofunctionalized electrospun PCL nanofibrous matrix. J Biomed Mater Res Part A [Internet] 98A(3):461-472. Available from: https://doi.org/10. 1002/jbm.a.33143

266. Katti DS, Robinson KW, Ko FK, Laurencin CT (2004) Bioresorbable nanofiber-based systems for wound healing and drug delivery: Optimization of fabrication parameters. J Biomed Mater Res Part B Appl Biomater [Internet] 70B(2):286-296. Available from: https://doi.org/10.1002/jbm.b.30041

267. Keirouz A, Chung M, Kwon J, Fortunato G, Radacsi N (2020) 2D and 3D electrospinning technologies for the fabrication of nanofibrous scaffolds for skin tissue engineering: A review. WIREs Nanomed Nanobiotechnol [Internet] 12(4):e1626 Available from: https://doi.org/10.1002/wnan.1626

268. Veleirinho B, Berti FV, Dias PF, Maraschin M, Ribeiro-do-Valle RM, Lopes-da-Silva JA (2013) Manipulation of chemical composition and architecture of non-biodegradable poly(ethylene terephthalate)/ chitosan fibrous scaffolds and their effects on L929 cell behavior. Mater Sci Eng C [Internet] 33(1):37-46. Available from: https:// www.sciencedirect.com/science/article/pii/S0928493112003657

269. Passalacqua TG, Dutra LA, de Almeida L, Velásquez AMA, Torres FAE, Yamasaki PR et al (2015) Synthesis and evaluation of novel prenylated chalcone derivatives as anti-leishmanial and anti-trypanosomal compounds. Bioorg Med Chem Lett [Internet] 25(16):33423345. Available from: https://www.sciencedirect.com/science/article/ pii/S0960894X15005466
270. Rho KS, Jeong L, Lee G, Seo BM, Park YJ, Hong SD et al Electrospinning of collagen nanofibers: Effects on the behavior of normal human keratinocytes and early-stage wound healing. Biomaterials [Internet] 27(8):1452-1461. Available from: https:// www.sciencedirect.com/science/article/pii/S0142961205007921

271. Hodgkinson T, Yuan XF, Bayat A (2014) Electrospun silk fibroin fiber diameter influences in vitro dermal fibroblast behavior and promotes healing of ex vivo wound models. J Tissue Eng [Internet] 5:2041731414551661-2041731414551661. Available from: https://pubmed.ncbi.nlm.nih.gov/25383171

272. Huang C, Fu X, Liu J, Qi Y, Li S, Wang H (2011) The involvement of integrin $\beta 1$ signaling in the migration and myofibroblastic differentiation of skin fibroblasts on anisotropic collagen-containing nanofibers. Biomaterials [Internet] 33(6):1791-1800. Available from: https://pubmed. ncbi.nlm.nih.gov/22136719

273. Bacakova M, Musilkova J, Riedel T, Stranska D, Brynda E, Zaloudkova $\mathrm{M}$ et al (2016) The potential applications of fibrincoated electrospun polylactide nanofibers in skin tissue engineering. Int J Nanomedicine [Internet] 11:771-789. Available from: https://pubmed.ncbi.nlm.nih.gov/26955273

274. Gupta A, Kumar R, Upadhyay NK, Surekha P, Roy PK (2009) Synthesis, characterization and efficacy of chemically crosslinked PVA hydrogels for dermal wound healing in experimental animals. J Appl Polym Sci [Internet] 111(3):1400-1408. Available from: https://doi.org/10.1002/app.28990

275. Moura LIF, Dias AMA, Carvalho E, de Sousa HC (2013) Recent advances on the development of wound dressings for diabetic foot ulcer treatment-A review. Acta Biomater [Internet] 9(7):7093-7114. Available from: https://www.sciencedirect. com/science/article/pii/S1742706113001633

276. Koski A, Yim K, Shivkumar S (2004) Effect of molecular weight on fibrous PVA produced by electrospinning. Mater Lett [Internet] 58(3):493-497. Available from: https://www.sciencedirect. com/science/article/pii/S0167577X03005329

277. Dash TK, Konkimalla VB (2012) Poly-€-caprolactone based formulations for drug delivery and tissue engineering: A review. $\mathrm{J}$ Control Release [Internet] 158(1):15-33. Available from: https:// www.sciencedirect.com/science/article/pii/S0168365911008492

278. Lin T, Fang J, Wang H, Cheng T, Wang X (2006) Using chitosan as a thickener for electrospinning dilute PVA solutions to improve fibre uniformity. Nanotechnology [Internet]. 17(15):3718-3723. Available from: https://doi.org/10.1088/0957-4484/17/15/017

279. Wang M, Roy AK, Webster TJ (2017) Development of chitosan/ poly(Vinyl Alcohol) electrospun nanofibers for infection related wound healing. Front Physiol [Internet] 7:683. Available from: https://pubmed.ncbi.nlm.nih.gov/28123370

280. Venugopal JR, Zhang Y, Ramakrishna S (2006) In vitro culture of human dermal fibroblasts on electrospun polycaprolactone collagen nanofibrous membrane. Artif Organs [Internet] 30(6):440-446. Available from: https://doi.org/10.1111/j.1525-1594.2006.00239.x

281. Cheng W, Xu R, Li D, Bortolini C, He J, Dong M et al (2016) Artificial extracellular matrix delivers TGFb1 regulating myofibroblast differentiation. RSC Adv [Internet] 6(26):21922-21928. Available from: https://doi.org/10.1039/C5RA26164C

282. Savkovic V, Flämig F, Schneider M, Sülflow K, Loth T, Lohrenz A et al (2016) Polycaprolactone fiber meshes provide a 3D environment suitable for cultivation and differentiation of melanocytes from the outer root sheath of hair follicle. J Biomed Mater Res Part A [Internet] 104(1):26-36. Available from: https://doi. org/10.1002/jbm.a.35536

283. Yari A, Teimourian S, Amidi F, Bakhtiyari M, Heidari F, Sajedi $\mathrm{N}$ et al (2016) The role of biodegradable engineered random polycaprolactone nanofiber scaffolds seeded with nestin-positive hair follicle stem cells for tissue engineering. Adv Biomed Res 
[Internet] 5:22. Available from: https://pubmed.ncbi.nlm.nih.gov/ 26962524

284. Lorden ER, Miller KJ, Ibrahim MM, Bashirov L, Hammett E, Chakraborty S et al (2016) Biostable electrospun microfibrous scaffolds mitigate hypertrophic scar contraction in an immunecompetent murine model. Acta Biomater [Internet] 32:100-109. Available from: https://www.sciencedirect.com/science/article/ pii/S1742706115302634

285. Lorden ER, Miller KJ, Bashirov L, Ibrahim MM, Hammett E, Jung Y et al (2015) Mitigation of hypertrophic scar contraction via an elastomeric biodegradable scaffold. Biomaterials [Internet] 43:61-70. Available from: https://www.sciencedirect.com/ science/article/pii/S0142961214012472

286. Coelho DS, Veleirinho B, Alberti T, Maestri A, Yunes R, Fernando Dias P et al (2020) Electrospinning technology: Designing nanofibers toward wound healing application. Nanomater - Toxicity, Hum Heal Environ

287. Ghasemi-Mobarakeh L, Prabhakaran MP, Morshed M, NasrEsfahani MH, Ramakrishna S (2008) Electrospun poly( $\varepsilon$ caprolactone)/gelatin nanofibrous scaffolds for nerve tissue engineering. Biomaterials [Internet] 29(34):4532-4539. Available from: https://www.sciencedirect.com/science/article/pii/ S0142961208005681

288. Zeugolis DI, Li B, Lareu RR, Chan CK, Raghunath M (2008) Collagen solubility testing, a quality assurance step for reproducible electro-spun nano-fibre fabrication. A technical note. J Biomater Sci Polym Ed [Internet] 19(10):1307-1317. Available from: https://doi.org/10.1163/156856208786052344

289. Law JX, Liau LL, Saim A, Yang Y, Idrus R (2017) Electrospun collagen nanofibers and their applications in skin tissue engineering. Tissue Eng Regen Med [Internet] 14(6):699-718. Available from: https://pubmed.ncbi.nlm.nih.gov/30603521

290. Kaplan D, Adams WW, Farmer B, Viney C (1993) Silk: biology, structure, properties, and genetics. In: silk polymers [Internet]. Am Chemi Soc p 1-2. (ACS Symposium Series; vol. 544). Available from: https://doi.org/10.1021/bk-19940544.ch001

291. Ribeiro TG, Franca JR, Fuscaldi LL, Santos ML, Duarte MC, Lage PS et al (2014) An optimized nanoparticle delivery system based on chitosan and chondroitin sulfate molecules reduces the toxicity of amphotericin $\mathrm{B}$ and is effective in treating tegumentary leishmaniasis. Int $\mathrm{J}$ Nanomedicine [Internet] 9:5341-5353. Available from: https://pubmed.ncbi. nlm.nih.gov/25429219

292. Hao Y, Zhao W, Zhang L, Zeng X, Sun Z, Zhang D et al (2020) Bio-multifunctional alginate/chitosan/fucoidan sponges with enhanced angiogenesis and hair follicle regeneration for promoting full-thickness wound healing. Mater Des [Internet] 193:108863. Available from: https://www.sciencedirect. com/science/article/pii/S026412752030397X

293. Rashtchian M, Hivechi A, Bahrami SH, Milan PB, Simorgh S (2020) Fabricating alginate/poly(caprolactone) nanofibers with enhanced bio-mechanical properties via cellulose nanocrystal incorporation. Carbohydr Polym [Internet] 233:115873. Available from: http://europepmc.org/abstract/MED/32059913

294. Summa M, Russo D, Penna I, Margaroli N, Bayer IS, Bandiera $\mathrm{T}$ et al (2018) A biocompatible sodium alginate/povidone iodine film enhances wound healing. Eur J Pharm Biopharm [Internet] 122:17-24. Available from: https://www.sciencedirect.com/ science/article/pii/S0939641117307750

295. Varaprasad K, Raghavendra GM, Jayaramudu T, Seo J (2016) Nano zinc oxide-sodium alginate antibacterial cellulose fibres. Carbohydr Polym [Internet] 135:349-355. Available from: https://www. sciencedirect.com/science/article/pii/S0144861715008267

296. Shalumon KT, Anulekha KH, Nair S V, Nair S V, Chennazhi KP, Jayakumar R (2011) Sodium alginate/poly(vinyl alcohol)/nano ZnO composite nanofibers for antibacterial wound dressings. Int J Biol Macromol [Internet] 49(3):247-254. Available from: https://www. sciencedirect.com/science/article/pii/S0141813011001309

297. Tang Y, Lan X, Liang C, Zhong Z, Xie R, Zhou Y et al (2019) Honey loaded alginate/PVA nanofibrous membrane as potential bioactive wound dressing. Carbohydr Polym [Internet] 219:113120. Available from: https://www.sciencedirect.com/science/ article/pii/S0144861719305016

298. Shao P, Feng J, Sun P, Xiang N, Lu B, Qiu D (2020) Recent advances in improving stability of food emulsion by plant polysaccharides. Food Res Int [Internet] 137:109376. Available from: http://europepmc.org/abstract/MED/33233078

299. Adeli H, Khorasani MT, Parvazinia M (2019) Wound dressing based on electrospun PVA/chitosan/starch nanofibrous mats: Fabrication, antibacterial and cytocompatibility evaluation and in vitro healing assay. Int J Biol Macromol [Internet] 122:238254. Available from: https://www.sciencedirect.com/science/ article/pii/S0141813018337644

300. Wang H, Ziegler GR (2019) Electrospun nanofiber mats from aqueous starch-pullulan dispersions: Optimizing dispersion properties for electrospinning. Int J Biol Macromol [Internet] 133:1168-1174. Available from: https://www.sciencedirect. com/science/article/pii/S0141813019309274

301. Movahedi M, Asefnejad A, Rafienia M, Khorasani MT (2020) Potential of novel electrospun core-shell structured polyurethane/ starch (hyaluronic acid) nanofibers for skin tissue engineering: In vitro and in vivo evaluation. Int J Biol Macromol [Internet] 146:627-637. Available from: https://www.sciencedirect. com/science/article/pii/S0141813019368886

302. Khan MQ, Kharaghani D, Sanaullah, Shahzad A, Saito Y, Yamamoto T et al (2019) Fabrication of antibacterial electrospun cellulose acetate/ silver-sulfadiazine nanofibers composites for wound dressings applications. Polym Test [Internet] 74:39-44. Available from: https://www.sciencedirect.com/ science/article/pii/S0142941818316945

303. Nada AA, Ali EA, Soliman AAF, Shen J, Abou-Zeid NY, Hudson SM (2020) Multi-layer dressing made of laminated electrospun nanowebs and cellulose-based adhesive for comprehensive wound care. Int J Biol Macromol [Internet] 162:629-644. Available from: http://europepmc.org/abstract/MED/32574744

304. Yazdanbakhsh MF, Rashidi A, Rahimi MK, Khajavi R, Shafaroodi H (2018) The effect of impregnated alpha-cellulose nanofibers with ciprofloxacin hydrochloride on staphylococcus aureus in vitro and healing process of wound in Rat. Regen Eng Transl Med [Internet]. 4(4):247-256. Available from: https://doi.org/10.1007/ s40883-018-0066-y

305. Li H, Zhang Z, Godakanda VU, Chiu YJ, Angkawinitwong U, Patel K et al (2019) The effect of collection substrate on electrospun ciprofloxacin-loaded poly(vinylpyrrolidone) and ethyl cellulose nanofibers as potential wound dressing materials. Mater Sci Eng C [Internet] 104:109917. Available from: https://www. sciencedirect.com/science/article/pii/S0928493119306265

306. Zaitseva O, Khudyakov A, Sergushkina M, Solomina O, Polezhaeva T (2020) Pectins as a universal medicine. Fitoterapia [Internet] 146:104676. Available from: http://europepmc.org/ abstract/MED/32561422

307. Chen S, Cui S, Hu J, Zhou Y, Liu Y (2017) Pectinate nanofiber mat with high absorbency and antibacterial activity: A potential superior wound dressing to alginate and chitosan nanofiber mats. Carbohydr Polym [Internet] 174:591-600. Available from: https:// www.sciencedirect.com/science/article/pii/S0144861717307336

308. Augustine R, Augustine A, Kalarikkal N, Thomas S (2016) Fabrication and characterization of biosilver nanoparticles loaded calcium pectinate nano-micro dual-porous antibacterial wound dressings. Prog Biomater [Internet] 5(3):223-235. Available from: https://doi.org/10.1007/s40204-016-0060-8 
309. Taheri A, Jafari SM (2019) Gum-based nanocarriers for the protection and delivery of food bioactive compounds. Adv Colloid Interface Sci [Internet] 269:277-295. Available from: http:// europepmc.org/abstract/MED/31132673

310. Mohammadi MR, Kargozar S, Bahrami SH, Rabbani S (2020) An excellent nanofibrous matrix based on gum tragacanth-poly ( $\varepsilon$-caprolactone)-poly (vinyl alcohol) for application in diabetic wound healing. Polym Degrad Stab v 174

311. Rad ZP, Mokhtari J, Abbasi M (2018) Fabrication and characterization of $\mathrm{PCL} / \mathrm{zein} / \mathrm{gum}$ arabic electrospun nanocomposite scaffold for skin tissue engineering. Mater Sci Eng C [Internet] 93:356-366. Available from: https://www. sciencedirect.com/science/article/pii/S0928493118300845

312. Hoseyni SZ, Jafari SM, Tabarestani HS, Ghorbani M, Assadpour E, Sabaghi M (2020) Production and characterization of catechin-loaded electrospun nanofibers from Azivash gumpolyvinyl alcohol. Carbohydr Polym [Internet] 235:115979. Available from: https://www.sciencedirect.com/science/article/ pii/S0144861720301533

313. Padil VVT, Senan C, Wacfawek S, Lerník M (2016) Electrospun fibers based on Arabic, karaya and kondagogu gums. Int J Biol Macromol [Internet]. 91:299-309. Available from: https://www. sciencedirect.com/science/article/pii/S0141813016304755

314. Lubambo AF, Ono L, Drago V, Mattoso N, Varalda J, Sierakowski MR et al (2015) Tuning Fe3O4 nanoparticle dispersion through pH in PVA/guar gum/electrospun membranes. Carbohydr Polym [Internet] 134:775-783. Available from: http://europepmc.org/ abstract/MED/26428185

315. Zhang C, Feng F, Zhang H (2018) Emulsion electrospinning: Fundamentals, food applications and prospects. Trends food Sci; Technol [Internet] 80:175-186. Available from: http://europepmc. org/abstract/AGR/IND606120188

316. Wang W, Xue C, Mao X (2020) Radioprotective effects and mechanisms of animal, plant and microbial polysaccharides. Int J Biol Macromol [Internet] 153:373-384. Available from: https:// www.sciencedirect.com/science/article/pii/S014181302030876X

317. Lopes-da-Silva JA, Veleirinho B, Delgadillo I (2009) Preparation and characterization of electrospun mats made of PET/chitosan hybrid nanofibers. J Nanosci Nanotechnol 9(6):3798-3804

318. Chen H, Huang J, Yu J, Liu S, Gu P (2011) Electrospun chitosangraft-poly ( $\varepsilon$-caprolactone)/poly ( $\varepsilon$-caprolactone) cationic nanofibrous mats as potential scaffolds for skin tissue engineering. Int J Biol Macromol [Internet] 48(1):13-19. Available from: https:// www.sciencedirect.com/science/article/pii/S0141813010002990

319. Alavarse AC, de Oliveira Silva FW, Colque JT, da Silva VM, Prieto T, Venancio EC et al (2017) Tetracycline hydrochlorideloaded electrospun nanofibers mats based on PVA and chitosan for wound dressing. Mater Sci Eng C, Mater Biol Appl [Internet] 77:271-281. Available from: http://europepmc.org/abstract/ MED/28532030

320. Ashtikar M, Wacker MG (2018) Nanopharmaceuticals for wound healing - Lost in translation?. Adv Drug Deliv Rev [Internet] 129:194-218. Available from: https://www.sciencedirect. com/science/article/pii/S0169409X18300449

321. Wang X, Um IC, Fang D, Okamoto A, Hsiao BS, Chu B (2005) Formation of water-resistant hyaluronic acid nanofibers by blowing-assisted electro-spinning and non-toxic post treatments. Polymer (Guildf) [Internet] 46(13):48534867. Available from: https://www.tib.eu/de/suchen/id/ elsevier\%3Adoi 10.1016\%252Fj.polymer.2005.03.058

322. Naeimi A, Payandeh M, Ghara AR, Ghadi FE (2020) In vivo evaluation of the wound healing properties of bio-nanofiber chitosan/ polyvinyl alcohol incorporating honey and Nepeta dschuparensis. Carbohydr Polym [Internet] 240:116315. Available from: http://europepmc.org/abstract/MED/32475579
323. Séon-Lutz M, Couffin AC, Vignoud S, Schlatter G, Hébraud A (2019) Electrospinning in water and in situ crosslinking of hyaluronic acid / cyclodextrin nanofibers: Towards wound dressing with controlled drug release. Carbohydr Polym [Internet] 207:276-287. Available from: https://www.sciencedirect. com/science/article/pii/S0144861718314188

324. Chanda A, Adhikari J, Ghosh A, Chowdhury SR, Thomas S, Datta P et al (2018) Electrospun chitosan/polycaprolactonehyaluronic acid bilayered scaffold for potential wound healing applications. Int J Biol Macromol [Internet] 116:774-785. Available from: https://www.sciencedirect.com/science/article/ pii/S0141813018304008

325. Figueira DR, Miguel SP, de Sá KD, Correia IJ (2016) Production and characterization of polycaprolactone- hyaluronic acid/ chitosan- zein electrospun bilayer nanofibrous membrane for tissue regeneration. Int J Biol Macromol [Internet] 93:1100-1110. Available from: https://www.sciencedirect.com/science/article/ pii/S0141813016309382

326. García-Moreno PJ, Özdemir N, Stephansen K, Mateiu R V, Echegoyen Y, Lagaron JM et al (2017) Development of carbohydrate-based nano-microstructures loaded with fish oil by using electrohydrodynamic processing. Food Hydrocoll [Internet] 69:273-285. Available from: https://www.sciencedirect. com/science/article/pii/S0268005X16306713

327. Islam MS, Yeum JH (2013) Electrospun pullulan/poly(vinyl alcohol)/silver hybrid nanofibers: Preparation and property characterization for antibacterial activity. Colloids Surfaces A Physicochem Eng Asp [Internet] 436:279-286. Available from: https://www. sciencedirect.com/science/article/pii/S0927775713005578

328. Aguilar-Vázquez G, Loarca-Piña G, Figueroa-Cárdenas JD, Mendoza S (2018) Electrospun fibers from blends of pea (Pisum sativum) protein and pullulan. Food Hydrocoll [Internet] 83:173181. Available from: https://www.sciencedirect.com/science/artic le/pii/S0268005X18301498

329. Haghighatpanah N, Mirzaee H, Khodaiyan F, Kennedy JF, Aghakhani A, Hosseini SS et al (2020) Optimization and characterization of pullulan produced by a newly identified strain of Aureobasidium pullulans. Int J Biol Macromol [Internet] 152:305-313. Available from: http://europepmc.org/abstract/ MED/32088229

330. Tiwari S, Patil R, Dubey SK, Bahadur P (2019) Derivatization approaches and applications of pullulan. Adv Colloid Interface Sci [Internet] 269:296-308. Available from: http://europepmc. org/abstract/MED/31128461

331. Drosou C, Krokida M, Biliaderis CG (2018) Composite pullulan-whey protein nanofibers made by electrospinning: Impact of process parameters on fiber morphology and physical properties. Food Hydrocoll [Internet] 77:726-735. Available from: https:// app.dimensions.ai/details/publication/pub.1092621032

332. Blanco-Padilla A, López-Rubio A, Loarca-Piña G, GómezMascaraque LG, Mendoza S (2015) Characterization, release and antioxidant activity of curcumin-loaded amaranth-pullulan electrospun fibers. LWT - Food Sci Technol [Internet] 63(2):11371144. Available from: https://www.sciencedirect.com/science/article/ pii/S0023643815002340

333. Zhang Y, Kong H, Fang Y, Nishinari K, Phillips GO (2013) Schizophyllan: A review on its structure, properties, bioactivities and recent developments. Bioact Carbohydrates Diet Fibre [Internet] 1(1):53-71. Available from: https://www.sciencedirect. com/science/article/pii/S2212619813000053

334. Hamedi S, Shojaosadati SA, Najafi V, Alizadeh V (2020) A novel double-network antibacterial hydrogel based on aminated bacterial cellulose and schizophyllan. Carbohydr Polym [Internet] 229:115383. Available from: https://www.sciencedirect. com/science/article/pii/S0144861719310501 
335. Abdel-Mohsen AM, Abdel-Rahman RM, Fouda MMG, Vojtova L, Uhrova L, Hassan AF et al (2014) Preparation, characterization and cytotoxicity of schizophyllan/silver nanoparticle composite. Carbohydr Polym [Internet] 102:238-245. Available from: http:// europepmc.org/abstract/MED/24507278

336. Mousaviasl S, Saleh T, Shojaosadati SA, Boddohi S (2018) Synthesis and characterization of schizophyllan nanogels via inverse emulsion using biobased materials. Int J Biol Macromol [Internet] 120:468-474. Available from: https://www.sciencedirect. com/science/article/pii/S014181301832333X

337. Vashisth P, Srivastava AK, Nagar H, Raghuwanshi N, Sharan S, Nikhil K et al (2016) Drug functionalized microbial polysaccharide based nanofibers as transdermal substitute. Nanomedicine [Internet] 12(5):1375-1385. Available from: http://europepmc. org/abstract/MED/26964481

338. McCarthy RR, Ullah MW, Booth P, Pei E, Yang G (2019) The use of bacterial polysaccharides in bioprinting. Biotechnol Adv [Internet] 37(8):107448. Available from: https://www.sciencedirect.com/ science/article/pii/S073497501930148X

339. Kareem AJ, Abdul Sattar Salman J (2019) Production of Dextran from Locally Lactobacillus Spp. Isolates. Reports Biochem Mol Biol [Internet] 8(3):287-300. Available from: https://pubmed. ncbi.nlm.nih.gov/32274401

340. Sampaio ICF, Crugeira PJL, Soares LGP, dos Santos JN, de Almeida PF, Pinheiro ALB et al (2020) Composition of Xanthan gum produced by Xanthomonas campestris using produced water from a carbonated oil field through Raman spectroscopy. J Photochem Photobiol B Biol [Internet] 213:112052. Available from: https:// www.sciencedirect.com/science/article/pii/S1011134420305029

341. Maliri RI, Lesage J, Toncelli C, Fortunato G, Rossi RM, Spano F (2019) Crosslinking dextran electrospun nanofibers via borate chemistry: Proof of concept for wound patches. Eur Polym J [Internet] 110:276-282. Available from: https://www.sciencedirect.com/ science/article/pii/S0014305718307389

342. Martín-Alfonso JE, Cuadri AA, Berta M, Stading M (2018) Relation between concentration and shear-extensional rheology properties of xanthan and guar gum solutions. Carbohydr Polym [Internet] 181:63-70. Available from: https://www.sciencedirect. com/science/article/pii/S0144861717312134

343. Faralli A, Shekarforoush E, Ajalloueian F, Mendes AC, Chronakis IS (2019) In vitro permeability enhancement of curcumin across Caco-2 cells monolayers using electrospun xanthan-chitosan nanofibers. Carbohydr Polym [Internet] 206:38-47. Available from: https://www.sciencedirect. com/science/article/pii/S0144861718312761

Publisher's Note Springer Nature remains neutral with regard to jurisdictional claims in published maps and institutional affiliations. 